\title{
Gümő-specifikus NCR peptidek azonosítása, vad és mutáns Medicago truncatula gyökérgümők összehasonlító fehérjeanalízise, és az NCR247 lehetséges bakteriális interakciós partnereinek felderítése
}

\author{
Ph.D. értekezés
}

\section{Dürgő Hajnalka}

Témavezető: Dr. Medzihradszky-Fölkl Katalin

\author{
Biológia Doktori Iskola \\ MTA SZBK Biokémia Intézet \\ SZTE TTIK
}

Szeged

2015 
Rövidítések jegyzéke

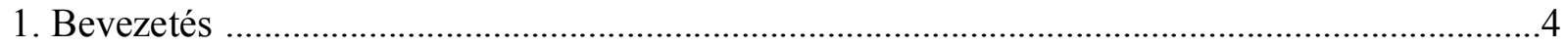

1.1. Témafelvetés, irodalmi áttekintés, biológiai háttér ................................................................4

1.1.1 Bakteroidok differenciálódása, gümö-specifikus növényi peptidek ................................. 11

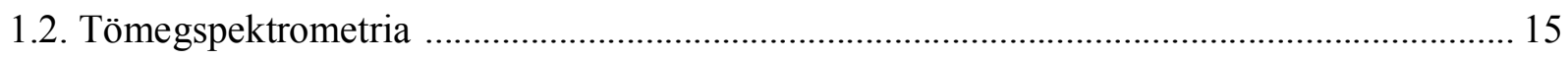

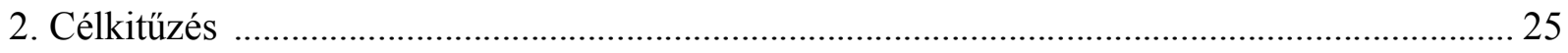

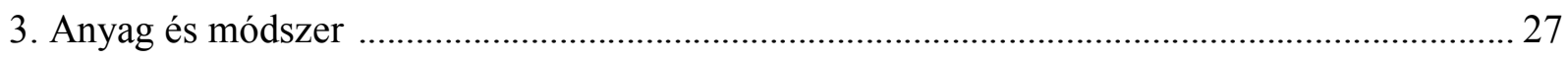

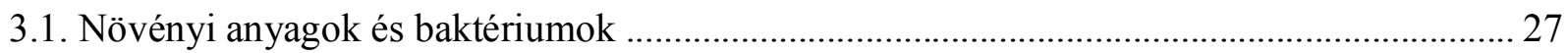

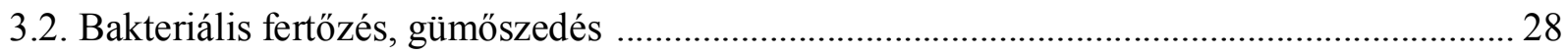

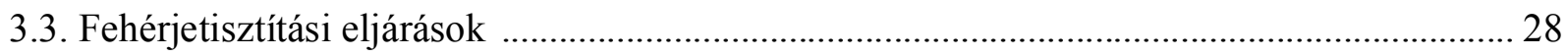

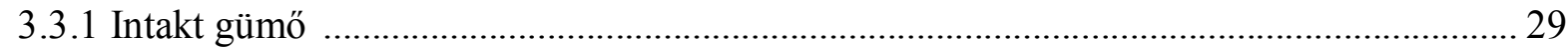

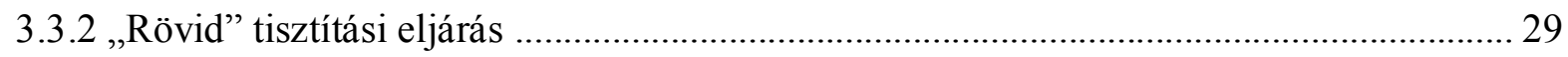

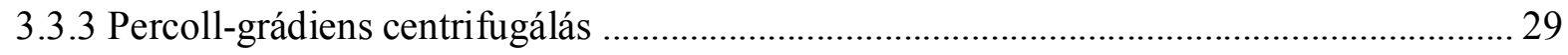

3.4 Bakteroidok feltárása ultrahangos szonikálással ............................................................... 30

3.5 A mintában lévő fehérjék hidrofóbicitás szerinti elválasztása ............................................. 30

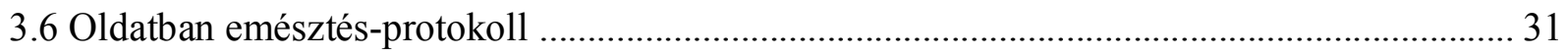

3.7 Coomassie brillant blue 1D SDS-PAGE gél minták emésztése protokoll .............................. 31

3.8 NCR247 peptid C-terminálisának megjelölése, affinitás-kromatográfia ................................ 32

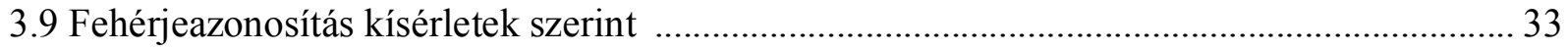

3.9.1 NCR-peptidek azonosítása M. truncatula A17 gümőiből kísérlet .................................... 33

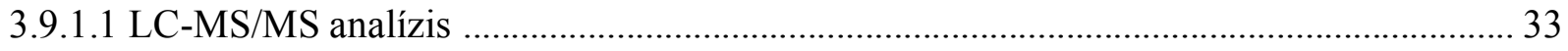

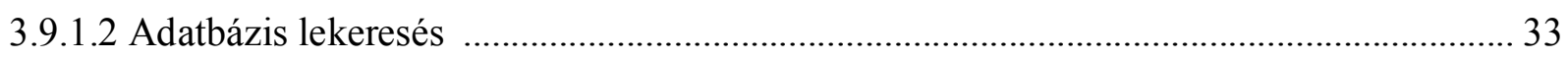

3.9.1.3 Peptidszintü összehasonlítás, fitXIC program, referencia-lista ....................................... 34

3.9.2 Medicago truncatula A17 vad és 6V mutáns peptidome összehasonlítása ....................... 36

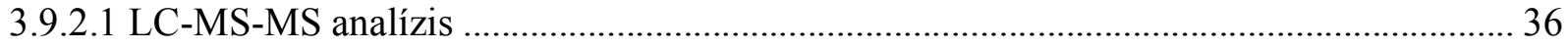

3.9.2.2 Relatív kvantitatív analízis spektrumszámlálással ........................................................ 36 
3.9.3.1 Mintaelőkészítés, emésztés, analízis, adatbázis lekeresés ........................................... 37

3.9.3.2 Anyagok és módszerek ismertetése kísérletenként .......................................................... 37

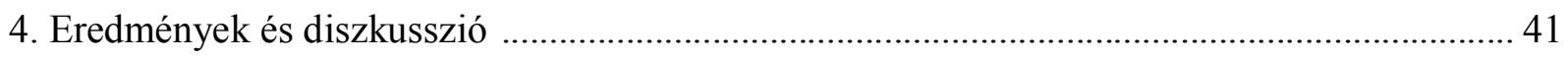

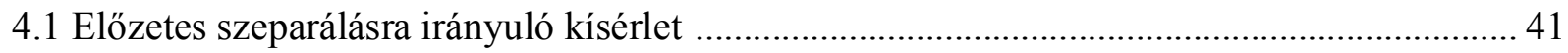

4.2 Intakt és tisztított gümők LC-MS/MS analízise, NCR peptidek azonosítása .......................... 42

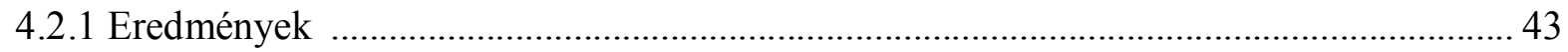

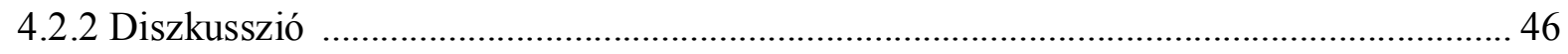

4.3 Vad és mutáns növényből származó gyökérgümők fehérjeszintű analízise, a minták fehérjetartalmának és NCR peptid tartalmának szemikvantitatív összehasonlítása ................................... 50

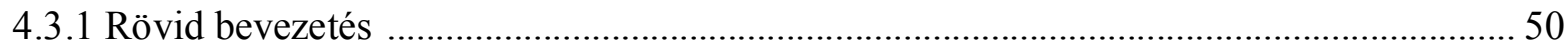

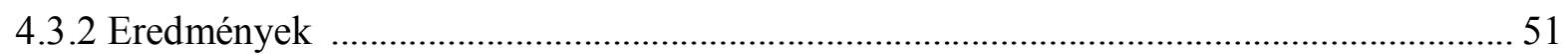

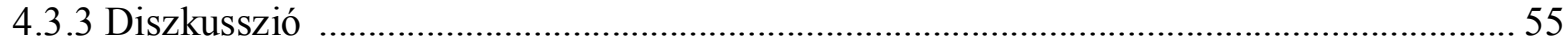

4.4 NCR247 növényi fehérje lehetséges kölcsönható partnereinek azonosítása Medicago truncatula A17 gümőkből izolált differenciálódott bakteroid mintákból ....................................... 57

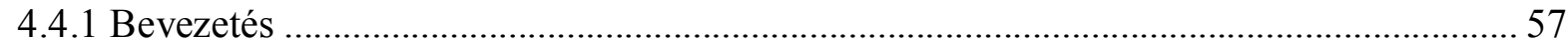

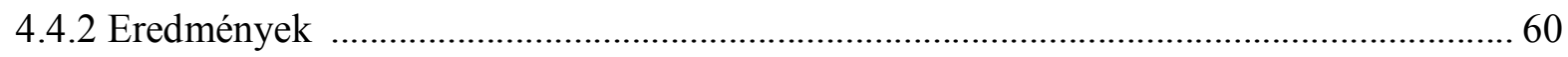

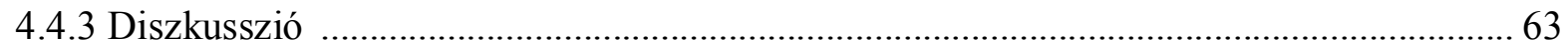

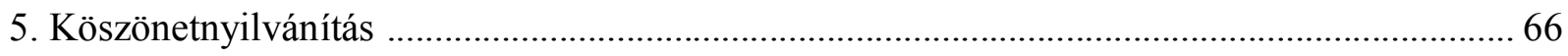

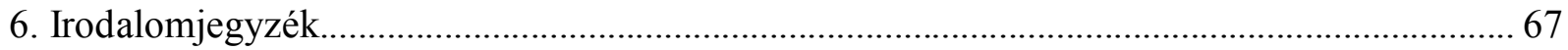

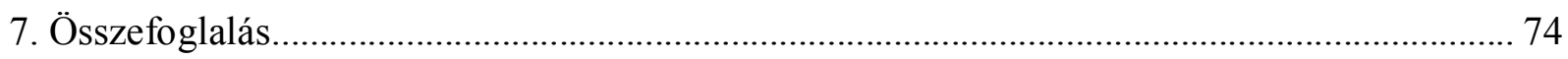

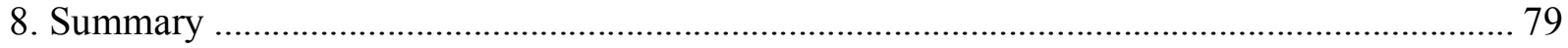

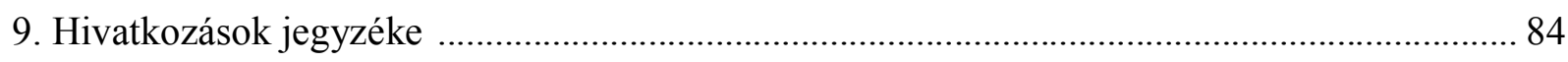

10. Függelék 


\section{Rövidítések jegyzéke}

ABC puffer: Ammónium-bikarbonát puffer

ACN: Acetonitril

DHB: dihidro-benzoesav

DTT: ditiotreitol

FA: hangyasav (formic acid)

FDR: Fals discovery rate

Fix-mutáns: nitrogénkötésre képtelen mutáns növény

GRP: glicin aminosavban gazdag fehérje (glicine-rich peptide)

HPLC: nagy hatékonyságú folyadékkromatográfia (High-performance liquid chromatography)

IAM: Jódacetamid

maximum peptid/protein E-value: mérőszám, mely megadja a maximális valószínüségét annak, hogy a lekeresés során véletlenszerüen kapok egy peptid/fehérje-találatot

minimum peptid/protein score: a peptid/fehérje elfogadáshoz szükséges minimum ponszám

NCR: nodule-specific cysteine rich peptide

Nod-faktorok: lipo-kito oligoszaccharid típusú bakteriális jelmolekulák

nsPEPs: gümő-specifikus növényi faktorok (=symPEPs: nodule-specific symbiotic peptides)

OD600: optikai denzitás 600 nm hullámhosszon

PBM: peribakteroid membrán

SNAP: kisméretü gümő-specifikus peptid (small nodule-specific peptide)

TCEP: trisz(2-karboxietil)foszfin-hidroklorid

TFA: trifluor-ecetsav

ULC-MS szolvens: Ultra LC/MS tisztaságú oldószer? 


\section{Bevezetés}

\subsection{Témafelvetés, irodalmi áttekintés, biológiai háttér}

Minden élőlény számára léteznek esszenciális elemek és vegyületek. Makro-elemeknek nevezzük azokat a tápelemeket, melyek nagy mennyiségben (0,1-6\%) fordulnak elő az élőlényekben. Ezek közé tartozik a nitrogén is, mely nitrogéngázként a levegő $78 \mathrm{v} / \mathrm{v} \%$-át alkotja, mégis ebben a formájában hozzáférhetetlen az élőlények nagy többsége számára. A növényvilágot tekintve a légköri nitrogén nitrogén bejut a növénybe, de a $\mathrm{CO}_{2}$-dal együtt távozik is belöle, megfelelő enzim hiányában nem képes hasznosulni. A növényeknek azonban, föként a virágzás utáni fejlődési fázisban a nitrogén-igényük nagyon jelentős. A talaj nitrogénformái közül a $\mathrm{NO}_{3}{ }^{-}$és az $\mathrm{NH}_{4}^{+}$a növények számára közvetlenül hozzáférhető. Amennyiben a talaj nitrátban és ammóniában szegény, úgy mütrágyákkal való pótlása, vagy a légköri nitrogén megkötése válik szükségessé. A levegö $\mathrm{N}_{2}$-tartalmát csak úgy képes a növényvilág többsége hasznosítani, ha azt valamilyen módon $\mathrm{HN}_{4}^{+}$ionná redukálva veheti magához. Ezt az átalakítást azonban mai ismereteink szerint csak bizonyos prokarióta fajok, a talajban vagy a vízben szabadon élő baktériumok, gombákkal szimbionta cianobaktériumok és a pillangós virágúakkal szimbiózisban élő baktériumok végzik. Nitrogénkötésre képes prokarióta fajokat három csoportba sorolhatjuk attól függően, hogy ezt a „feladatot” szabadon élő formájában, vagy növényekkel együttműködve, laza asszociációban vagy szimbiózisban együtt élve látja-e el [Oldroyd és Downie 2008; Sandal 2002]. Ezek a szimbiotikus kapcsolatok létrejöhetnek két vagy több faj között, ezek elsődleges célja tehát a kömyezeti tényezök hatékonyabb kihasználása a kapcsolatban résztvevő összes partner számára. Ezek a kapcsolatok az evolúció során több alkalommal és több élölénycsoportban is kialakultak [Falkowsky 1997, Boyd 2013], általában hosszú távra jönnek létre. A szimbiotikus kapcsolatban részt vevő mikrobiális szervezetek egy része szabadon élő formában is előfordulhat, a szimbiózist követően azonban a partnerek sok esetben elveszítik önálló életképességüket.

A növények megfelelö tápanyag-ellátottsága képezi az alapját a rájuk épülő társulások, és az egész biogeocönózis tápanyagforgalmának. Mivel tehát a levegő nitrogéntartalmának megkötése és a növények számára hozzáférhetővé tétele több szempontból is igen fontos biológiai folyamat, ezért a pillangós virágú növények és a velük szimbiózist kialakító baktériumok genetikai, genomikai kutatása mezőgazdasági, gazdasági és ökológiai jelentőségük következtében kimagasló támogatást és figyelmet élvez az utóbbi években. 
A Rhizobium-baktériumok aerob Gram-negatív baktériumok a gazdanövénnyel szimbiózisban élnek (föképp a Rhizobium, Bradyrhizobium és Azorhyzobium fajok). A kapcsolat mindkét partner számára elönyös, mert amíg a baktérium képes a légköri nitrogén megkötésére és ammóniává alakítására, így az felhasználhatóvá válik a pillangós virágúak, közvetetten pedig még több növény számára [Terpolilli 2012], addig a növény a fotoszintézisből származó szerves anyagokkal látja el szimbionta partnerét. A Rhizobium-baktériumok csak a pillangósokkal szimbiózisban, a gyökérgümőkben élve tudják a levegő nitrogénjét megkötni, mesterséges táptalajon és a talajban szabadon élő formában nem. A Fabaceae család körülbelül 20 ezer tagja közül még csak pár ezret vizsgáltak, de a vizsgált fajok 90\%-ánál találtak gyökérgümő-képzést, sőt, a nem pillangósok között is elöfordul a nitrogénkötés jelensége [Op den Camp 2011]. A Rhizobium fajok szimbiotikus kapcsolata magas szintü gazdaspecifitást mutat, hisz a Sinorhizobium meliloti például csak a Medicago, Melilotus és Trigonella fajokkal képez ilyen típusú kapcsolatot, más pillangós fajokkal nem.

A mikrobiális élőlények és gazdaszervezeteik közötti szimbiotikus kapcsolatok eredményezhetik egy új, a későbbiekben a szimbiózis folyamatának helyt adó szerv kialakulását. A Rhizobiumfajok a gazdanövény gyökerén hozzák létre ezt a sejtburjánzással keletkező „szervet”, a gyökérgümőt. Ebben történik a légköri nitrogén megkötése és ammóniává redukálása. A gümők belsejében membránnal körülzártan találhatóak az endoszimbionta életmódú, nitrogénkötést végző, átalakult Rhizobium baktériumok, melyeket bakteroidoknak nevezünk. A pillangós virágú növények és a baktériumok szimbiózisa soklépéses, bonyolult folyamat eredményeként alakul ki, melynek kiváltó oka a talaj alacsony $\mathrm{NH}_{4}{ }^{+}$szintje, azaz a növény nitrogén-éhsége. Ezek a baktériumok szabadon élő, szaprofita formában általánosan megtalálhatóak a talajban. Szimbiózis létrejöttekor a baktériumok bakteroidokká differenciálódnak, a bakteroid forma képes a légköri nitrogén megkötésére.

Számos kedvező genetikai tulajdonsága (kis genomméret, diploid, transzformálható) miatt a nitrogénfixáló szimbiotikus kapcsolat egyik modellnövénye a Medicago truncatula. Egynyári, lágyszárú növény, mely a kétszikűek osztályába (Dicotyledonae), hüvelyesek rendjébe (Fabales), pillangósok családjába (Fabaceae), azon belül a Medicago nemzetségbe tartozik. Fő elterjedési területe a Földközi-tenger vidéke, fontos mezőgazdasági növényként régóta tartják számon. A virágzata fürt, vagy fejecske („pillangós virág”), hüvelytermése ívesen hajlott, vagy 
csigavonalban felcsavarodott, gyakran tüskés. A levelek hármasan összetettek. Számos ökotípusa és genotípusa ismert, ezek egyike a Jemalong A17 (11. ábra).

\section{A bakteriális fertözés, a gyökérgümö kialakulása}

A fertőzés folyamatát ezért maga a növény, a gyökeréből kibocsátott flavonoid molekulákkal indítja el-melyeket magas kötött nitrogénszintnél is kibocsát, amikor a szimbiózis kialakulása gátolt-mintegy magához csalogatva a Rhizobium baktériumokat [Perret 2000, Mierziak 2014] (1. ábra).

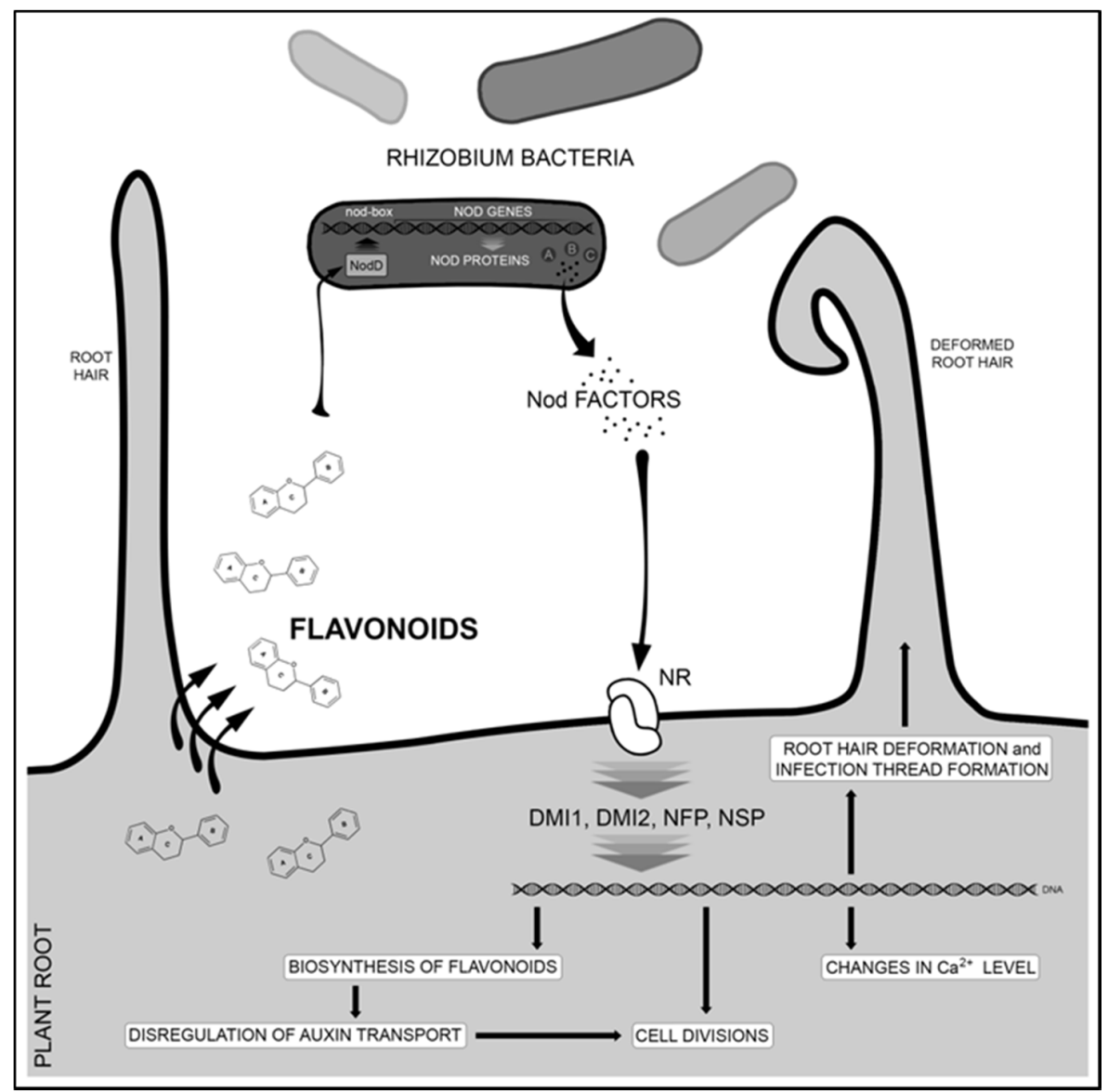

1. ábra: A falvonoidok szerepe és a bakteriális válasz (Mierziak 2014). NR: Nod-faktor receptor.

A flavonoid molekulák hatására a baktériumok pozitív kemotaxissal a gyökér felé vándorolnak, nodulációs génjeik indukálódnak, bakteriális jelmolekulákat, Nod-faktorokat termelnek és juttatnak a gyökérbe. Megkezdődik egy információ- és „szabályzóanyag” cserélő folyamat növény és prokarióta között. A nodulációs gének által kódolt Nod-fehérjék hatására gümőképző 
faktorok (Nod-faktorok) szintézise indul meg a baktériumban. A bakteriális Nod-faktorok a megfelelő receptorhoz kötődve a növényben eddig néma géneket aktiválnak, elöször a gyökér sejtjeiben, később a gümőben. Ezek (kémiailag lipochito-oligoszacharidok) egy kaszkádfolyamattal indukálják a gümőfejlődést, melynek kulcsszereplője a kalcium/calmodulindependens kináz enzim (CCaMK azaz DMI3). A Nod-faktorok bakteriális receptorai a korábbi, növény és gomba szimbiózisban részt vevő receptorokból alakultak ki az evolúció során. A vizsgált hüvelyes növények egy receptor-kináz pár, az NFR1/LYK3 és a NFR5/NFP által ismerik fel a bakteriális Nod-faktorokat, és ezen keresztül magát a Rhizobium baktériumot, valószínűleg bizonyos, a szignalizációs útvonalba tartozó receptorok specializálódása/fejlődése révén (kutatások sora bizonyította azt is, hogy a mikorrhízás és bakteriális szimbiózis folyamatai nagyon hasonló molekuláris alapokon nyugszanak). A Nod faktorok hatására aktiválódó jelátviteli útvonal az ún. nodulációs gének átíródását indítja be, amelyek bekapcsolásuk ideje szerint két csoportba sorolhatóak: a korai nodulin gének (Enod) a növény-baktérium kölcsönhatás kezdeti szakaszában, a késői (Late-nod) gének pedig a gümő kialakulását követően lépnek müködésbe [Kondorosi 2013]. A termelődő korai nodulinok hatására a növény gyökerének belső kéregsejtjei osztódni kezdenek, biokémiai és morfológiai változások indulnak meg a növényben, kialakulnak a gümö-primordiumok [Gibson 2008]. Ezzel párhuzamosan szintén a Nod-faktorok hatására kialakul az infekciós fonál, melyen keresztül a baktérium (peribakteroid membránnal körülvéve) a gyökérszőr mélyebb rétegeibe jut, míg el nem éri a gyökér-primordiumot (2. ábra).

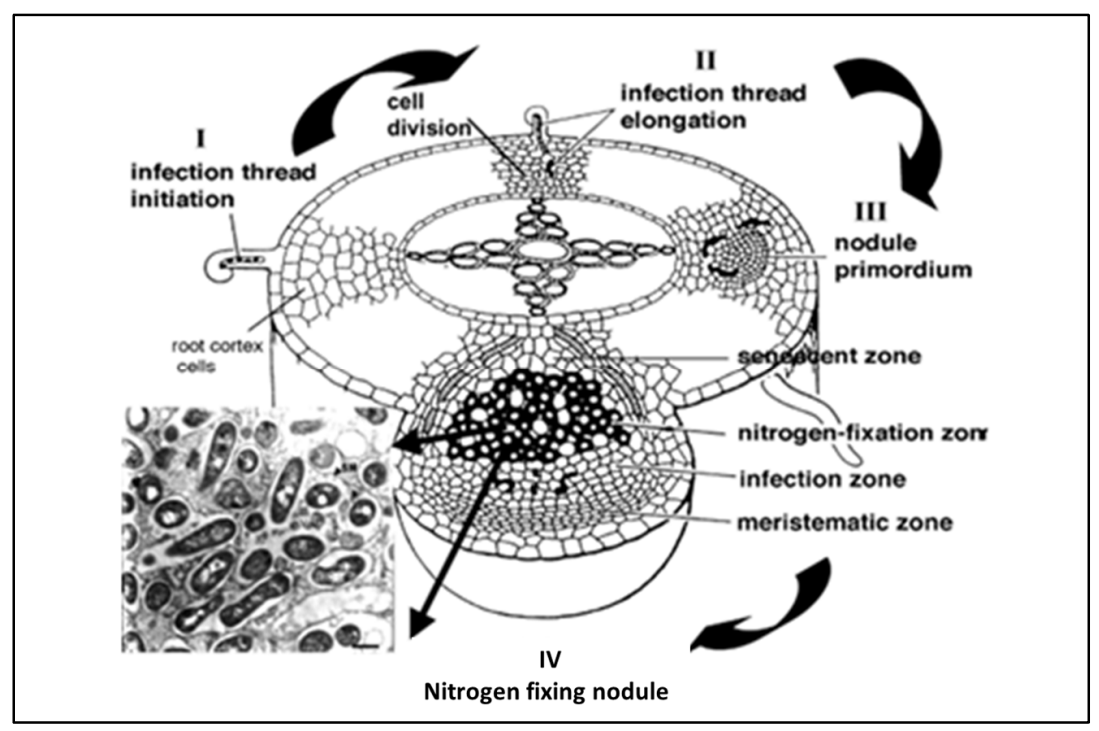

2. ábra: A gyökérgümő kialakulásának lépései (Medicago) 
A gyökér kéregsejtjeibe bejutott, elszaporodott baktériumok a belső kéreg citoplazmájába jutva sejtosztódást stimulálnak, e szövetburjánzás eredményei a kialakult gyökérgümők. A bakteriális fertőzés után néhány nappal már mikroszkóppal látható a fejlődő gümő. A növényi sejt belsejébe került baktériumokat növényi eredetű peribakteroid membrán veszi körül, ami igen fontos szerepet tölt be a gümőben. Speciális transzportfehérjéket tartalmaz, rajta keresztül nagyarányú anyagtranszport zajlik, mert a fertőzött sejtekben igen intenzív fehérjeszintézis és anyagcserefolyamatok történnek. A baktérium élettani folyamatai, anyagcseréje a növénnyel való "kommunikáció” kezdetétől átalakulóban van.

A pillangósok gyökérzetén létrejövő, sejtburjánzással keletkező gyökérgümők adnak helyt a légköri nitrogén megkötésének és redukálásának (3. ábra). Belsejükben membránnal körülzártan találhatóak az endoszimbionta életmódú, nitrogénkötést végző bakteroidok. A gümők jellegzetes rózsaszínes színét a bennük nagy mennyiségben megtalálható leghemoglobin adja. Ez a vegyület felelős a megfelelően alacsony oxigénszint fenntartásáért a gümőben, funkciója alapján az emlősök hemoglobinjához lehetne hasonlítani.

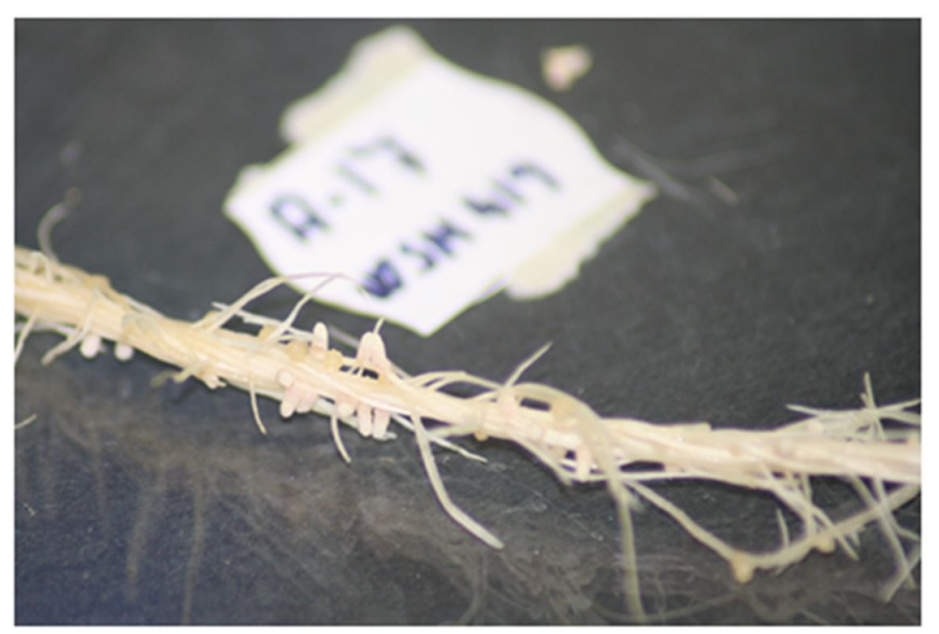

3. ábra: Medicago truncatula gümöi 


\section{A gyökérgümök típusai}

A gyökérgümők kialakulásának folyamata irrevezibilis, a folyamatok eredményeként kialakult gyökérgümőket két típusra oszthatjuk: determinált és indeterminált gümők típusára [Hirsch 1992. Gualtieri \& Bisseling 2000]. A determinált gümők jobbára a Glycine, Soya, Vigna nemzetségekhez tartozó trópusi hüvelyes növényekre, valamint a Lotus fajokra jellemzőek. Ezek a gümők a fertózés után röviddel elveszítik merisztematikus, azaz osztódási képességeiket, ettől kezdve csak sejtnagyobbodással nőnek. Az érett gümők a sejtmegnyúlásnak köszönhetően kerekdedek. A determinált gümőket képző növények másik csoportjában (ide tartozik például a földimogyoró) a noduláció nem gyökérszőrökhöz kötött. A determinált gümő szöveti felépítése nem mutat zonális tagolódást, belső részét teljes egészében a különböző korú nitrogénkötő bakteroidok töltik ki, az öregedő, szeneszcens bakteroidok régiója a gümő középső részén található [Popp \& Ott 2011].

A hüvelyes növények nagyobb része indeterminált gümőket képez, közéjük tartoznak a Pisum, Medicago, Trifolium és Vicia fajok. Ezekben a növényekben a fennmaradó aktív apikális merisztéma a gümő egész élete során új sejteket termel; a gümők megnyúlt, hengeres alakúak. Erre a gümőtípusra jellemző, hogy a gümő szöveti állománya zónákra különíthető (4. ábra): I. zóna a gyökértől legtávolabb eső gümő merisztéma (perzisztens apikális merisztéma), melyben nem találhatók bakteroidok. A II. zóna az infekciós zóna, ahol a sejtek differenciálódnak, és az infekciós fonálból az átalakulásban lévő bakteroidok a növényi sejtekbe jutnak. Ebben a zónában a növényi sejtek egymást követő endoreduplikálódása zajlik, melynek eredményeként a sejt DNS-állománya 2-től a 64-szeres mennyiséget is elérheti [Mergaert et al 2006]. A II. zóna disztális felén a baktériumok kijutnak az infekciós fonálból és kialakulnak a szimbioszómák (I. típusú bakteroidok). A további sejtosztódások eredményeképpen az I. típusú bakteroidok II. típusú, jellegzetes megnyúlt sejtalakkal rendelkező bakteroidokká alakulnak, melyek a II. zóna proximális régiójában koncentrálódnak [Kereszt et al, 2011]. A II. zóna disztális részén a baktériumok kiszabadulnak az infekciós fonálból és kialakulnak a szimbioszómák [Kereszt 2011]. A III. zónában mind a növényi sejtek, mind a baktériumok endoreduplikálódása megáll, ez a fixációs zóna, melyben a már teljesen differenciálódott (III. típusú) és a nitrogénkötésreátalakításra alkalmas működő bakteroidok (IV. típusú bakteroidok) találhatóak. IV. zóna az öregedési zóna, melyben a növényi sejtek és a bakteroidok is degradálódnak (csak elöregedett 
gümöben található). A II. és III. zóna közötti különálló részt interzónának nevezzük, ebben a zónában a legintenzívebb a bakteroidokká differenciálódás [Vasse 1990, Tiricz 2013].

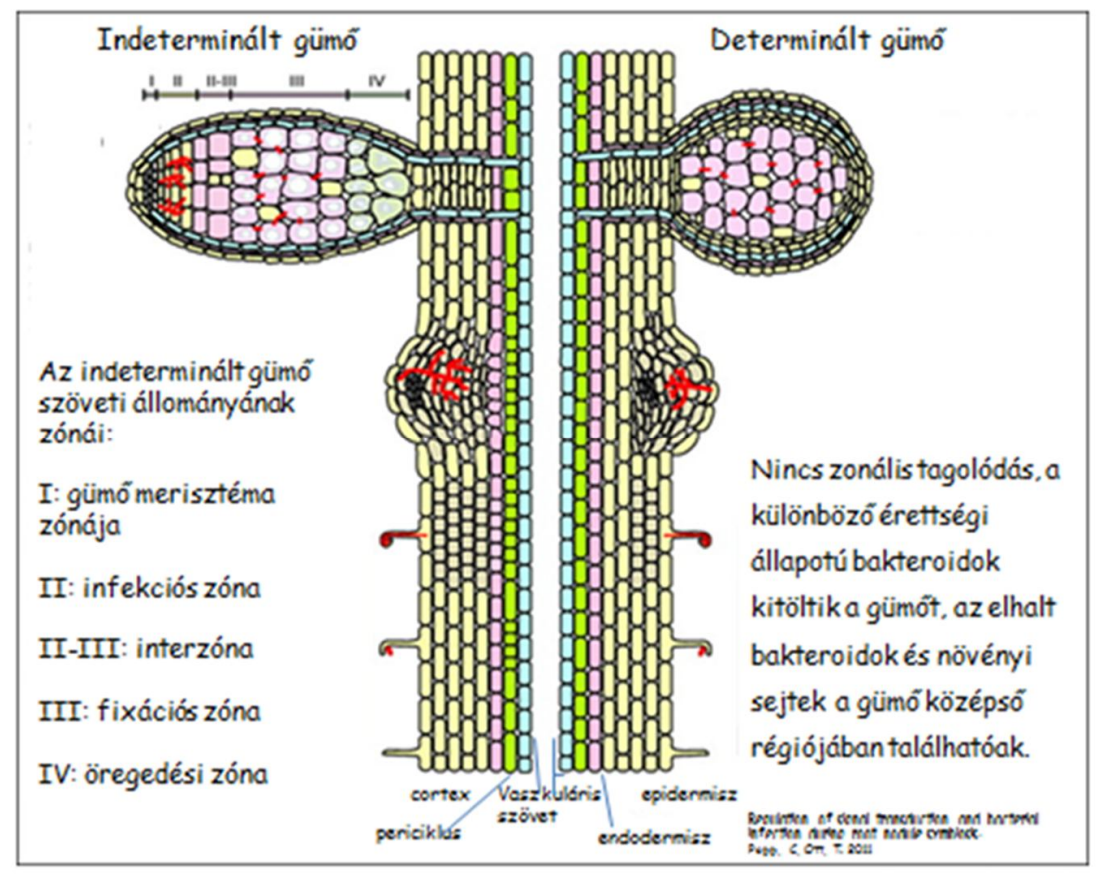

4. ábra: Determinált és indeterminált gümő zónái (Popp \& Ott 2011, Regulation of signal transduction and bacterial infection during root nodule symbiosis. Curr Opin Plant Biol. 2011).

Indeterminált gümök esetén tehát a III. zónában találhatóak a többszörös DNS-tartalmú, nitrogénkötést végző, teljesen differenciálódott bakteroidok, melyek a megnyúlt, esetenként Yformán elágazó sejtalakot vehetnek fel. Egy-egy szimbioszómában akár több ezer bakteroid is jelen lehet, a bakteroidok és a membrán közötti peribakteriális üregben a leghemoglobin nevü növényi fehérje található nagy mennyiségben, mely a bakteroidok szabályozott oxigénszállításáért felelős. Az oxigén szigorú szabályozásának oka, hogy míg a baktériumok légzéséhez elengedhetetlenül szükséges, túl nagy mennyiségben azonban inaktiválja a nitrogenáz enzimet (a nitrogenáz enzim két fehérjéből áll, egy Fe-proteinből és egy Fe-Mo-proteinből, ezek a fehérjék oxigén jelenlétében kicsapódnak), ezáltal gátolja a nitrogénkötés- és átalakítás folyamatát [Goldberg 1987]. 


\subsubsection{Bakteroidok differenciálódása, gümő-specifikus növényi pepetidek}

A korábbi vizsgálatok középpontjában az állott, hogy mely faktorok irányíthatják a baktériumok ilyen irányú átalakulását. Eme vizsgálatok arra világítottak rá, hogy a baktériumok átalakulását nagyobb mértékben indukálja és szabályozza a gazdanövény, mint a bakteriális genomban kódolt információk [Mergaert 2006, Bonaldi 2011]. A gümőfejlődés növényi gének százainak expressziójával jár együtt [Colebatch 2004, Benedito 2008]. A baktériumok metabolizmusában bekövetkező változások, amelyek megmutatkoznak a baktérium alakjában (megnyúlt, Y-forma) és méretében (5-10 $\mu$ m-es hossz) is, valójában a gazdanövénytől, a gazdanövény típusától függnek. A pillangós virágúak egy speciális csoportjánál, ahova a Medicago truncatula is tartozik (IRLC klád: Inverted Repeat Lacking Clade, ezekben a kloroplasztisz genom egyik fordított ismétlődése elvész), a szimbionta baktériumok differenciálódása genomjuk endoreduplikálódásával jár együtt. Ezt a genomi átalakulást követi a baktérium sejtalakjának megnyúlása és elágazása. Az így indukált bakteroid-differenciálódás kiváltó molekulái és irányítói növény által termelt gümőspecifikus növényi faktorok (Nodule-Specific Peptides, azaz nSPEPs vagy symPEPs). Ezek a fehérjék genomikai [Fedorova 2002, Mergaert 2003, Alunni 2007] és transzkriptomikai [Maunoury 2010, Roux 2014] vizsgálatok által is bizonyítottan a fertőzött gümősejtekben expresszálódnak, majd a bakteroidok citoplazmájába jutva felhalmozódnak [Vasse 1990, Mergaert 2003, Mergaert 2006, Alunni 2007, Van de Velde 2010, Bonaldi 2011, Haag 2011]. Az így kialakult bakteroidot az öt körülvevő növényi eredetü peribakteroid membránnal együtt szimbioszómának nevezzük. A fertőzött gümősejtekben expresszálódó, kisméretű fehérjék éretlen állapotban tartalmaznak egy N-terminális szignál szekvenciát, mely a szekréciós útvonalon az endoplazmatikus retikulumba (ER) irányítja a peptidet. A szignál szekvencia itt szignál peptidáz komplex hatására leválik az érett fehérjéről. A Medicago truncatula dnf-1 mutáns növényben a szignál peptidáz complex defektusa révén a szignál peptid lehasítása nem müködik, ́́gy ezek a fontos növényi peptidek nem válnak éretté és így képtelenek bejutni a szimbioszómába, ennek következtében elmarad a bakteroiddifferenciálódás [Wang 2010, Van de Velde 2010].

Az nsPEP-ek rendkívül nagy számban termelődnek a gümőben. Biokémiai jellemzőik alapján három nagy csoportba sorolhatjuk őket. A gümő-specifikus peptidek legkisebb csoportjába a

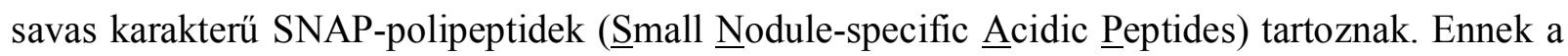


családnak eddig 8 tagját azonosították, oldalláncaik jellemzően savasak, méretük 10 kDa körüli ( 60 aminosav). A gümő-specifikus peptidek másik családjába a glicin-gazdag peptidek tartoznak (GRP, Glycine-Rich Peptides), EST adatbázisok és genomi szekvenciák alapján kevesebb, mint 30 tagját azonosították eddig [Kevei 2002, Mergaert 2003]. Érett polipeptidjeik körülbelül 100 aminosav hosszúságúak, nagy számban tartalmaznak glicint és bázikus aminosavakat.

A legnagyobb család a gümö-specifikus cisztein-gazdag peptidek (NCR, Nodule-Specific Cysteine Rich Peptides) családja, genomikai adatok alapján több mint 560 fehérje tartozik ide. Közös jellemzőjük, hogy viszonylag kicsik, 3-10 kDa közötti méretüek, az érett fehérjék (méretük miatt szokás peptideknek nevezni öket) általában 30-50 aminosav hosszúak, ehhez kapcsolódik még a 20-29 aminosavból álló szignál szekvencia az éretlen fehérjében. Az érett fehérjében 4 illetve 6 cisztein található konzervált elrendeződésben [Mergaert 2003] (3. ábra a-és b-motívum). A 4 ciszteint tartalmazó szekvenciákban a Cys 1 és Cys 2 között 5 aminosavat (X5), a Cys 3 és a Cys 4 között 4 aminosavat (X4) találunk; a 6 ciszteines motívumban Cys 1 és Cys 2 között 5 aminosav van, Cys 3 és Cys 4 között 4 aminosav, a Cys 4 -et 1 aminosav (X1) választja el a Cys 6-tól. Az ötös számú cisztein mindkét oldalán az aminosavak száma nem szigorúan meghatározott $(\mathrm{Xn})$.

NCR a-motívum: Szignál peptid-Xn-C1-X5-C2-Xn-C5-Xn-C3-X4-C4-X1-C6-Xn NCR b-motívum: Szignál peptid-Xn-C1-X5-C2-----Xn----C3-X4-C4-Xn

5. ábra: NCR peptidek 4 illetve 6 ciszteint tartalmazó motívumai (Mergaert 2003)

A peptidekben lévő szekvencia-különbségek eredményeként izoelektromos pontjuk 3-11 között változhat, tehát kationos ( $\mathrm{pI}>8)$, semleges $(\mathrm{pI} 6-8)$ és anionos $(\mathrm{pI}<6)$ karakterüek egyaránt vannak közöttük. Annak ellenére, hogy szekvencia-homológiát nemigen mutatnak más peptidekkel, szerkezetük alapján hasonlítanak növényi antimikrobiális peptidekhez, defenzinekhez. Kísérletek alapján úgy tünik, hogy baktériumokkal szembeni toxikus hatásukat leginkább anionos vagy kationos mivoltuk befolyásolja [Tiricz 2013, Farkas 2014]. A gümőspecifikus peptidek általunk vizsgált legnagyobb csoportja tehát szerkezeti hasonlóságot mutat a növényi defenzinekkel. A szerkezeti hasonlóságból kiindulva további in vitro vizsgálatokból kiderült, hogy több NCR peptid rendelkezik antimikrobiális hatással különböző Gram-negatív vagy Gram-pozitív 
baktériumokon, a Sinorhizobium melilotin kívül például Listeria monocytogenes, Enterococcus faecalis vagy Escherichia coli fajokon és különböző patogén gombafajokkal szemben [Tiricz 2013, Farkas 2014, Ördögh 2014]. A kationos NCR-peptidek célpontjai föként a bakteriális membránban találhatóak, míg az anionos NCR-ek a bakteroid citoplazmájában halmozódnak fel. Az NCR-ek egyrészt azáltal fejtik ki antimikrobiális hatásukat, hogy átjárhatóvá teszik a baktériumok sejtmembránját, gátolva azok légzését és szaporodását, lehetséges intracelluláris célpontjaiknak pedig főként a sejtosztódásban szerepet játszó fehérjék bizonyultak. Az anionos NCR-peptidek toxikus hatásáról egyelöre még nincsenek konkrét bizonyítékok, a kationos peptidekkel együtt hatva a bakteriális differenciálódás indukálásában, szabályozásában és a nitrogén fixálás folyamatában lehet szerepük. Az NCR fehérjék egyéni szerepe tehát még nem tisztázott, a bakteriális sejtosztódást gátló hatásuk azonban már bizonyított [Van de Velde 2010]. E hatás eredményeként a baktérium DNS-tartalma a sokszorosára növekszik, míg az ezt követő sejtosztódások nem következnek be, kialakul a poliploid bakteroid.

Mindhárom fehérjecsaládra jellemző, hogy kódoló génjeik kevés kivétellel kizárólag a fertőzött gümőkben expresszálódnak. A gümőspecifikus gének expressziós mintázata igen sokféle lehet, bizonyos gének a gümőfejlődés korai szakaszában fejeződnek ki, míg mások a későbbi időszakban, esetenként a fejlődő és a már működő gümőben is aktívak (Függelék 1. táblázat) [Kevei 2002, Mergaert 2003, Nallu 2013]. Az NCR-peptideket kódoló gének aktivitásuk alapján két nagy csoportba sorolhatóak: korai és késői gének csoportjába. A korai kifejeződésű gének a fertőzést követő néhány napban már aktívvá válnak. A korai gének egy részének fehérjetermékei érett állapotban az I. típusú bakteroidok endoreduplikációját segítik [Van de Velde et al, 2010], a korai gének másik része a fertőzést követő első hét végén expresszál. A késői NCR-gének a fertőzést követő 10-14. napon expresszálnak.

\section{A gyökérgümö müködése}

A gyökérgümő feladata tehát a légköri nitrogén megkötése és redukálása. Az $\mathrm{N}_{2}$ ammóniává redukálásának kulcsmolekulája a nitrogenáz enzimkomplez, mely két fehérjéből áll, egy Feproteinből és egy Fe-Mo-proteinből. A bakteroidokat tartalmazó sejtekben csökkentett oxigénszint uralkodik, ez elegendő a növényi sejt és a bakteroidok légzéséhez, és még a nitrogenáz enzim müködését sem gátolja. Az oxigénszállításért felelős leghemoglobin szintézise közös, a globin részt a növény, a hemet a baktérium állítja elő. A nitrogénfixálás folyamata nagy 
energiabefektetéssel jár, mert a két nitrogén-atom közötti hármas kötés bontása sok energiát igényel, emiatt a nitrogénkötő gümők csak nitrogénhiányos állapotban fejlődnek ki.

Az utóbbi években több tudományos cikk is szólt a szimbiótikus gyökérgümők transzkriptomikai [Maunoury 2010, Roux 2014] és proteomikai analíziséről [Rose 2012, Volkening 2012], de az NCR-peptidek fehérjeszinű kimutatására ezelőtt még nem került sor. Egyedül Van de Velde és munkatársainak 2010-ben megjelent cikke írja le öt NCR-peptid azonosítását, amelyet szintén az MTA SzBK Proteomikai Kutatócsoportja végzett. Valószínű, hogy az NCR peptidek nagy számban azért nem kerültek eddig azonosításra, mert kis méretük miatt a kísérletekben alkalmazott 1D vagy 2D-gél elektroforézis során a peptidek “elveszhettek” a mintákból. Ezt alátámaszthatja az a tény is, hogy egyéb, kis tömegü növényi vagy bakteriális eredetü fehérjéböl is csak keveset sikerült ezekben a kísérletekben azonosítani [Rose 2012, Volkening 2012]. 


\subsection{Tömegspektrometria}

A tömegspektrometria egy objektív analitikai módszer, melynek során a vizsgálandó anyagok molekulatömegeit mérjük. Viszonylag hosszú múltja ellenére a módszer csak az utóbbi néhány évtizedben, a technika fejlődésének hála vált általánosabbá biopolimerek vizsgálatára.

A tömeg egy molekula egyértelmüen meghatározható tulajdonsága, elegyek analízise során nem kell elöre ismernünk a keverék összetételét. Ahhoz, hogy molekulák tömegét megmérhessük szortírozható/szétválasztható állapotba kell hoznunk őket. Erre az anyagok ionizálása ad lehetőséget, mert elektromos vagy mágneses térben az ionok tömeg/töltés $(\mathrm{m} / \mathrm{z})$ alapján szortírozhatóak.

A 6. ábrán a tömegspektrométer általános felépítése látható.

\section{Mintabevitel}

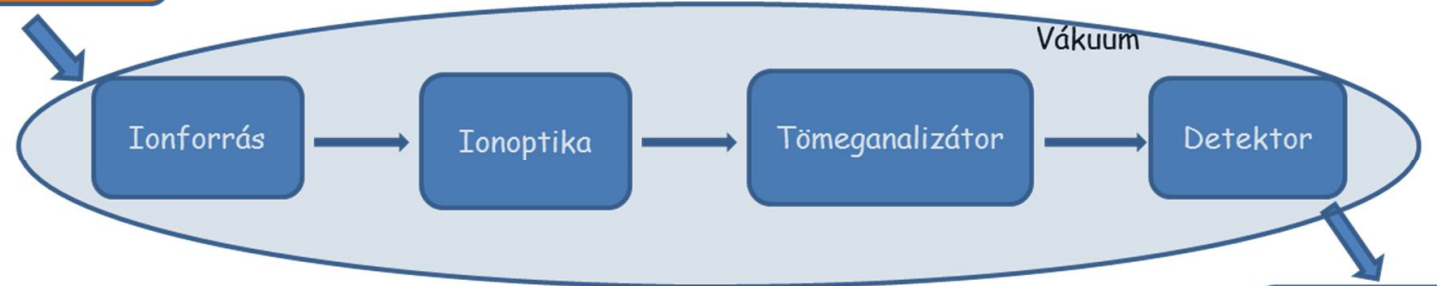

Adatfeldolgozás

6. ábra. A tömegspektrométer általános felépítése, egységei

Az ionizáció során az ionforrásban a vizsgálandó molekulákból vagy atomokból valamilyen gerjesztő energia segítségével (elektromos, lézer, stb) ionokat, azaz töltött részecskéket hozunk létre. Készülékektől függően az ionforrás lehet légköri nyomáson (API, Athmospheric Pressure Ionization) vagy vákuum alatt. Viszont az ion-keverék analízise minden esetben nagy vákuumban történik.

A tömegspektrometria korai időszakában azok az anyagok voltak így mérhetőek, melyeket bele tudtak párologtatni az ionforrásba, a képződött ionokat eztán elektromos feszültséggel röppályára küldték és mágneses vagy elektromos térrel szétválogatták őket. Az ionizációt nagyenergiájú elektronokkal végezték (elektron-impakt, EI), s a képződött ionokat megfelelő gyorsító 
feszültséggel irányították az analizátorba. Érdekes, hogy bár az ionizációt negatív töltésű részecskékkel végezzük, mégis inkább pozitív ionok képződnek. A negatív ionok képződése mindig rosszabb hatásfokú. Ez minden ionizációra érvényes, így a továbbiakban pozitív ionokról tárgyalunk. Ezzel a módszerrel azonban biológiai minták (kevés kivételtől eltekintve) nem voltak mérhetőek, mert a peptidek, cukrok elbomlanak párolgás helyett.

A kényes biológiai makromolekulák vizsgálatának problémáját az úgynevezett „lágy ionizációs technikákkal" oldották meg, melyek már lehetővé tették biopolimerek, nagyméretű szerves molekulák vizsgálatát. Ezek közé a technikák közé tartozik a gyors atom bombázásos ionizáció (FAB, Fast Atom Bombardment Ionization, amit csak történeti okokból említünk itt meg), a MALDI (Matrix Assisted Laser Desorption Ionisation, mátrixszal segített lézer-deszorpciós ionizáció) és az elektroporlasztásos (electrospray) ionizáció (ESI). Alapvető különbség az EI és a lágy ionizációs módszerek között, hogy míg az előbbiben gyökion képződik, amely a felvett energia-többlet hatására fragmentálódik, C-C kötések is könnyen hasadhatnak, addig a lágy ionizáció kvázi-molekula ion(oka)t, $\left[\mathrm{MH}_{\mathrm{n}}\right]^{\mathrm{n}+}$ eredményez, ESI-ben gyakran $\mathrm{n}>1$.

MALDI ionizáció: a vizsgálandó mintát a megfelelő UV-sugarat elnyelő $\left(\mathrm{N}_{2}\right.$ lézer, $\left.337 \mathrm{~nm}\right)$ mátrix anyaggal (például 2,5-dihidroxi-benzoesavval vagy $\alpha$-ciano-4-hidroxi-fahéjsavval) vegyítve visszük fel a minta-lemezre, erre rászárítjuk, így kristályos szerkezet képződik. Az ionizáció folyamán a lézerrel a mátrix anyagát gerjesztjük, mely plazma-állapothoz hasonlóan gomolyog a minta felett, protont ad át a mintának. Ennek eredményeként többnyire egyszeresen töltött ionok képződnek. Ezt az ionizációt többnyire repülési idő méréséhez kötik (Time-of-Flight analizátor, TOF). A módszer előnye, hogy egyszerü, gyors, nincs kereszt-szennyezés, igen nagy molekulák is (akár több mint $300 \mathrm{kDa}$ ) nagy érzékenységgel vizsgálhatóak vele, hátránya azonban, hogy kromatográfiához nem kapcsolható, és diszkriminatív, azaz nem megjósolható, hogy mely komponenseket látunk egy keverékből.

Az ESI eredményeképpen a mintából többszörösen töltött ionok keletkezhetnek. A vizsgálandó vegyületet megfelelő oldószerben feloldjuk, majd egy nagyfeszültségre kapcsolt kapillárison keresztül porlasztva juttatjuk az analizátorba az vizsgálandó vegyület ionjait (7. ábra). A folyamatban először többszörösen töltött cseppek képződnek, az oldószer molekulákat eltávolíthatjuk inert gázárammal vagy fütött kapillárissal már a készüléken belül. 


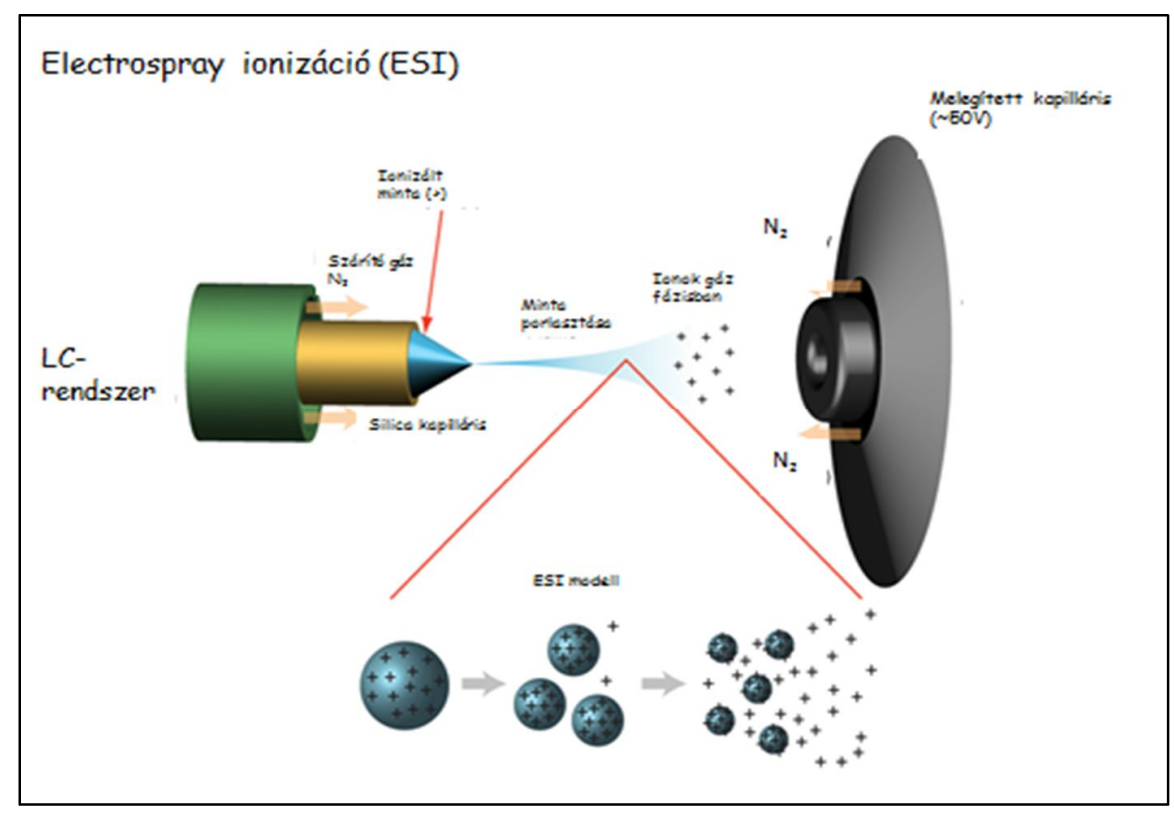

7. ábra: Electrospray ionizáció (www.lamondlab.com)

A dolgozatban bemutatott munka során többnyire ESI-t használtunk. Az ESI elönyei, hogy HPLC-rendszer detektoraként alkalmazható, a többszörösen töltött ionok miatt a vizsgálható tömegtartomány „kitágul”, keverékekből frakcionálás nélkül is több komponens detektálható, azaz nem annyira diszkriminatív, mint a MALDI.

Az ionok szétválasztása az analizátor részben m/z alapján történik. Itt tisztáznunk kell néhány alapfogalmat. A tömegfelbontás (R) megadja, hogy két iont mekkora tömegkülönbséggel tudunk egymás mellett detektálni. $\mathrm{R}=\mathrm{m}$ /delta $\mathrm{m}$. Manapság a legtöbb kutatásra alkalmas tömegspektrométer rendelkezik akkora felbontással, hogy az elemi izotópokat is meg tudjuk különböztetni (8. ábra). Az egy molekulát képviselö ioncsoportban az első izotóp csúcsot monoizotópos csúcsnak nevezzük, mert ebben csak egyféle izotóp van jelen. A fehérjealkotók (C, H, N, O, S esetleg P) esetén ez az ion a mintában jelen lévő kémiai elemek legnagyobb természetes gyakorisággal előforduló izotópját tartalmazza. Kisebb peptideknél a monoizotópos csúcs a legintenzívebb csúcs, míg molekula növekedésével a ${ }^{13} \mathrm{C}$ izotópok hozzájárulása növekszik, és a monoizotópos csúcs lassacskán „eltűnik”. A monoizotópos tömeg biztosítja a legnagyobb pontosságot, mert itt nem keverék iont mérünk. A tömegmérés pontosságát standard anyagokkal történő kalibrációval igyekezünk biztosítani, megadhatjuk a mérés hibáját abszolút 
tömegkülönbségekben, de sokkal pontosabb definíciót jelent, ha a hibát a mért m/z értékhez viszonyítjuk és ppm értékekben fejezzük ki.

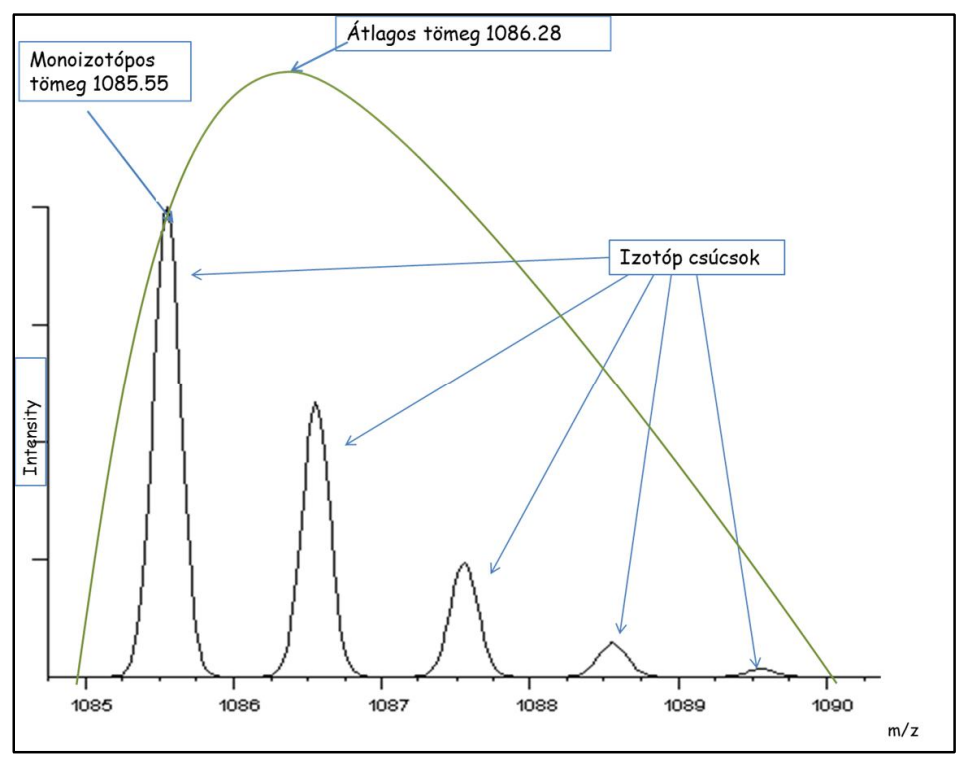

8. ábra: Illusztráció a nagy és kis felbontású tömegmérésre.

Az analizátor típusa lehet:

- Elektrosztatikus (ESA) és mágneses (B) analizátor - szektoros készülékek

- Kvadrupól analizátor (Q)

- Ioncsapda analizátor (trap)

- Repülési idő analizátor (TOF)

- Lineáris ioncsapda analizátor (LIT)

- Fourier-transzformációs ion ciklotron rezonancia MS (FT-ICR)

- Orbitrap (LTQ-Orbitrap Elite tömegspektrométer, 9. ábra)

Értekezésemben csak azokat az analizátorokat ismertetem, amelyekkel dolgoztunk.

Ioncsapda analizátor

Az ioncsapdába belépő ionok mozgását az elektródákra kapcsolt egyen- illetve váltófeszültség határozza meg. A 3 dimenziós ioncsapda két, egy belépő és egy kilépő hiperbolikus elektródából, 
valamint a közöttük elhelyezkedő gyürüelektródából áll. A középső gyürűelektródára helyezett egyen- és váltóáram hatására az ionok oszcilláló mozgást végeznek. Az összes ion egyszerre tartózkodik a csapdában, ahonnan adott $\mathrm{m} / \mathrm{z}$ alapján jutnak tovább a detektorba. Elönyei a nagy érzékenység, kis méret, és tandem tömegspektrometriás tulajdonságai $\left(\mathrm{MS}^{\mathrm{n}}, \mathrm{n}=\right.$ elméletileg 10$)$.

Orbitrap analizátor

Az orbitrap analizátor egy három elektródából felépülő elektrosztatikus ioncsapda. Két, hordó formájú elektróda között található az orsó alakú harmadik elektróda. A külső elektródák közötti apró résbe injektálják be az ionokat. Az orsó formájú elektródára néhány $\mathrm{kV}$ feszültséget kapcsolnak, a külső elektródák földelést kaptak. Az orbitrap-ben a keringő ionok összeütközését elkerülendő folytonos polaritásváltás (váltófeszültség) zajlik. A beinjektált ionok a belső elektród körül spirális mozgást ( $\mathrm{m} / \mathrm{z}$ szerint körpályán) végeznek. Az ionok oszcilláló mozgásának következtében a belső elektromos tér változik (kívülröl lehet detektorokkal mérni és követni), ezt a készülék Fourier-transzformációval frekvencia és intenzitás mennyiségekké alakítja át. Az orbitrap analizátorral igen nagy felbontást és nagy pontosságot lehet elérni.

Az Orbitrap Elite tömegspektrométer valójában egy hibrid készülék, melyben egy érzékeny, de kis felbontású ioncsapda és egy érzékeny, nagy pontosságú és nagy felbontású orbitrap kapott helyet (9. ábra). Kutatásaink során elsősorban ezzel a tömegspektrométerrel dolgoztunk.

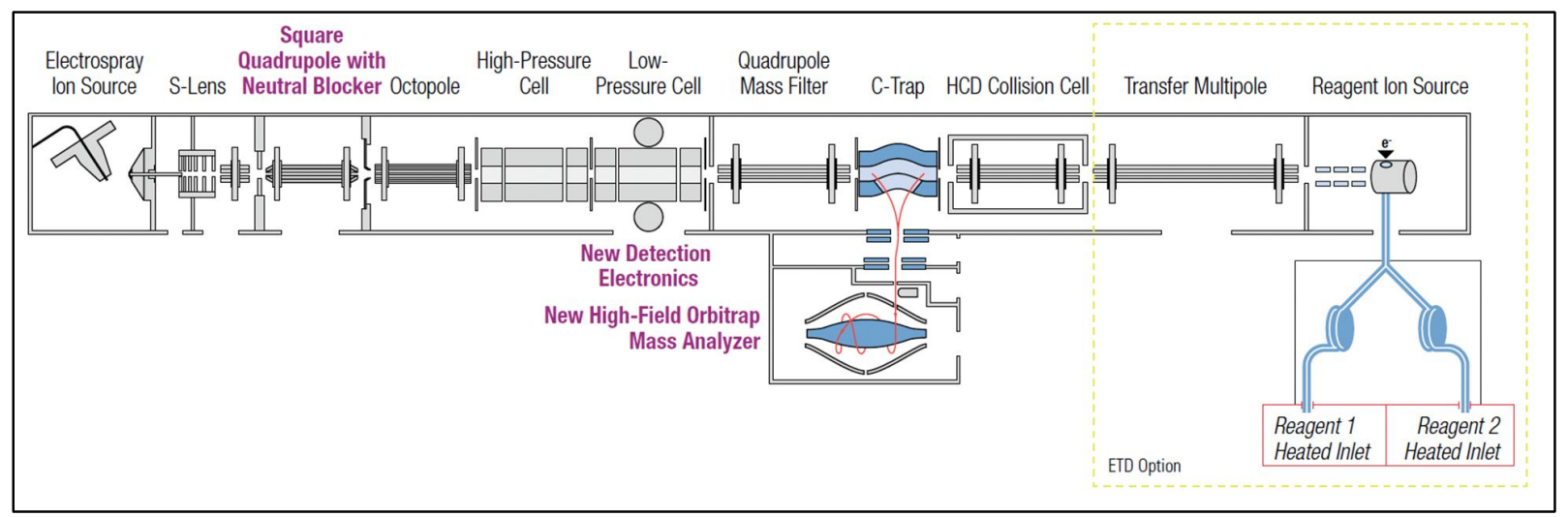

9. ábra: az Orbitrap Elite Hybrid MS felépítése (www.planetorbitrap.com)

Mint fentebb leírtam, a lágy ionizációs technikák protonált molekulaiont eredményeznek, az ion tömegének meghatározása azonban nem elegendő a pontos szerkezet-meghatározáshoz. A tömegmérést követően úgy kaphatunk a molekula szerkezetéről információt, ha a molekulaiont 
semleges gázzal ütköztetve darabokra törjük, ez ütközéses aktiválással kiváltott disszociáció, azaz collision-induced dissociation (CID). Egy tömegspektrumban mindig több komponens van jelen. Tehát valamilyen módon el kell különítenünk a bennünket érdeklő komponenst. Ennek megoldására jött létre a tandem tömegspektrometria. A válogatás lehet időbeli vagy térbeli. $\mathrm{Az}$ ioncsapda időben válogat, az összes iont beengedi, majd a feszültség szabályozásával benntartható az az ion, amely bennünket a továbbiakban érdekel. Az aktíválás és a darabok, azaz fragmensek mérése is a csapdában történik. A „valódi” tandem készülékeknél az első tömegspektrométer elkülöníti a megfelelő prekurzor iont, majd megtörténik az aktiválás és a második készülék méri a fragmenseket.

A dolgozatban ismertetett kísérletek során végig ioncsapda CID aktiválást alkalmaztunk. A CID spektrumok esetén kapható lehetséges fragmensek nagyon sok paramétertől függenek. Amennyiben a töltés a peptid N-terminálisán marad, akkor a peptidkötés hasadási helyétől függően $a$ és $b$ fragmenseket (ionokat) kapunk, C-terminálison visszamaradó töltés esetén $y$ fragmenseket (10. ábra A, B) [nomenklatúra: Biemann 1990, szabályok: Medzihradszky \& Chalkley 2015]. A fragmenseket a megfelelő terminustól számozzuk. Itt kell megjegyezni, hogy az ioncsapda CID tulajdonképpen rezonancia-aktiválás, azaz egy adott $\mathrm{m} / \mathrm{z}$ tartományra müködik, tehát egyetlen kötés hasadása után a folyamat leáll, mert a termék már ezen a tartományon kívül van. Ammónia- és vízvesztés viszont megfigyelhető úgy a prekurzor ionból, mint a fragmensekből.

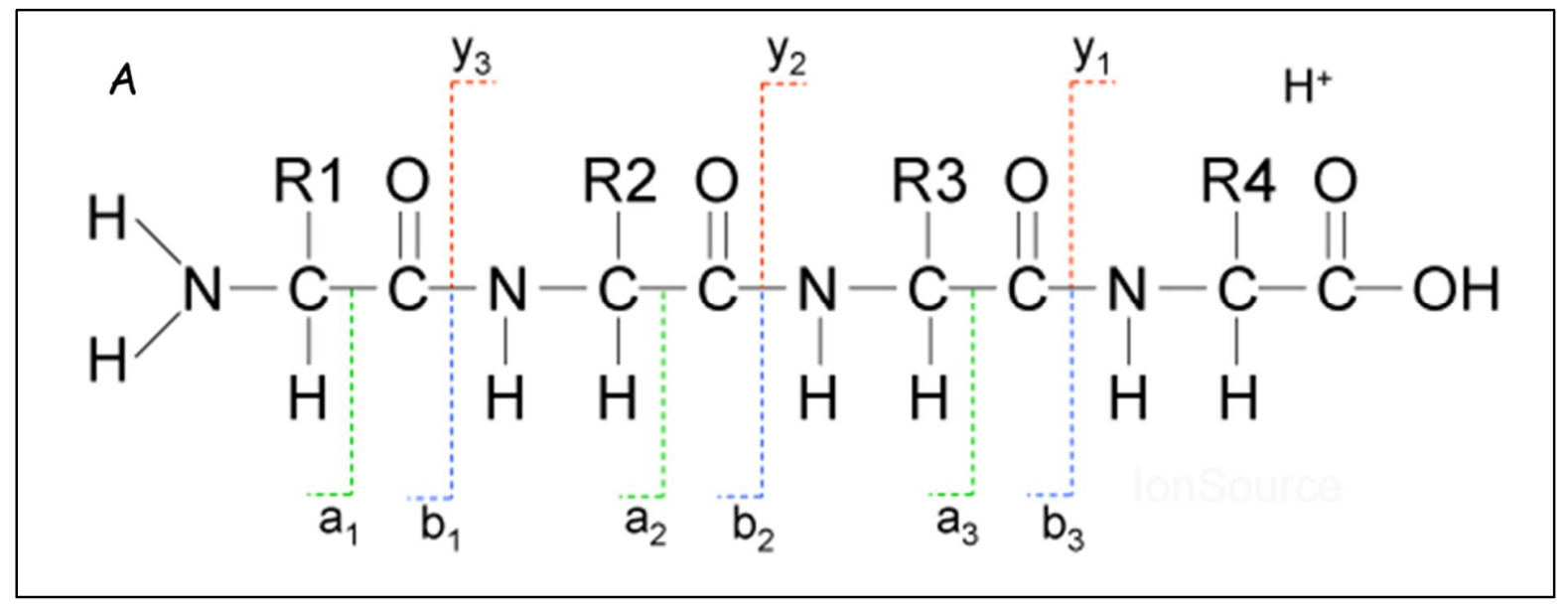




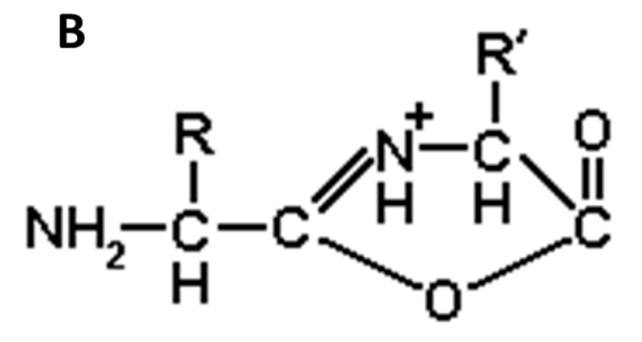

$b$ ion

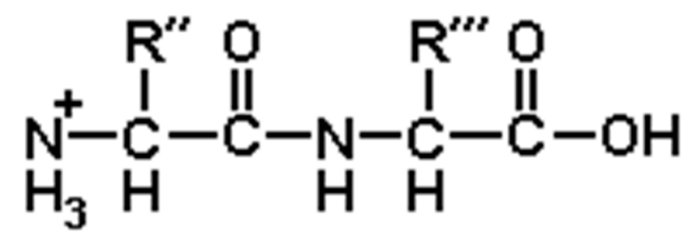

$y$ ion

10. ábra: egy példa szekvencia elméleti fragmensei (A, www.ionsource.com) és a $b$ és $y$ fragmensek általános szerkezete $(\mathrm{B}, \mathrm{www} . w e d d s l i s t . c o m)$

Az ioncsapdában végzett CID analízis, tulajdonképpen a céltömeg (kiválasztott $\mathrm{m} / \mathrm{z}$ ) rezonanciaaktiválása egy gondosan beállított rf "lökéssel”. Ez a rezonancia-aktiválás úgy van optimalizálva, hogy a legalacsonyabb tömegű fragmensek nem detektálhatók, így kb. a prekurzor m/z értékének alsó harmadát elveszítjük [Jonscher 1997].

A komplex peptid-elegyeket már régóta on-line LC/MS/MS módszerrel analizáljuk. Ennek során a HPLC frakcionálás közbeni adatgyüjtés automatikus. A készüléket irányító számítógép jelöli ki megadott paraméterek alapján a fragmentálódó prekurzor ionokat, a tömegméréseket egy vagy több MS/MS analízis követi. Annak érdekében, hogy minél több komponens azonosítható legyen, használjuk a dinamikus kizárás elvét, amikor is utasítást adunk, hogy a készülék a felvett spektrum után mennyi ideig ,ne foglalkozzon” ugyanazzal az ionnal. Az Orbitrap Elite készülékben a tömegmérés a nagy felbontású Orbitrapban történik, és közben már zajlik az előző tömegmérés alpján beindított ioncsapda CID kísérlet.

A proteomika a sejtek fehérjetartalmának minőségi és mennyiségi analízise. Ha előzetes információk nélkül, „előítélektől mentesen” akarunk sokféle fehérjét azonosítani, akkor az összehasonlítás alapja csak valami biztosan megjósolható és egyértelműen meghatározható tulajdonság lehet, és ez a tömeg. MS/MS adatokból lehet de novo szekvenálni, de ez többnyire lassú és nehézkes [Medzihradszky \& Chalkley 2015]. De szerencsére van egy „megkerülö” eljárás: egy ismert szekvenciájú fehérje adott specificitású enzimmel (esetünkben tripszinnel) emésztve jellemző és kiszámítható tömegü hasítási termékeket produkál. A valós emésztményt összevethetjük egy fehérje-adatbázis tripszines emésztésének „in silico” eredményeivel, és ilyen 
módon azonosíthatjuk az analizált fehérjét. A tömegspektrometriás fehérjeazonosítás tehát adatbázis-függő. A genom szekvenálásnak hála hatalmas fehérje-szekvencia adatbázisok állnak rendelkezésünkre. Több faj teljes genomját megszekvenálták már, és a hozzáférhető információ napról napra nő. Persze az adatbázis méretével annak az esélye is növekszik, hogy több fehérje produkál hasonló tömegü hasítási termékeket. Különösen, ha belegondolunk, hogy biológiailag és kémiailag aktív vegyületeket analizálunk, azaz a fehérjék a transzláció után enzimatikus hasításon vagy kovalens módosításon eshetnek át, és a minta-előkészítés során is előfordulhatnak mellékreakciók. Tehát a tömegmérés önmagában nem elegendö, MS/MS analízissel a peptidek szekvenciájáról is információt kell szereznünk. Ezt a problémát oldják meg az automatizált LCMS/MS analízisek.

Miután egy emésztési elegyet LC-MS/MS-sel analizáltunk, az adatokból csúcslistát készítünk. A csúcslista-generáló programokkal az eredeti raw file-okból az adatbázis kereső programok által használható text file-okat készítünk, amelyben minden egyes prekurzor ionhoz egy fragmens sorozatot rendelünk. A lekereső program egyenként kezeli a spektrumokat. A megfelelő adatbázis összes fehérjéjét megemészti feltételeink szerint, és a mérési pontosságnak megfelelően kiválasztja valamennyi szekvenciát, ami egy adott prekurzor tömeghez passzol. Ezeket a szekvenciákat „in-silico” fragmentálja és a valós fragmensek listáját összeveti az elméleti sorozattal. A találatokat pontozza és egy valószínűség-számításon alapuló értékkel azt is számszerüsíti, hogy mekkora a valószínűsége, hogy a kapott spektrumegyezés a véletlen müve (E-value). Az egymástól függetlenül, egyenként azonosított peptideket végül fehérjékbe sorolja a lekereső program. Az adatbázisok méretének növekedésével, kovalens módosítások és nemspecifikus hasítások engedélyezésével a random azonosítások esélye nő. A megbízhatóság növelése érdekében azt vezették be, hogy az adatbázisokat „megtoldjuk” valamennyi valós szekvencia randomizált változatával, ún. „hamis” (decoy) fehérjékkel. Az eredmények kiértékelésénél a hamis fehérjéket azonosító találatok száma jelzi, hogy hány kérdéses azonosítás lehet a valós peptideket azonosító találatok között is. 
Fehérjék kvantitatív analízise

Az alkalmazott proteomikában általában két vagy több minta számszerü összehasonlítására van szükség (diagnosztikában, egészséges és beteg minták, éles és kontroll minták összevetésekor). Egyes peptidek abszolút mennyisége és az őket képviselő peptidek intenzitása között azonban nincs megjósolható összefüggés. Az adott jel intenzitását többek között a peptid szekvenciája, bázicitása, és a minta komplexitása egyaránt befolyásolják.

Léteznek stabil izotópos jelölő módszerek, melyekkel hasonlóan, de jól megkülönböztethetően jelölünk fehérjéket, összekeverjük őket, enzimes emésztés után pedig detektálhatjuk, hogy a különböző jelölést tartalmazó fehérjék milyen mennyiségben voltak jelen a mintákban. Elvárás, hogy a jelölt és jelöletlen peptidek között legalább 4-8 Da különbség legyen, hogy a könnyü és nehéz variáns szétváljon. ICAT (Isotop Coded Affinity Tag) módszerrel a fehérjék ciszteinoldalláncát alkilezzük könnyü $\left(\mathrm{H}_{8}\right.$ vagy nehéz $\left(\mathrm{D}_{8}\right)$ alkil csoporttal, majd a relatív intenzitás adatokból (MS jelintenzitásból) végzünk kvantitatív analízist. A módszer hátránya, hogy relatíve kevés peptidet jelöl fehérjénként, és ráadásul ezek nem is eluálódnak egyszerre a beépült nehéz hidrogén miatt. Mivel a deutérium-beépüléssel a peptidek retenciós ideje megváltozik, ezért inkább ${ }^{13} \mathrm{C}$-at vagy ${ }^{15} \mathrm{~N}$-öt használnak jelölőként. Stabil izotóppal történő jelölést alkalmazhatunk úgy, hogy nehéz aminosavakat viszünk be a sejtkultúrába (SILAC, Stable Isotope Labeling) [Ong 2002]. Ezzel a módszerrel ${ }^{13} \mathrm{C},{ }^{15} \mathrm{~N}$ vagy ${ }^{18} \mathrm{O}$ izotópokkal módosított aminosavakat építünk be a fehérjékbe, pl. arginint és lizint, tehát minden triptikus peptidből lesz könnyű és nehéz variáns, miután összekevertük, és megemésztettük a vizsgálandó fehérjemintákat. Tömegspektrometriás analízis után a kvantitálást a peptidek relatív intenzitásából végezzük. Pl. ${ }^{13} \mathrm{C}$ használatával argininenként 6 Da tömegkülönbség detektálható. Ahhoz, hogy a nehéz aminosavak beépülése minél tökéletesebb legyen, a sejteket megfelelően hosszú ideig kell az izotóppal „etetni”. Tehát ez az út leginkább csak akkor járható, ha sejt-tenyészettel dolgozunk. Születtek tanulmányok SILAC-jelölt állatokról és növényekröl is [Doherty 2005, Lewandowska 2013], de a költségek csillagászatiak. MS/MS alapon is végezhetünk kvantitatív összehasonlítást. Több, 4-8 különböző állapot is összehasonlítható iTRAQ (Isobaric tags for relative and absolute quantitation) jelöléssel, amikor a már megemésztett peptidkeverék aminocsoportjait módosítjuk azonos kémiai szerkezetü, de különböző izotóp-összetételü csoportokkal, melyeknek additív tömege megegyezik, a töltést viselő fragmensek tömege azonban eltér [Ross 2004]. 
Míg a SILAC jelölésnél a minta-előkészítés elött keverjük össze az összehasonlítandó mintákat, addig a kémiai jelöléseket a már megemésztett mintákon külön-külön ejtjük meg, és csak utána vegyítjük a jelölt keverékeket.

Jelölés nélkül is végezhetünk azért kvantitatív összehasonlításokat. A spektrumszámlálás módszerének alapja az, hogy egy adott fehérjére eső azonosított spektrumok száma egy adott mintában bizonyos korlátok mellett tükrözi a fehérje mennyiségét a vizsgált elegyben [Old 2005]. Pontosabb az összehasonlítás, ha a várható fehérjék számát is figyelembe vesszük. Relatív kvantitatív összehasonlításoknál megfelelő szoftverekkel a fehérjét képviselő peptidek intenzitását is össze lehetne hasonlítani, de ezek hiányában mi a spektrum-számlálás mellett döntöttünk.

A kvantitatív proteomika egy speciális problémája néhány komponens jelenlétének vagy hiányának igazolása azonosan előkészített emésztési elegyekben. Tegyük fel, hogy MS/MS adatokból megbízhatóan azonosítunk egy komponenst egy mintában. Jól reprodukálható kromatográfiával a pontosan mért tömeg és retenciós idő elegendő lehet ahhoz, hogy parallel preparátumokban CID adatok nélkül is igazoltnak lássuk a kérdéses peptid jelenlétét [Andreev 2012]. Természetesen ilyen összehasonlítások esetén off-line frakcionálás nem előzheti meg az LC-MS analízist, mert kis eltérések a frakciószedés során megváltoztathatják a frakciók összetételét. 


\section{Célkitüzés}

Munkánk alapja az volt, hogy a pillangós virágú növények NCR peptideket termelnek, mely vegyületek irányítják és kontrollálják a szimbiotikus baktériumok differenciálódását. Számos kísérlet bizonyította viszont, hogy a kimutatható transzkripciós aktivitás nem mutat egyértelmü korrelációt a fehérjeszinten megjelenő “termékkel”, sem kvalitatíve, sem kvantitatíve [Griffin, 2002, Pratt 2002]. Először is kérdés, hogy mindezen géntermékek egyáltalán megjelennek-e a bakteroidokban, s ha megjelennek, mikor teszik azt; mennyi az NCR-fehérjék féléletideje, s egymásra milyen hatást gyakorolhatnak stb. Feladatunk tehát a nitrogénkötésben részt vevő bakteroidok proteomikai vizsgálata, elsősorban az NCR peptidek fehérjeszintü azonosítása volt. Kísérleteink jelentős részét Sinorhizobium medicae (WSM419) és S. meliloti (Sm1021) baktériumokkal fertőzött Medicago truncatula A17 Jemalong növény gümőivel végeztük. A vad típusú $M$. truncatula gyökérgümöinek vizsgálata mellett $M$. truncatula $6 \mathrm{~V}$ mutáns gümöinek növényi és bakteriális eredetü fehérjéit is analizáltuk.

Céljaink:

1) Vizsgálódásunk elsődleges célja az volt, hogy a baktériumok transzformálására és irányítására szolgáló növényi-eredetü NCR peptidek jelenlétét kimutassuk a bakteroidokban. Célunk volt továbbá a detektált szekvenciák alapján a szignál-peptidáz hasítóhelyének igazolása.

2) Arról is igyekeztünk információt szerezni, hogy mi lehet a biológiai szerepe ezeknek a polipeptideknek. Ehhez ki akartuk deríteni, hogy:

a) van-e különbség a különböző fejlődési stádiumban levő bakteroidok NCR-tartalmában,

b) mi a különbség a vad típusú és egy adott fenotípussal rendelkező mutáns növény gümőinek NCR és bakteriális fehérje tartalmában,

c) mely bakteriális és növény fehérjék hatnak kölcsön egy bizonyítottan antimikrobiális hatású NCR peptiddel.

Természetesen a fenti célok eléréséhez ki kellett dolgoznunk a megfelelő minta előkészítő eljárásokat. A gümő szöveti szerkezetéből adódóan meg kellett találni a megfelelő módszert a növényi és a bakteriális eredetű sejtek elkülönítésére, majd a bakteroidok anyagának feltárására. 
A minta-előkészítés lépéseit először egy bakteroid-elegyen fejlesztettük ki. Mivel a későbbiekben a vad-típusú növények mellett bizonyos mutánsok gyökérgümőiben is kutakodni szándékoztunk, és össze is kívántuk hasonlítani a kapott eredményeket, ezért az analízis teljes folyamatát ehhez a célhoz igazítottuk.

Munkámat részben Kondorosi Éva irányításával végeztem. A Kondorosi-csoport egy ideje foglalkozik az NCR247 peptid biológiai hatásával, így ennek a molekulának a lehetséges kölcsönható partnereit kutattuk.

Az NCR peptidek fehérjeszintü azonosítása alapjául szolgálhat jövőbeni alkalmazott biológiai kutatásoknak is. A Kondorosi-csoport távlati céljai között szerepel az, hogy az NCR-ek antimikróbiális hatását további teszteknek vessék alá. Az orvostudomány egyik legnagyobb problémája jelenleg az antibiotikum-rezisztencia kérdése, és az NCR peptidek mint természetes antibiotikumok jó alternatívái lehetnek a ma használt szereknek, bevethetőek lehetnek a jövőben, akár a humán- és állatgyógyászatban akár a növényvédelemben. 
3. Anyag és módszer

3.1. Növényi anyagok és baktériumok

Vizsgálatainkat a vad típusú Medicago truncatula Jemalong A17 és M. truncatula 6V mutáns növények különböző Sinorhizobium baktériumtörzsekkel fertőzött gyökérgümőiből izolált fehérjékkel végeztük.

A 6V mutáns (11. ábra) M. truncatula növényt kooperációs partnereink hozták létre a gödöllöi Növénygenomikai és Növény-mikroba Interakció Csoportban (Szent István Egyetem). Ez a mutáns növény gümöképzésre képes ugyan, nitrogénkötésre azonban már képtelen.
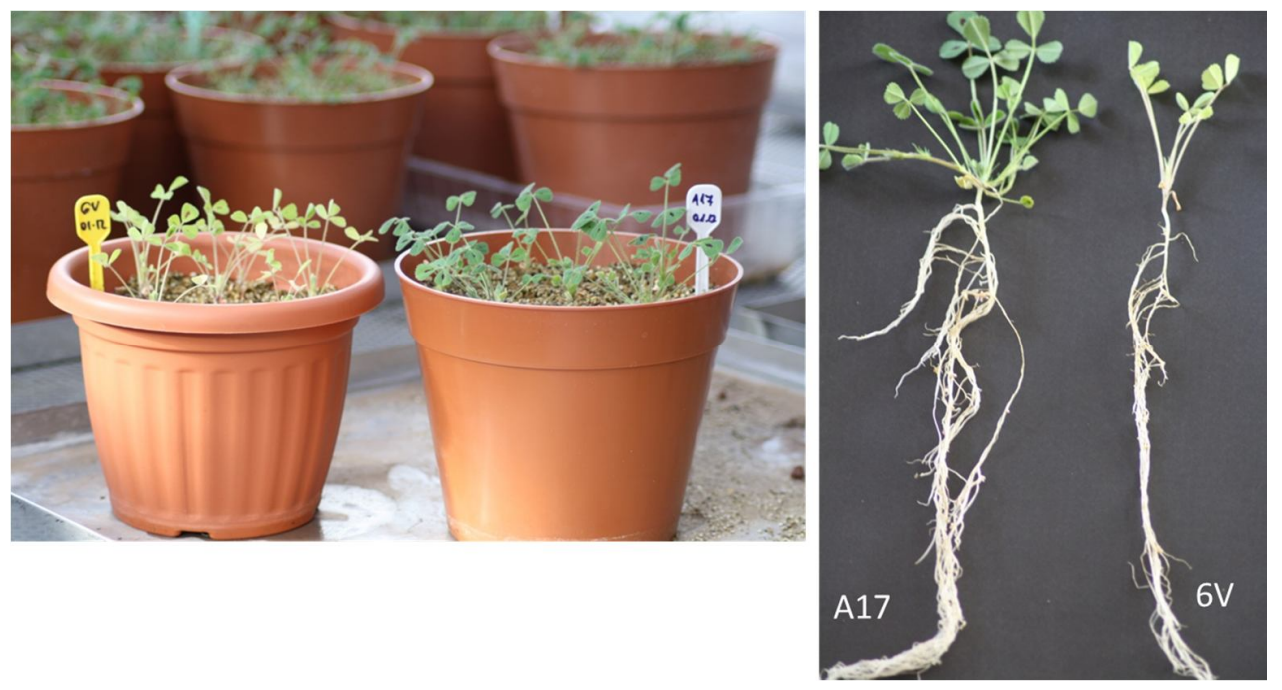

11. ábra: M. truncatula A17 és $6 \mathrm{~V}$ növénykék eltérő fejlettsége a bakteriális fertőzést követő 30 . napon

Növények növesztése és baktériummal fertőzése a Medicago truncatula Handbook alapján történt (www.noble.org/MedicagoHandbook, E-P Journet 2006: Rhizobial inoculation and nodulation of M. truncatula, Garcia 2006).

A növényeket Sinorhizobium meliloti (Sm1021) illetve S. medicae (WSM419) baktériumtörzzsel fertőztük a növesztés során. NCR247-peptiddel kölcsönható partnerek kutatásában használt baktériumkultúrákat 7.0 pH-jú (OD600 = 0.1) $20 \mathrm{mM}$ kálium-foszfát pufferben inkubálták a peptiddel (0.1-töl $500 \mu \mathrm{M}$-ig) 2 órán keresztül [Farkas A, 2014]. 
3.2 Bakteriális fertőzés, gümőszedés

A fertőtlenített magvakból kifejlödött növénykéket csíráztatás után olyan folyadékkultúrában (factory) neveltük, ahol a növekedésükhöz szükséges tápanyagokat, a nitrogén kivételével, vízben oldott formában kapták. Az első 4-5 napon (még az oldalgyökerek kifejlődése előtt) már célzottan nitrogénmentes tápoldatban nevelték a növényeket, így a gümők az elsődleges gyökereken fejlödnek ki. 3 hét elteltével S. medicae WSM419 vagy S. meliloti (Sm1021) baktériummal megfertőztük a növényeket, majd 2-3 héttel a fertőzést követően szedtük le a nitrogénhiány és a fertőzés együttes hatására kialakult gyökérgümőket. A leszedett gümők azonnal jéghideg extrakciós pufferbe kerültek (125 mM KCl, $50 \mathrm{mM}$ nátrium-szukcinát, $10 \mathrm{mM}$ K-foszfát, $\mathrm{pH}=7$ ). A gümők homogenizálása mozsárban, mozsártörővel történt egy kevés kvarchomok (Sigma) hozzáadásával.

\subsection{Fehérjetisztítási eljárások}

Az NCR peptidek azonosítására szolgáló kísérleteinkben háromféle fehérje-preparálási eljárással dolgoztunk (12. ábra). Az általánosan elfogadott bakteroid-elválasztási módszer a Percollgrádiensen való ultracentrifugálás volt [McRae, 1989], mellyen a teljesen differenciálódott bakteroidok jól elkülöníthető frakciót alkotnak. A Percoll oldat a GE Healthcare által levédett kolloidális szuszpenzió, mely polivinil-pirrolidonnal bevont, $17 \mathrm{~nm}$ átmérőjü silica-gyöngyökből áll [Dunkley 2008], eredetileg sejtek és sejtalkotók elválasztására kidolgozott módszer volt.

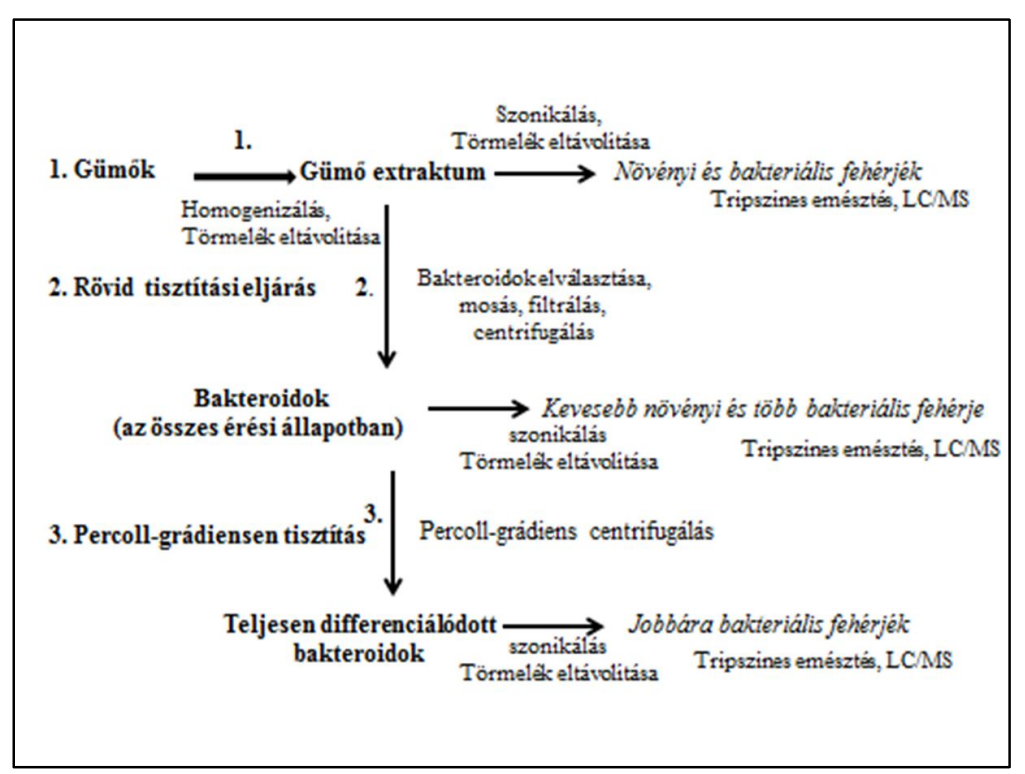


12. ábra: Az általunk használt fehérjetisztítási eljárások folyamatábrája

\subsubsection{Intakt gümö}

$\mathrm{Az}$ intakt, azaz tisztítatlan gümő analíziséhez biológiai ismétlésenként 100 mg gümőt szüreteltünk le, ezekhez kvarchomokot adva manuálisan homogenizáltuk a mintát, majd $30 \mu \mathrm{m}$ pórusú szürőn átszürtük azt. A filtrátumokat $300 \mu \mathrm{L}$ extraháló pufferben vettük fel, melyet kettéosztottunk, a $150 \mu \mathrm{L}$-t $500 \mu \mathrm{L}$-re egészítettük ki puffer oldattal a feltárás előtt. Ugyanezen eljárásokon estek át elöször a röviden és a Percoll-grádiensen tisztított minták is.

\subsection{2 "Rövid" tisztítási eljárás}

Az intakt gümö-extraktumot $10 \mu$ m-es szürőn átszürtük (azért, hogy a növényi sejtmagok nagy részétől megtisztítsuk a mintát), majd a minta bakteroid tartalmát centrifugálással koncentráltuk (3800 x g, 5 perc). A növényi fehérjék nagy részének eltávolítása céljából háromszor mostuk a mintát $10 \mathrm{mM}$ Tris- $\mathrm{HCl}$ pufferben $(\mathrm{pH}=7.2)$. A csőben maradt csapadék-frakció egy része extraháló pufferben feloldva került ultrahangos feltárásra, a másik része ezt követően Percollgrádiensen történő tisztítási folyamaton esett át a feltárás elött.

\subsubsection{Percoll-grádiens centrifugálás}

A teljesen differenciálódott bakteroidokat ebböl a bakteroid-keverékből izoláltuk $70 \%$ (v/v) Percoll-grádiens centrifugálással (48000 x g, 45 perc). A nitrogén-fixáló bakteroidokat tartalmazó réteg egy különálló felső fázisként jelenik meg a centrifugálás után. Ezt a fázist összegyüjtöttük, majd tízszeres térfogatra hígítottuk extrakciós pufferrel, ezután $5000 \mathrm{x}$ g fordulaton 20 percig centrifugáltuk a bakteroidokat. A különváló bakteroid frakciót egy utolsó mosást követően 500 $\mu \mathrm{L} 10$ mM-os Tris-HCl pufferben ( $\mathrm{pH}=7.2)$ vettük fel, majd a megfelelő mennyiségü mintában lévő sejteket ultrahangos szonikálással feltártuk.

\subsection{Bakteroidok feltárása ultrahangos szonikálással}

Az ultrahangos bakteroid-feltárást a Szegedi Tudományegyetem Biotechnológiai Tanszékén [Bandelin Sonopuls ultrahangos homogenizátor (Berlin, Germany) HD3100] valamint a Szegedi Biológiai Kutatóközpont Biokémia Intézetében végeztük [Branson Sonifier (Fiscer Scientific]. 
Az $500 \mu \mathrm{L}$ mennyiségü, jégben tartott mintát ciklikusan ultrahangoztuk, hogy a sejtek túlzott felmelegedését elkerüljük. A Bandelin készülék használata esetén 15 másodperces ultrahangozást 20 másodperces szünet követett, összesen 15 cikluson keresztül (nettó 3.75 percig), míg a Branson készülékkel más paraméterekkel, de szintén közel nettó 4 percig ultrahangoztuk a bakteroidokat. A megfelelő feltárást követően a minta opálossá vált. A feltárt mintában lévő maradék növényi anyagok és oldhatatlan komponensek eltávolítását centrifugálással végeztük (16000 x g, 10 perc). A feltárt mintákból minden esetben fehérjemérést végeztünk, a fehérjetartalmat három egymást követő mérés átlagából határoztuk meg (NanoDrop1000, $280 \mathrm{~nm}$ hullámhossz).

3.5 A mintában lévő fehérjék C18 töltetü oszlopon való, hidrofóbicitás szerinti elválasztása A mintában található NCR-peptidek dúsítására a C18-as fordított fázisú tölteten való, hidrofóbicitás szerinti elválasztással dolgoztunk. A fordított fázisú frakcionálás (C18 oszlopon) során az általunk keresett peptidek relatíve hidrofób természetét használtuk ki. Bizonyos mértékig méret szerint is frakcionáltunk fordított fázison, mert a nagyobb fehérjék jelentős része fennragadt a C18-as oszlopon. A C18 szeparáláshoz is az előzetes fehérjemérés alapján számított $50 \mu \mathrm{g}$ fehérjéből indultunk ki. A kiindulási mintát $150 \mu \mathrm{L}$-re hígítottuk HPLC-vízzel és 10\% TFA-tartalmú vízzel olyan arányban, hogy a TFA végkoncentrációja 1\% legyen. A C18-töltetü hegyeket először $0.1 \%$ TFA/50\% ACN-oldattal nedvesítettük (5-ször $200 \mu \mathrm{L}$ ), majd az ekvilibrálás után $(0.1 \%$ TFA/ H2O, 5-ször $200 \mu \mathrm{L})$ felkötöttük a mintát a C18-töltetü hegyre. $0.1 \%$ TFA-val megsavanyított 72\% -os ACN-tartalmú oldattal eluáltuk a komponenseket [Gruber et al 2008].

\subsection{Oldatban emésztés}

Az NCR-peptidek azonosítására szolgáló kísérleteinkben a mintákat oldatban, esetenként 1DSDS-PAGE gél formájában kaptuk meg. Oldatban emésztés esetén az oldatokból előzetes fehérjemérés alapján $50 \mu \mathrm{g}$ fehérjetartalomnak megfelelő mennyiségekkel dolgoztunk, első lépésként teljesen beszárítottuk a mintákat. A száraz minta fehérjetartalmát $20 \mu \mathrm{L} 6 \mathrm{M}$ guanidin 
hidroklorid-oldatban felvéve és $80{ }^{\circ} \mathrm{C}$-on 5 percig inkubálva denaturáltuk, ezt követően $100 \mathrm{mM}$ TCEP oldat hozzáadásával (végkoncentráció $5 \mathrm{mM}, 56{ }^{\circ} \mathrm{C}, 30$ perc) redukáltuk, majd $100 \mathrm{mM}$ IAM hozzáadásával alkileztük (szobahömérséklet, sötét, 30 perc). A mintát ezek után $50 \mathrm{mM}$ ABC-pufferrel $(\mathrm{pH}=8.5$ ) hígítottuk (kaotróp koncentráció $\sim 0.75 \mathrm{M}$ ), majd $1 \%$ tripszin hozzáadásával $37{ }^{\circ} \mathrm{C}$-on 4 órán keresztül inkubáltuk. Az emésztés leállítása TFA hozzáadásával történt (végső $\mathrm{pH}=3$ ). A mintákat $\mathrm{C} 18$-töltü oszlopon (OMIX C18) tisztítottuk, majd az eluátumot tökéletesen beszárítottuk. Beszárítás után a mintát $15 \mu \mathrm{L} 0.1 \% \mathrm{FA} / \mathrm{H}_{2} \mathrm{O}$ (HPLC 'A' oldószer) oldatban vettük fel és higítást követően LC-MS/MS-analízisnek vetettük alá.

\subsection{Coomassie Brilliant Blue 1D SDS-PAGE gél minták emésztése protokoll}

A mintától függően a kivágott gélsávokat vagy megfelelő darabokra vágva a teljes gél-csíkot emésztettük. A teljes csík emésztésekor azt a benne lévő diszkrét sávoktól függetlenül vagy célzottan a gélben látszó sávokra koncentrálva daraboltuk, majd a normál gélben emésztés protokoll szerint tripszinnel emésztettük. A tripszines emésztés első lépéseként a gélcsíkokat kis darabkákra vágtuk, majd háromszor mostuk öket $25 \mathrm{mM} \quad \mathrm{ABC} / 50 \%$ ACN oldattal. Redukálálásként $10 \mathrm{mM}$-os DTT oldatban $56{ }^{\circ} \mathrm{C}$-on fél órát inkubáltuk a mintákat, majd ezt követően 55 mM-os IAM-oldattal alkileztük a kitekert fehérjéket, így blokkolva a szabad SHcsoportokat (RT, 30 perc, sötétben). Újabb mosási lépéseket (25 mM ABC/50\% ACN) követően a géleket beszárítjuk, majd a fehérjemennyiséghez megfelelő koncentrációban tripszin-oldatot (25 mM ABC-pufferen) tettünk a gélekre. Rövid rehidratálást követően a tripszin-oldat feleslegét eltávolítottuk, a gélekre $25 \mathrm{mM}$ ABC-puffert pipettáztunk és $37{ }^{\circ} \mathrm{C}$-on 4 órán keresztül inkubáltuk. Ezt követően a megemésztett fehérjéket már peptidekként extraháltuk ki a gélekből. Ehhez $50 \mu \mathrm{L} 50 \% \mathrm{ACN} / 1 \% \mathrm{FA}$ oldattal 20 percig rázattuk a géleket, majd rövid ultrahangos szonikálást követően ezt az oldatot leszívtuk a gélek tetejéről és egy metanollal átöblített csőben (Eppendorf) gyüjtöttük. Háromszor végeztük el az extrahálást, az összegyüjtött extraktumot vákuum-centrifugában tökéletesen beszárítottuk, beszárított mintákat a festés erőssége alapján feltételezett fehérjemennyiség szerinti térfogatú 0.1\% FA/ ULC-MS $\mathrm{H}_{2} \mathrm{O}$-ben vettük fel, majd analizáltuk. 
Az NCR247-peptiddel kölcsönható bakteriális fehérjék azonosításakor egyes kísérletekben a gélben elválasztott fehérjék festéséhez ezüst-nitrátot használtak (az ezüst-festés a legérzékenyebb módszer a fehérjék gélen belüli festésére, mellyel akár 0.5 ng fehérjét tartalmazó sávok is kimutathatók), ilyenkor az emésztési protokoll első lépéseként a gélekből Destainer-kit (Invitrogen) hozzáadásával el kell távolítani azt az ezüstöt, amely a fehérjével reagált, és gátolná a fehérje kinyerését a gélből [Shevchenko 2007].

3.8 C-terminálisán jelölt NCR247 peptiddel végzett StrepII- vagy FLAG-tag affinitáskromatográfia

A peptid lehetséges intracelluláris fehérjepartnereinek, azaz sejten belüli célfehérjéinek azonosítása érdekében az NCR247 szekvenciáját a szintézis folyamán megjelöltük egy 8 aminosav hosszú StrepII-(WSHPQFEK-szekvencia) vagy FLAG-(DYKDDDDK-szekvencia) taggel a C-terminális végen, melyek segítségével Strep-Tactin vagy FLAG-affinitás oszlopon az NCR a lehetséges interakciós partnerével együtt könnyebben „kifogható”. A szintézisek >95\% tisztasággal, az elfogadott „,solid phase peptide synthesis” szerint történtek [ProteoGenix].

A kálium-foszfát pufferben lévő $S$. meliloti baktérium mintát (OD600=2) vagy gümőkből izolált bakteroidokat NCR247-StrepII vagy NCR247-FLAG-gel kezeltük ( $3 \mu \mathrm{M}$ végkoncentrációban, 2 órán keresztül), majd a $0.5 \mathrm{~mL}$ tisztított sejt-extraktumot $200 \mu \mathrm{L}$ Strep-Tactin vagy FLAGaffinitás oszlopon (M2 agaróz) tisztítottuk $\left(1\right.$ óra, $\left.20^{\circ} \mathrm{C}\right)$. Az oszlopokat ezután nyolcszor mostuk, majd a hozzákötödött fehérjéket $2.5 \mathrm{mM}$ destionbiotinnal vagy $200 \mu \mathrm{M}$ FLAG peptiddel eluáltuk. Az átfolyó, a mosó és eluátum frakciókat 10\%-os (w/v) vagy 4-12\%-os (w/v) grádiens SDS poliakrilamid-gélen választottuk el, majd a kapott fehérjesávokat ezüst festéssel tettük láthatóvá. 
3.9 Fehérjeazonosítás (készülékek, azonosításkor használt paraméterek) kísérletek szerint

\subsubsection{NCR-peptidek azonosítása M. truncatula vad típusú (A17) gümökből}

\subsubsection{LC-MS/MS analízis}

Az emésztési elegyek frakcionálását egy nanoAQUITY UPLC rendszerrel (Waters) végeztük, és egy LTQ-Orbitrap Elite tömegspektrométer szolgált detektorként (Thermo Scientific). A sótalanítás után beszárított és $15 \mu \mathrm{L}$ 0.1\% FA/ULC-MS $\mathrm{H}_{2} \mathrm{O}$-oldatban felvett mintákból $5 \mu \mathrm{L}-\mathrm{t}$ négyszeres mennyiségre hígítottunk, melyből $5 \mu \mathrm{L}$-t injektáltunk egy LC-MS analízisre.

A mintákat trap-oszlopra injektáltuk (Symmetry, C18, $5 \mu \mathrm{m}$ (szemcseméret), $180 \mu \mathrm{m}$ (belső átmérö) x $20 \mathrm{~mm}$ (oszlop hossza)) $10 \mu \mathrm{L}$ /perc áramlási sebességet használva ( 3 perc, $0.1 \%$ FA/ $\left.\mathrm{H}_{2} \mathrm{O}\right)$, majd egy AQUITY UPLC BEH C18 oszlopon $(1.7 \mu \mathrm{m}, 75 \mu \mathrm{m}$ x $200 \mathrm{~mm}) 400 \mathrm{~nL} /$ perc áramlási sebességgel elválasztottuk (100 perces lineáris grádiens, 0-40\% $0.1 \% \mathrm{FA} /$ acetonitril). Az Orbitrapben mért tömegspektrumból a 10 legintenzívebb, többszörösen töltött iont választottuk ki ioncsapdás fragmentációra, a fragmenseket az ioncsapdában mértük (35\% normalizált ütközési energiával, 10 milliszekundum aktivációs idő, AGC értékek: $10^{6}$ Orbitrapre és $10^{4}$ ioncsapdára vonatkoztatva); 30 másodperces dinamikus kizárás beállításával igyekeztünk a minta minél több komponenséröl MS/MS-spektrumot felvenni. A kromatográfiás időt 120 percben határoztuk meg, az 5000-nél kisebb intenzitású ionokkal nem foglalkoztunk.

Minden emésztményt egyszer analizáltunk, ez alól az intakt gümő-minták voltak kivételek, melyekből egymást követő három technikai ismétlés történt.

\subsubsection{Adatbázis lekeresés}

Miután a kapott peptidkeverékeket LC-MS/MS-sel analizáltuk, a nyers adatokból PAVA_ 30sep2010 vagy Proteome Discoverer 1.4 programmal készítettünk csúcslistákat. A csúcslistageneráló programokkal az eredeti raw file-okból az adatbázis kereső programok által használható text file-okat készítünk. Az adatbázis-lekereséshez Mascot programot és ProteinProspector (v.5.10.10) programot használtuk, két fehérje-adatbázisban keresve párhuzamosan: Uniprot adatbázisban (UniProtKB.2013.6.17), illetve a saját adatbázisunkban, mely az alábbi fehérjéket tartalmazta: M. truncatula szimbiotikus génekről fordított fehérje-szekvenciák (934 fehérje bejegyzés a következőkböl kombinálva: UniProt adatbázis, $M$. truncatula 3.5 és 4.0v1 genome 
assembly, M. truncatula Gene Index Release 11.). Az azonosítások megbízhatóságának további növelése érdekében minden valós szekvencia mellett annak randomizált változata is megtalálható volt az adatbázisban. A keresés feltételeit fajokra is korlátoztuk, M. truncatula, S. meliloti és $S$. medicae fehérjékre (110572/36042779 fehérje). A prekurzor-ion mérési pontosságát 10 ppm-en belül, a fragmens ionok tömegpontosságát 0.6 Da határon belül tekintettük elfogadhatónak. Féltriptikus hasítást és legfeljebb két kihagyott hasítóhelyet engedélyeztünk a lekeresés folyamán azért, mert a keresett kis méretü NCR-ek szekvenciája sok esetben nem tartalmaz vagy nem megfelelő mennyiségben tartalmaz lizin és arginin aminosavakat ahhoz, hogy jól detektálható triptikus peptideket kapjunk az emésztés eredményeként. A fehérjék fix módosításaként a ciszteinek karbamidometilezését (Carbamidomethyl (C), lehetséges módosításokként a fehérjék $\mathrm{N}$-terminálisának acetilálódását (Acetyl $(\mathrm{N}$-term)), a metionin oxidációját (Oxidation $(\mathrm{M})$ ) és a triptikus peptidek N-terminális végén lévő glutamin gyürüvé záródását (Gln->pyro-Glu (N-term Q)) vettük figyelembe. Az FDR minden mintánál 1\% alatt volt.

Elfogadási kritériumok a következök voltak (Protein Prospector): minimum peptid score: 15, minimum protein score: 20; maximum peptid E-value: 0.1, maximum protein E-value: 0.01.

\subsubsection{Peptidszintü összehasonlítás, fitXIC program, referencia-lista}

Annak érdekében, hogy a különböző preparációs eljárásokkal kapott fehérjetalálatokat peptidszinten össze tudjuk hasonlítani egy referencia-listát készítettünk az adatfile-ok összegzett eredményeiből úgy, hogy minden NCR-peptid esetén csak a legjobb CID adatokat listáztuk a prekurzor ionok m/z értékével és a retenciós időkkel együtt. Ez a jel-intenzitások, azaz a csúcs alatti területek alapján kvantitál. A centroidált MS-adatokat PAVA program segítségével nyertük a nyers (raw) adatokból, fitXIC program segítségével összevetettük ezeket az elkészített referencia listával [Guan 2011]. A program az alábbi adatok alapján végzi az összevetést: a megtalált peptid retenciós ideje (RT), a csúcs alatti terület nagysága (Area), a prekurzor ion intenzitása (csúcs magassága, intenzitás), a csúcs szélessége (delta(t)) és egy mérőszám az azonosítás megbízhatóságáról, mely 0 és 1 közé eshet, de 0.6 alatt 0 -t ad, azaz azt nem megbízható azonosításnak tekintettük. A prekurzor tömegek eltéréseit 10 ppm pontossággal fogadtuk el, míg a maximális retenciós idő differenciát 2 percben szabtuk meg. 
3.9.2. Medicago truncatula A17 vad és $6 \mathrm{~V}$ mutáns proteóm összehasonlítása

A kísérlet során $M$. truncatula A17 vad-típusú és 6V mutáns növényeket fertőztünk meg $S$. medicae (WSM419) endoszimbionta baktériummal, majd a fertőzéstől számított 15. napon „leszüreteltük” a gyökéren kifejlődött gümőket. A vizsgálatokat 3 párhuzamos biológiai mintán végeztük, melyek különböző időpontokban, de tökéletesen megegyező paraméterek között növesztett és fertőzött növényeken fejlődő gümő-mintákat jelentenek. A gümök fehérjetartalmát a „rövid” tisztítási eljárással nyertük ki, majd a korábban bemutatott módon feltártuk a mintáinkat. Minden biológiai mintából három technikai ismétlés is készült, tehát mind a vad, mind a mutáns növény gyökérgümőiből feltárt fehérje-komplex 9-szer lett analizálva oldatban emésztést követően, emellett a második biológiai ismétlésböl CBB-festett SDS-PAGE gél futtatása is történt, melynek eredményeit az oldatban emésztés eredményeivel együtt tárgyaljuk. A különböző tisztítási eljárásokat ultrahangos szonikálással történő feltárás követte, majd oldatban vagy gélfuttatást követően gélben emésztési eljárással a minta fehérjetartalmát triptikus peptidekre bontottuk.

\subsubsection{LC-MS-MS analízis}

A feltárás utáni fehérjetartalom-mérés segítségével $50 \mu \mathrm{g}$ fehérjemennyiségből indultunk ki az oldatban emésztéskor, míg a gél minta esetén a teljes gélcsíkot 12 darabra vágtuk, ezeket egyenként emésztettük (a 3.7 fejezetben leírtak szerint), a csúcslistákat ezután egyesítettük és egy adatsorként kezelve elemeztük. A mintákból minden esetben három egymást követő mérés történt a 3.9.1.1. fejezetben ismertetett paraméterekkel. Az adatbázis-lekeresést a 3.9.1.2 fejezetben leírt paraméterek szerint végeztük azzal az eltéréssel, hogy a prekurzor-ion mérési pontosságát 5 ppmre szükítettük.

\subsubsection{Relatív kvantitatív analízis spektrumszámlálással}

Vad típusú és a $6 \mathrm{~V}$ mutáns növény gümőiböl izolált fehérjéket összehasonlító táblázatok formájában mutatjuk be. A fehérjetalálatok eredményeit a spektrumszámlálás módszerével szükítettük: azon fehérjék, melyek mindkét gümőtípusban megtalálhatóak voltak, és normálás, valamint a spektrumszámlálás módszerének (adott fehérjére eső azonosított spektrumok száma (peptide count) és a mintából azonosított össz-spektrumszám (szumma peptide count) hányadosok minták közötti összehasonlítása) alkalmazása után a vad -típusú mintában legalább 
50\%-kal akkora mennyiségünek mutatkoztak, mint a mutáns genotípusú gümökben, azok mennyiségét az adott gümőtípusra szignifikánsan jelentősebbnek értékeltük. Ugyanezen gondolatmenet alapján szignifikánsan jelentősebbnek értékeltük a mutáns gümőben azokat a fehérjéket, amelyek ebben a mintában mutatkoztak kétszer akkora mennyiségünek.

3.9.3 NCR247 lehetséges kölcsönható fehérjepartnereinek azonosítása tömegspektrometriával

3.9.3.1. Mintaelőkészítés, emésztés, analízis, adatbázis lekeresés

GUS-festés: célzottan az NCR247 fehérje génjének kifejeződésének nyomon követésére szolgáló szemi-kvantitatív eljárást végeztünk ( $\beta$-glukuronidáz aktivitáson alapuló hisztokémiai enzimfestés).

Az NCR247 lehetséges kölcsönható partnereinek azonosítása minden esetben a 3.8 fejezetben már ismertetett módon, C-terminálisán jelölt peptiddel történt. Az NCR247 lehetséges bakteriális kölcsönható partnereinek azonosítása 1D-SDS-PAGE gél mintákból, bakteroid-eredetü fehérjepartnerek azonosítása oldatban lévő mintákból, oldatban emésztést követően történt. A kölcsönható fehérjék azonosítását nyolc kísérleten keresztül végeztük, hét kísérletben izolált $S$. meliloti baktérium mintával, egy esetben $S$. meliloti differenciált bakteroid mintával dolgoztunk. Az első és az utolsó baktérium-minta analízise között négy év telt el, ez érzékelhető is ebben a fejezetben, amikor ismertetjük a használt készülékeket, a csúcslista-generáló és lekereső szoftvereket és a használt adatbázisokat. Szekvenciák összehasonlításához a BLAST homológiakeresést használtuk [Altschul 1990].

\subsubsection{Anyagok és módszerek ismertetése kísérletenként}

1. kísérlet: NCR247 lehetséges kölcsönható partnereinek azonosítása S. meliloti baktériumból (ezüst-festés, 1D-gél)

A gélsávokat színtelenítés után a szokásos módon (http://ms-facility.ucsf.edu/ingel.html) tripszinnel emésztettük redukálás és alkilezés után 18 órán át. A triptikus peptidelegyeket Bruker MALDI-TOF tömegspektrométerrel, DHB mátrixban megmértük, ezen kívül LC-MS/MS analízisnek vetettük alá Thermo LCQ-Fleet ioncsapda készülékkel. A Thermo ioncsapda adatokat a Mascot Distiller 2.1.1.0 szoftverrel dolgoztuk fel, majd on-line kerestük le az NCBInr 20080718 (6833826 szekvencia) adatbázisban és in-house a saját $S$. meliloti (6218 szekvencia) 
adatbázisban a Mascot/MatrixScience programcsomaggal. 0,6 Da pontosságot használtunk a prekurzorra és $1 \mathrm{Da}$ pontosságot a fragmens ionokra és 2 kihagyott triptikus hasítóhelyet engedélyeztünk.

2. kísérlet: NCR247 lehetséges kölcsönható partnereinek azonosítása S. meliloti baktériumból (ezüst-festés, 1D-gél)

A gélsávok tripszines emésztését az előző kísérletnél leírt módon, de 5 órán keresztül végeztük, majd ezután az előzőleg ismertetett paraméterekkel analizáltuk a mintát.

3. kísérlet: NCR247 lehetséges kölcsönható partnereinek azonosítása S. meliloti baktériumból (ezüst-festés, 1D-gél)

A gélsávok tripszines emésztését az előző kísérletnél leírt módon, de 4 órán keresztül végeztük, majd ezután Thermo LCQ-Fleet ioncsapda készülékkel, ugyanazokkal a paraméterekkel analizáltuk a mintát.

4. kísérlet: NCR247 lehetséges kölcsönható partnereinek azonosítása S. meliloti baktériumból (ezüst-festés, 1D-gél)

A gélsávok tripszines emésztését az előző kísérletnél leírt módon, 4 órán keresztül végeztük, majd ezután Thermo LCQ-Fleet ioncsapda készülékkel, ugyanazokkal a paraméterekkel analizáltuk a mintát. Az adatokat a Mascot Distiller 2.1.1.0 szoftverrel dolgoztuk fel, majd online kerestük le (www.matrixscience.com) a teljes NCBInr 20091202 adatbázisban (10107245 szekvencia), illetve in-house a saját adatbázisban (S. meliloti, M. truncatula fehérjéket és NCRpeptideket tartalmaz, 6218 szekvencia). 0,6 Da pontosságot használtunk a prekurzorra és $1 \mathrm{Da}$ pontosságot a fragmens ionokra, 2 kihagyott triptikus hasítóhelyet engedélyeztünk.

5. kísérlet: NCR247 lehetséges kölcsönható partnereinek azonosítása S. meliloti baktériumból (ezüst-festés, 1D-gél)

A gélsávokat színtelenítés után a szokásos módon, redukálás és alkilezés után tripszinnel emésztettük 4 órán át. A triptikus peptidelegyeket LC-MS/MS analízisnek vetettük alá Thermo LCQ-Fleet ioncsapda készülékkel. Az adatok feldolgozását és az adatbázis-lekeresést a 4. kísérletben leírtak szerint végeztük. 
6. kísérlet: NCR247 lehetséges kölcsönható partnereinek azonosítása S. meliloti baktériumból (ezüst-festés, 1D-gél)

C-terminálisán jelölt NCR247 kölcsönható partneit kerestük affinitás kromatográfiás módszerrel S. meliloti baktériumban az aspecifikus kölcsönhatók kizárásával. Erre a Strep-NCR247 két változatát használtuk:

1. „A”-változat: Strep-taggel ellátott NCR 247 kevert szekvenciákkal (a ciszteinek is keverve)

2. „B”-változat: Strep-taggel ellátott 247-es fix ciszteinnel, de a többi aminosav sorrendje összekeverve.

Előzetes eredmények alapján tudtuk, hogy a kevert aminosav-sorrend ellenére a peptid átjut a membránon, és toxicitása is megmarad.

A baktérium fehérjéit és az NCR247 strep-pelt „A”-változatát összeraktuk, majd az oszlopon áteresztettük, az NCR-,„A” lehetséges kölcsönható fehérjéi felkötöttek az oszlopra. Az átfolyó elegyet összekevertük a normál Strep-NCR247-tel, egy újabb oszlopon átfolyattuk, a normál NCR247-tel kölcsönható partnereket ismét kifogtuk. Ugyanezt a kísérletet elvégeztük a fix helyzetü ciszteineket tartalmazó NCR247-tel is. A második oszlopról eluált mintát megfuttattuk saját készítésű, illetve gyári gélen is. Mind a négy esetben 1 erős fehérjesáv volt azonosítható a gélen, ezt analizáltuk LC-MS/MS-sel.

A gélcsíkokat színtelenítés, redukálás és alkilezés után tripszinnel emésztettünk 4 órán át. Az emésztményeket LC-MS/MS analízisnek vetettük alá Thermo LCQ-Fleet ioncsapda készülékkel. Az adatokat a Mascot Distiller (v2.1.1.0) szoftverrel dolgoztuk fel, majd a saját Mascot (v2.2.04) szerveren kerestük le a teljes NCBInr 110610 adatbázisban (14324397 szekvencia), csak Proteobaktéria-csoportra (1338715 szekvencia). 0,6 Da pontosságot használtunk a prekurzorra és 1 Da pontosságot a fragmens ionokra, két kihagyott hasítóhelyet engedélyezve. A szignifikanciahatárt a csak proteobaktéria szekvenciákra való lekeresés alapján a 47-es pontszámnál húztuk meg.

7. kísérlet: NCR247 lehetséges kölcsönható partnereinek azonosítása S. meliloti baktériumból (ezüst-festés, 1D-gél) 
A gélcsíkokat színtelenítés, redukálás és alkilezés után tripszinnel emésztettünk 4 órán át. Az emésztményeket LC-MS/MS analízisnek vetettük alá Thermo LCQ-Fleet ioncsapda készülékkel. Az adatokat a Mascot Distiller (v2.1.1.0) szoftverrel dolgoztuk fel, majd a saját Mascot (v2.2.04) szerveren kerestük le a teljes Swissprot adatbázisban (Sprot 20110502, 528048 szekvencia), illetve a saját adatbázisban, ami (SM1021_MT_NCR MT_NCR, 22623 szekvencia). 0,6 Da pontosságot használtunk a prekurzor ionra és 1 Da pontosságot a fragmens ionokra. A szignifikanciahatárt a saját adatbázisban való lekeresés alapján a 29-es pontszámnál húztuk meg.

8. kísérlet: NCR247 lehetséges kölcsönható partnereinek azonosítása S. meliloti bakteroid mintából (oldat)

Strep-taggel ellátott NCR247 együttható partnereinek keresése, A17 M. truncatula és S. meliloti (Sm1021) szimbiózisából létrejött gümőből származó bakteroid extraktumból. Az elúciós pufferben feltárt bakteroid extraktum pull-down kísérlet utáni mennyisége $250 \mu \mathrm{L}$ volt, fehérjetartalma $0.25 \mu \mathrm{g} / \mu \mathrm{L} .10 \mu \mathrm{g}$ összfehérjét tartalmazó oldatot beszárítottuk, majd denaturálás, redukálás és alkilezés után Promega oldallánc-védett tripszinnel oldatban emésztettük. A lehetséges kölcsönható partnereket tartalmazó bakteroid-mintából származó triptikus peptid-elegy LC-MS/MS analízise Thermo Orbitrap Elite tömegspektrométerrel történt (Thermo Fischer Scientific), az adatokból Pava_30sep2010 programmal készített csúcslistákat a ProteinProspector BatchTag Web adatbázis kereső programmal (v 5.3.0.) analizáltuk. Az adatokat a ProteinProspector teljes adatbázisban és a saját adatbázisunkban kerestük le, ami $S$. meliloti, M. truncatula fehérjéket és NCR-peptideket tartalmazott (190155 fehérje). 0,6 Da pontosságot használtunk a prekurzorra és 1 Da pontosságot a fragmens ionokra, 2 kihagyott triptikus hasítóhelyet engedélyezve. Elfogadási paraméterek: Minimum protein score: 20, minimum peptid score: 15 , maximum $\mathrm{E}$ value protein: 0.01 , peptid: 0.05 . 


\section{Eredmények és diszkusszió}

\subsection{Előzetes szeparálásra irányuló kísérlet}

A legnagyobb kezdeti kihívást az jelentette, hogy nem tudtuk, hogy az NCR peptidek milyen mennyiségben lehetnek jelen a bakteroidokban. Azaz nemcsak azzal a problémával kellett megküzdenünk, hogy olyan relatíve kicsi polipeptidekre vadászunk, amelyek talán csak 1-2 detektálható triptikus peptidet $\left(\mathrm{MH}^{+} \sim 800-2500 \mathrm{Da}\right)$ produkálnak (komplex fehérje elegyeket rendszerint triptikus emésztmények analízisével vizsgálunk), hanem félő volt, hogy a bakteriális fehérje ,háttér” mellett ezeket a növényi eredetű komponenseket nem is fogjuk tudni detektálni.

A mintában található, számunkra fontos NCR peptidek két jellemző tulajdonsága a kis méret és a relatíve magas cisztein-tartalom, ezért eleinte ezekre a jellemzőkre fókuszálva próbáltuk a komplex mintából izolálni őket. Szintetikus NCR-peptidekkel végzett előkísérleteink során próbálkoztunk N-acetil-DL-homocisztein-2-piridil-diszulfid és brómecetsav-2-klórtritil észter gyantákkal dúsítani a ciszetin-tartalmú peptideket a mintában, de ezek nem váltották be a hozzáfüzött reményeket. Rövid tisztítással kinyert bakteroid mintákkal végeztük további elökísérleteinket. A tömegspektrometriáról szóló fejezetben már említettük a Cys-specifikus, kvantitatív összehasonlításra is alkalmas ICAT-módszert [Gygi 1999], de kísérleteink eredményeire alapozva ezt is elvetettük, ugyanis vagy emésztés előtt kellett volna halászni (és akkor sok fehérjét kifogtunk volna, sok háttér peptiddel), vagy pedig emésztés után, de akkor csak a Cys-tartalmú darabokat kaptuk volna meg, ezen kívül céljainkhoz nem találtuk elég érzékenynek, nem csökkenti eléggé a növényi és bakteriális fehérje hátteret és ez egy meglehetősen drága módszer, ezért elvetettük. Relatíve kis polipeptidjeink méret szerinti szeparálására kezdetben különböző moláris tömegnél elválasztó membránokkal (Amicon Ultra centrifugal filters, Millipore) kísérleteztünk. Az eredmények azt mutatták, hogy ezzel a módszerrel sikerült ugyan csökkenteni a minta komplexitását, de mindeközben az NCR peptidjeinket is elveszítettük.

Ezt követően úgy döntöttünk, hogy a fordított fázisú (C18) oszlopon való elválasztással próbálkozunk. Hipotézisünk az volt, hogy a nagyobb fehérjék talán irreverzibilisen kikötnek a C18-láncokkal ellátott oszlopon, a kisebb fehérjéket azonban az oszlop átengedi. Ezért a mintában található NCR peptidek dúsítására OMIC C18 töltetü pipetta-hegyeket használtunk. 
Kontroll kísérletként ugyanezen mintákból szeparálás nélküli (teljes minta) emésztés, majd fehérjeanalízis is történt. A feltárt bakteroidok szuszpenziójából fehérjemérés után a C18-as és a teljes minta esetén is ugyanannyi fehérjemennyiséget $(50 \mu \mathrm{g})$ használtunk analízisre. A C18-as elválasztást követő lépések mindkét mintánál tökéletesen megegyeztek: a diszulfid-hidakat redukáltuk, a szabad szulfhidrileket alkileztük és végül tripszinnel emésztettük a mintákat. A C18-as elválasztás következtében fellépő fehérje-koncentráció csökkenést úgy igyekeztünk kompenzálni, hogy fele annyit injektáltunk a „teljes” emésztményből az LC-MS/MS-analízisre. A kísérletet egy biológiai minta egymást követő három technikai ismétlésével végeztük el. A C18-on frakcionált és a teljes minta eredményeit összehasonlítva arra voltunk kíváncsiak, hogy az elözetes elválasztással vagy a teljes minta analízisével detektálhatunk-e több NCR peptidet. A kísérletekben a $10 \mathrm{kDa}$ alatti polipeptideket egyetlen azonosított és manuálisan ellenőrzött peptidtalálattal is elfogadtuk, míg az ennél nagyobb méretủeket minimum 2 szignifikáns peptiddel tekintettük elfogadhatónak. Az összehasonlítás eredményeként azt láttuk, hogy kb. 15\%-al több fehérjét detektáltunk a teljes emésztményben, de kb. 30\%-al több NCR peptidet (13. ábra).
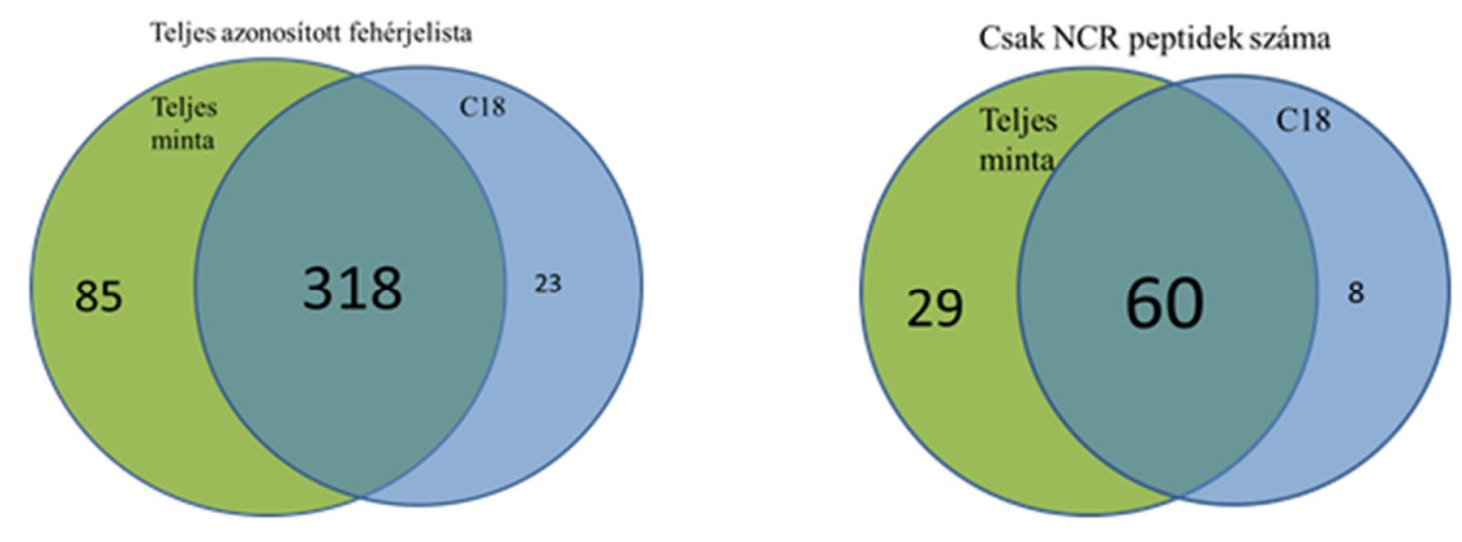

13. ábra: Teljes és C18-oszlopon frakcionált minták fehérje-találatainak összehasonlítása

Ennek alapján úgy döntöttünk, hogy a továbbiakban frakcionálatlan bakteroid-lizátummal dolgozunk.

4.2. Intakt és tisztított gümők fehérjetartalmának LC-MS/MS analízise, NCR peptidek azonosítása 
Kísérleteink során S. medicae (WSM419) baktériummal fertőzött $M$. truncatula A17 gümömintákat vizsgáltunk. Háromféle biológiai minta analízisét ismertetjük itt. A teljes gümő nyilvánvalóan tartalmazza az összes jelenlévő NCR peptidet, de hatalmas növényi és bakteriális háttérrel. A rövid tisztítás egy a differenciálódás minden fokát felvonultató elegyet ad, a Percollgrádiens centrifugáláson végzett tisztítás pedig a teljesen átalakult bakteroidokhoz vezet. A gümőkből két független mintát vizsgáltunk, de technikai ismétlésekkel; a bakteroid keverékekből hármat-hármat, technikai ismétlés nélkül. Az emésztési elegyeket csupán on-line frakcionáltuk. A bakteroid minták NCR tartalmát összehasonlítottuk nemcsak az MS/MS alapú azonosítást figyelembe véve, hanem a pontos tömeget és retenciós időt kihasználva megkerestük a megfelelő molekula-ionokat akkor is, ha azokból nem készült CID spektrum. Ezt a megközelítést azért választottuk, mert kémiai vagy izotópos jelölés nélkül így lehet megbizonyosodni bizonyos komponensek jelenlétéről vagy hiányáról anélkül, hogy előre elhatároznánk, mely komponensek érdekelnek bennünket.

\subsubsection{Eredmények}

A két intakt gümő mintából a technikai ismétlésekkel összesen közel 300 fehérjét tudtunk azonosítani, ezeknek több mint a fele növényi eredetü volt, 109 fehérje származott a baktériumból, a növényi fehérjék közül 45 volt NCR peptid (Függelék 2. és 3. táblázat).

A rövid tisztítási eljárás után kapott mintákból, a három független biológiai mintát együttvéve, az azonosított fehérjék száma megközelítette a 600 -at, ennek 2/3-a bakteriális fehérje volt, a növényi fehérjék közül 118 volt NCR protein (Függelék 4. és 5. táblázat). Az intakt gümőből származó NCR-ek mindegyikét azonosítottuk a rövid tisztítás utáni mintákból is, 4 peptidet azonban csak MS és retenciós idő alapján találtunk meg.

A Percoll-grádiensen való fehérjetisztítás eredményeként az érett, nitrogén-fixáló bakteroidból, a három egymástól független minta eredményeit együtt kezelve 313 bakteriális fehérjét és 103 növényi eredetű fehérjét azonosítottunk, ebből már 75 volt NCR (Függelék 6. és 7. táblázat).

Mivel a röviden tisztított minták a bakteroidok érése szempontjából „,vegyesek” voltak, a Percollgrádiensen tisztított minták viszont csak az érett bakteroidokat tartalmazták, ezért az elképzelésünk az volt, hogy a különböző mintákban találunk olyan egyedi NCR peptideket, amelyek vagy az átalakulás korai szakaszához, vagy inkább az érett, tejesen transzformált 
bakteroidokhoz rendelhetök. Rendelkezésünkre álltak transzkriptomikai adatok [Sinharoy 2013] arra vonatkozóan, hogy bizonyos vizsgált szimbiótikus fehérjék expressziója a gümőben hogyan változik a gümő érése folyamán (Függelék 1. táblázat). Köztudott azonban, hogy a génexpressziós adatok és a mintákból azonosított fehérjék között több ok miatt sem lehet egyértelmű párhuzamot vonni, ezért kíváncsiak voltunk arra, hogy a körülbelül 560 lehetséges NCR peptid közül az érés során mikor és melyek határozzák meg a szimbiótikus baktérium differenciálódását. Miután az automatikus adatgyüjtés során a prekurzor ion kiválasztása némiképp esetleges, ezért a két tisztítási eljárásból származó NCR-készlet összehasonlításakor nem támaszkodhattunk kizárólag a CID-alapú azonosításokra, emiatt választottuk az MS- és retenciós idő-alapú adat-összehasonlítást.

A 3 ,röviden” és a 3 Percoll-grádiensen tisztított mintákból összesen 338 különböző, NCR peptidet azonosító peptid-szekvenciát detektáltunk. A 6 LC/MS file NCR-tartalmának összehasonlításához egy referencia-listát készítettünk (3.9.1.3). Az MS-adatokat a fitXIC program segítségével [Guan 2011] vetettük össze az elkészített referencia listával (3.9.1.3) (Függelék 9. táblázat). Egy NCR peptidet abban az esetben tekintettünk a preparálási eljárás szempontjából egyedinek, ha legalább egy triptikus peptidje minimum két ismétlésben detektálható volt, és a másik preparálási eljárás LC-MS kísérleteiben egyszer sem volt detektálva. Ezen kritériumok alapján az alábbi 12 NCR peptidet csak a „rövid” tisztítási eljárással izolált bakteroid elegy tartalmazta, míg 5 NCR peptid csupán az érett bakteroid elegyben volt megfigyelhető (1. táblázat).

\begin{tabular}{|l|l|}
\hline $\begin{array}{l}\text { Csak a "rövid" tisztítási eljárás } \\
\text { után azonosított NCR-ek }\end{array}$ & $\begin{array}{l}\text { NCR010, NCR074, NCR097, NCR122, NCR152, NCR153, } \\
\text { NCR163, NCR167, NCR230, NCR306, NCR428, G7KA15 }\end{array}$ \\
\hline $\begin{array}{l}\text { Csak a Percoll-grádiensen } \\
\text { tisztított mintákból azonosított } \\
\text { NCR-ek }\end{array}$ & NCR005, NCR069, NCR286, NCR362, NCR526 \\
\hline
\end{tabular}

1. táblázat: A tisztítási eljárások alapján különbségként azonosított NCR peptidek listája 
Összességében 138 NCR peptidet tudtunk ezekből a kísérletekből azonosítani (Függelék 8. táblázat), izoelektromos pontjuk 3.41 és 9.62 között mozog, ez alapján 86 NCR anionos (pI $<6.5)$, 10 semleges $(6.5<\mathrm{pI}<7.5)$ és 42 kationos peptidként kategorizálható.A bevezetőben már említettük, hogy az NCR peptidek egy relatíve konzervatív N-terminális szignál-szekvenciával rendelkeznek [Alunni et al 2007]. A szignál-szekvencia feladata, hogy a peptidet az endoplazmatikus retikulumba irányítsa, ahol a szignált enzim vágja le a peptidről. Két különböző programot próbáltunk ki, hogy az érett NCR peptidek N-terminálisát, avagy a szignál peptid pontos hosszát megjósoljuk, a PrediSi [Hiller 2004] and SignalP 4.1 [Petersen 2011] programokat, és a második bizonyult megbízhatóbbnak, de 24 esetben a SignalP program sem tudta az enzimes hasítás helyét megjósolni. Az általunk azonosított 138 NCR peptid felének sikerült az N-terminális végét detektálni, néhány peptid esetében teljes szekvencia-lefedettséget értünk el. 5 esetben nem a program által megjósolt N-terminális szekvenciát azonosítottuk (14. ábra, Függelék 9. táblázat). Az összefoglaló táblázat tartalmazza az azonosított NCR peptidek teljes szekvenciáját, melyben kisebb betűmérettel jeleztük a megjósolt szignál szekvenciát.

NCR154: MVLFFSLLIVVINIDAYRSCKTDDDCPDYLCTSPKIGKCMDNDCYCI 


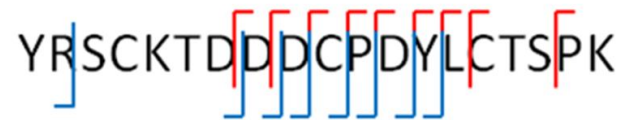
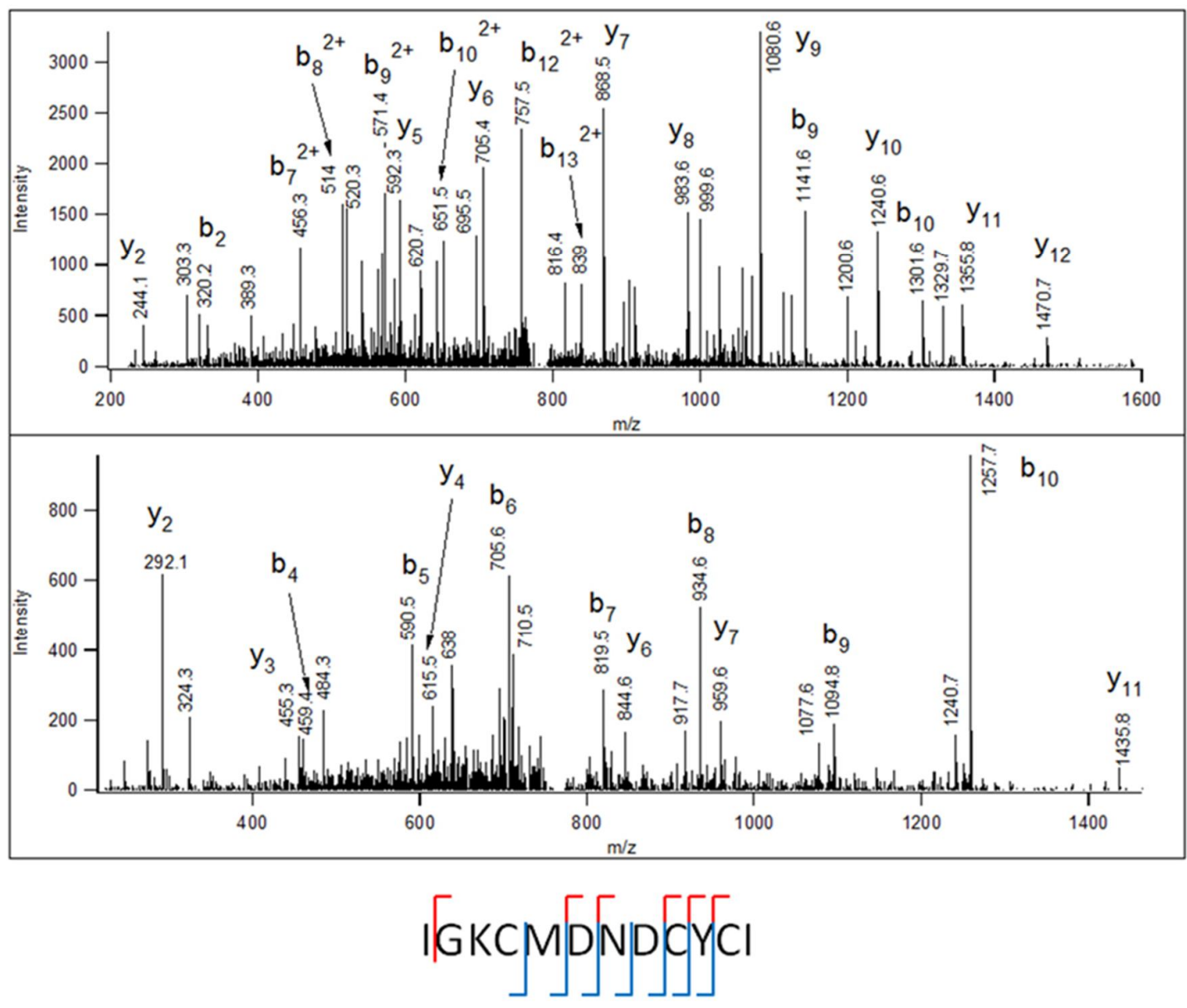

14. ábra. Egy példa, amikor a CID adatok teljes szekvencia lefedettséget biztosítottak. 


\subsubsection{Diszkusszió}

A Medicago-által termelt NCR peptidek az endoszimbiontákba kerülve esszenciális szerepet töltenek be azok nitrogénkötő bakteroidokká történő átalakulásában, hiányukban ez a differenciálódás nem jön létre. Ezt demonstrálja az M. truncatula dnf1-1 növényi mutáns is, melyből a szignál-peptidáz komplex gümő-specifikus egysége hiányában az NCR peptidek benn maradnak az endoplazmatikus retikulumban, s nem jutnak el a baktériumokba.

A jelen munkánk elött kevesebb, mint 10 tömegspektrometriával azonosított NCR peptid volt ismert, kérdés volt tehát, hogy mely NCR-kódoló gén terméke jelenik meg fehérjeszinten a gümőben és ezek hogyan befolyásolják a baktérium életfolyamatait. A korábbi kutatások valószínűleg azért sem közöltek NCR peptideket, mert a fehérjék elválasztására alkalmazott 1D SDS-PAGE gélen történő frakcionálás során a kisméretű peptidek "elvesztek" [Zhang 2006]. Több publikáció is foglalkozik a Medicago-fehérjékkel [Bestel-Corre 2002, Larrainzar 2007, Rose 2012, Volkening 2012], de jobbára a gyökér fehérjetartalmát vizsgálták, itt azonban csak egy, az NCR122 volt kimutatható, mely a többitől eltérően bakteriális fertőzés nélkül, a gyökérben is megtalálható. Az NCR peptidek igazi és kizárólagos helye a gümő, több száz NCR gén expresszálódik a szimbiotikus sejtben, és a szintetizált NCR peptidek különböző kombinációi vezénylik a differenciálódás folyamatát, egymás utáni fázisait. Ahhoz, hogy egy indeterminált gümő lehető legteljesebb bakteroid tartalmát vizsgálhassuk olyan módon kellett a gümőböl kinyerni őket, mellyel nemcsak a teljesen differenciálódott, hanem a részleges átalakuláson átesett bakteroidokhoz is hozzá juthassunk. Ennek okán alkalmaztuk a Percoll-grádiens elválasztás előtt az általunk csak „rövid”-nek nevezett tisztítási eljárást.

Vizsgálataink során $50 \mu \mathrm{g}$ fehérje triptikus emésztéséből kiindulva off-line francionálás nélkül, 2 órás grádienssel LC-MS/MS analízisnek vetettük alá mintáinkat. Ugyanazokat a mintákat két különböző preparációs eljárással és 3 biológiai ismétléssel vizsgáltuk. A rövid tisztítási eljárásnál a mérések között hetek-hónapok teltek el, míg a "Percoll" tisztított minták esetén ugyanakkor végeztük az analízist (,in-parallel”). A "rövid” tisztított minták esetén tehát okozhat valamennyi eltérést a detektált fehérjék minőségében vagy mennyiségében az is, hogy a minta preparálása és az LC-MS mérés nem rövid időn belül követték egymást. 
Az izolálatlan gümőből detektált fehérjéknek több, mint fele növényi eredetű volt, ezek között 45 NCR peptidet is azonosítottunk (ez $25 \%$-a az azonosított növényi fehérjéknek). Az NCR-ek relatíve magas aránya azt sugallja, hogy ezek a fehérjék nagy koncentrációban lehetnek jelen a gümőben, ezt alátámasztja génjeik magas transzkripciós aktivitása is. A "rövid" tisztítás eredményeképp a növényi eredetü fehérjék nagy részét sikerült eltüntetni a mintából, ebből következően a detektált NCR-ek száma több mint kétszeresére nőtt, és arányuk a növényi fehérjék között 50\%-ra emelkedett. Az azonosított fehérjék nagy része ez esetben már az endoszimbiontából származott. Ezekben a preparátumokban szintén megtaláltuk mindazokat az NCR peptideket, amelyeket az elválasztás nélküli gümőmintában is láttunk. A Percoll grádiensen történő tisztítás eredményeként az azonosított növényi fehérjék száma tovább csökkent, és a „maradéknak” közel 75\%-a NCR peptid volt, még a legabundánsabb gümő-fehérje, a leghemoglobin is eltünt az elegyböl.

A röviden tisztított, baktérium-keveréket tartalmazó mintákban talált egyedi NCR-ek (12 peptid) jobbára korai expressziót mutatnak, de néhány közülük a későbbi gümő-stádiumra jellemző. Ettől függetlenül valószínüleg valamennyi az átalakulás korai szakaszában játszik szerepet. A „rövid” tisztításra egyedinek talált NCR-ek közül annak a hatnak a transzkripciós aktivitását vizsgáltuk meg tüzetesebben, amelynek a Függelék 1. táblázatában csak egyféle mért transzkripciós adatát találtuk meg. Ezeket az adatokat összefoglalva a 2. táblázat tartalmazza.

\begin{tabular}{|l|r|rr|r|}
\hline NCR ID /koraiak? & Nod zone2 & Nod A17 6dpi & Nod 10dpi & \multicolumn{1}{l|}{ Nod 14dpi } \\
\hline NCR097 & 4523 & 7304 & 7898 & 7079 \\
\hline NCR152 & 3623 & 8153 & 922 & 2374 \\
\hline NCR153 & 5731 & 8394 & 9051 & 8433 \\
\hline NCR163IMGA|Medtr3g033955.1 & 6682 & 10715 & 5354 & 5210 \\
\hline NCR167IMGA|Medtr7g027120.1 & 2140 & 5455 & 7430 & 6159 \\
\hline NCR230 & 5134 & 9089 & 5710 & 4912 \\
\hline
\end{tabular}

2. táblázat. Csak "rövid" tisztításból azonosított NCR peptidek transzkripciós aktivitása (Sinharoy).

Ezekre az NCR-ekre azt várnánk, hogy a transzkripciós aktivitásuk a gümőfejlődés korai szakaszában (a leszedett gümők korához képest korábbi szakaszában) magasabb. Ezen peptidek közül az NCR152, NCR230 és föképp az NCR163 aktivitása mutatja is ezt a korai magasabb aktivitást, de a táblázatban található többi NCR aktivitása 6 napos és 14 napos gümőben 
nagyjából azonos szinten marad. Az aktivitás mértékét szinezéssel is jelöltük: zöld-sárga-piros szín jelzi az alacsony-közepes-magas aktivitást.

A Percoll-grádiensen tisztított minta NCR-tartalmából öt volt, amelyek csak erre a mintaelőkészítési elárásra bizonyultak egyedinek. Ebből az ötből három esetében volt transzkripciós aktivitás mérve, ezekböl az NCR005 eredményeit nem tettem be a táblázatba (kétszer volt mérve).

\begin{tabular}{|l|r|r|r|r|}
\hline NCR ID /későbbiek? & Nod zone2 & Nod A17 6dpi & Nod 10dpi & Nod 14dpi \\
\hline NCR069IMGA | Medtr6g043650.1 & 7929 & 8756 & 5163 & 4172 \\
\hline NCR362IMGA| Medtr3g028380.1 & 825 & 84 & 240 & 200 \\
\hline
\end{tabular}

3. táblázat. Csak Percoll-tisztítás után azonosított NCR peptidek transzkripciós aktivitása.

A 3. táblázat azt mutatja, hogy nem azért találhattuk ezeket az NCR peptideket egyedinek a Percoll-tisztítás után, mert késői fehérjék, hanem ennek más, valószínűleg a minta előkészítéséből vagy mérésből eredő oka lehet (minta komplexitás). Két adat azonban egyáltalán nem alkalmas messzemenő következtetések levonására, további kutatásokra volna szükség a kérdés tisztázására.

A táblázatban szereplő NCR-ek közül a legtöbb olyan, amelyeket transzkripciós adatok alapján detektálni kellett mind a korai, mind a későbbi gümőállapotban. Egy ilyen példa az NCR264, mely 6 napos vad típusú gümőben nagyon magas szintű transzkripciós aktivitást mutat, de még 14 naposban is igen aktív (4.A táblázat).

\begin{tabular}{|l|r|r|r|r|}
\hline NCR ID & Nod zone2 & Nod A17 6dpi & Nod 10dpi & Nod 14dpi \\
\hline NCR264 & 10150.4 & 10278.8 & 2538 & 5704 \\
\hline
\end{tabular}

4. A táblázat: NCR264 transzkripciós aktivitása vad típusú gümőben mérve.

NCR264 fehérjeszintű megjelenését a kvantitatív adatelemzés során sikerült nyomon követni, és azt találtuk, hogy míg a kevert bakteroid-állapotokat tartalmazó mintákból két peptidjét 2-2 esetben detektáltuk, addig a differenciálódott bakteroid mintákban csak az egyik peptidet és csak egy esetben azonosítottunk a három biológiai ismétlésből. 
A 4.B táblázat pedig egy olyan esetre mutat példát, ahol az NCR peptid a gömőfejlödés későbbi szakaszában mutat magasabb génaktivitást, és ezt a kvantitatív adatok is iagzolják: egy peptiddel detektáltuk ezt a fehérjét, eme peptidjét a „Rövid” tisztítás után egy, Percoll-grádiens centrifugálás után mindhárom biológiai mintában detektáltuk.

\begin{tabular}{|l|l|r|r|r|}
\hline NCR ID & Nod zone2 & Nod A17 6dpi & Nod 10dpi & Nod 14dpi \\
\hline NCR157 & 309.985 & 4561.61 & 11653.3 & 10517.3 \\
\hline
\end{tabular}

4. B táblázat: NCR157 transzkripciós aktivitása.

Transzkriptom-adatokkal összevetve ezeket az eredményeket tehát azt mondhatjuk, hogy a fehérjeszinten „egyedinek” talált NCR-ek esetén a fehérjéket kódoló gének expressziója a fehérjeszinten való detektálhatóság között nem találtunk egyértelmü korrelációt, de sok esetben mégis összecsengenek a transzkriptom és proteom eredmények egymással, azaz pro és kontra találtunk bizonyítékokat. A jelen példákkal azt szerettük volna nyomatékosítani, hogy nem minden esetben támasztják alá egymást a génszintü és a fehérjeszintü eredmények, de az semmiképp sem igaz, hogy cáfolnák egymást, két módszert célszerü együtt, de a megfelelő fenntartásokkal alkalmazni. Az érett bakteroidokban kimutatott 5 ,egyedi” NCR peptidnek jelen kell lennie a keverékben is, hisz abban is találhatók teljesen transzformált baktériumok, de relatív mennyiségük valószínűleg alacsony ezért nem detektáltuk őket. Feltehetően ezek az NCR peptidek az érett baktériumok müködésében játszanak szerepet. Az NCR005 és NCR069 peptidek megjelenése csak a Percoll-tisztított mintákban meglehetősen meglepő volt számunkra, mert génexpresszió alapján ezek az NCR peptidek a korai fehérjék közé tartoznak, bár jelenlétük magyarázható lehet ezen polipeptidek nagy stabilitásával és hosszú életidejével.

Izoelektromos pont alapján az azonosított NCR-ek nagyjából 2/3-a anionos karakterü, azaz savas jellegü $(\mathrm{pI}<6)$ volt. Az anionos peptidek bejutva a baktériumba annak citoplazmájában lokalizálódnak [Van de Velde 2010]. Az anionos peptidek esetén még nem ismert, hogy azok milyen módon jutnak be a baktériumba és mi a konkrét szerepük, de nagy számuk a gyökérgümőkben arra enged következtetni, hogy a bakteriális differenciálódás folyamatának tényleges irányításában komoly szerepet játszhatnak.

Az azonosított NCR-ek sokkal kisebb hányada volt kationos, azaz bázikus tulajdonságú ( $\mathrm{pI}>8$ ). Ismert, hogy a kationos NCR peptidek a baktériumok membránjával lépnek kölcsönhatásba 
(korábbi munkáinkban két erősen kationos és egy anionos NCR peptiddel vizsgáltuk ezt az interakciót [Van de Velde 2010, Farkas 2014]). Az eddig vizsgált magas IEP-vel rendelkező peptid (NCR247, NCR335) drasztikus hatást mutatott a baktériummal szemben. Elképzelhető, hogy mivel a növény csak átalakítani kívánja a baktériumot és nem elpusztítani, ezért lehet a majdnem 600 peptidből kevesebb a kationos és még kevesebb számú az erősen kationos. Feltételezhető továbbá az is, hogy a nagyon erősen toxikus NCR-ekből a növény mennyiségileg is sokkal kevesebbet termel, ezek a többi peptiddel együttmüködve hasznosulnak. Ez magyarázatként szolgálhat arra is, hogy miért nem azonosítottuk még soha a bakteroidokból az NCR247 (pI: 10.15) vagy NCR335 (pI: 11.22) peptideket.

\subsection{Vad és mutáns növényből származó gyökérgümők fehérjeszintű analízise, a minták fehérje-tartalmának és NCR peptid tartalmának szemikvantitatív összehasonlítása}

\subsubsection{Rövid bevezetés}

A $M$. truncatula $6 \mathrm{~V}$ mutáns genomjából egy $\sim 50$ kilobázis méretü rész hiányzik. Fenotípusában is eltérő a vad típustól: kisebb méretủek és sárgák a növénykék, gümöik kisebbek és fehér színűek, bár mennyiségük általában jelentős a gyökéren. Ugyanakkor ez a mutáns nitrogénkötésre nem képes. A Kaló-csoport vizsgálatai igazolták, hogy egyedül az NCR169 gén hiánya felelős ennek a fenotípusnak a kialakulásáert [személyes kommunikáció]. Transzkriptomikai vizsgálatok bebizonyították, hogy a 6V mutánsban a nitrogenáz enzim alegységei up-reguláltak, a Molibdén szint alacsony. Az NCR169 lehet talán az első NCR peptid, amelynek funkcióját sikerült meghatározni. Kutatásunk arra irányult, hogy milyen, a fehérjekészletben megmutatkozó különbségek lehetnek a vad típusú és a 6V mutáns növényekben és az azokkal kölcsönható baktériumokban, mely fehérjék lehetnek szignifikánsan nagyobb mennyiségben jelen az egyik vagy másik genotípusban, és mely fehérjék hiányoznak belölük a másik genotípushoz viszonyítva. Ezekből a fehérjeszintű különbségekből arra szerettünk volna útmutatást találni, hogy mely bakteriális folyamatokat befolyásol a növényi NCR169 jelenléte, amelynek hiányában a baktériumok differenciálódása, és ebből adódóan későbbi nitrogénkötő képessége is defektust szenved. 


\subsubsection{Eredmények}

Vizsgálataink során a vad (WT vagy A17) és mutáns (továbbiakban 6V vagy mut.) M. truncatula növény $S$. medicae WSM419 baktériummal fertőzött gümőiböl (15 napos gümők) rövid tisztítási eljárással izolált bakteroidok fehérjetartalmát vizsgáltuk. Három párhuzamos biológiai mintánk volt: különböző, de páronként azonos időpontban vetett WT és $6 \mathrm{~V}$ növényekből gyüjtött gümők fehérjetartalmát vetettük össze. Egységesen $50 \mu \mathrm{g}$ fehérjét emésztettünk oldatban mindegyik mintából, és a második biológiai kísérletből, kb. $20 \mu \mathrm{g}$ fehérjéből Coomassie-festett 1D-SDS gél is készült. A minta-előkészítés folyamatát, a triptikus elegyek LC-MS/MS analízisét, majd az adatok értelmezését az 3.9.2 fejezetben ismertettük. Itt annyit emelnék ki, hogy az oldatban emésztett minták esetében három-három 120 perces LC-MS analízis eredményét „füztük egybe”, míg a gél 12 darabra lett osztva, és az egyenként 60 perces LC-MS futásból származó adatokat kezeltük egy mintaként. Az itt ismertetett fehérje-azonosítási adatok 1.4\% alatti FDR szintet képviselnek minden minta esetében.

A minták összehasonlítását spektrum-számlálás alapján végeztük. Abból indultunk ki, hogy a jelenlévő fehérjék zömének mennyisége nem változik, így elegendő a vizsgált fehérje-elegy összetételének jelentősebb változásaira koncentrálnunk. Kiszámítottuk valamennyi mintára külön-külön, hogy egy adott fehérje mekkora részt képviselt az azonosított peptidek között. Az adott fehérjét azonosító spektrumok számát elosztottuk az adott mintában azonosított összes spektrumok számával. (Függelék 10. táblázat: részletes adatok). Azt hogy egy fehérje mennyisége mennyiben különbözik a vad típusú és mutáns növények között a WT/mut hányados tükrözi, ezt pedig úgy kaptuk, hogy elosztottuk a fehérje WT relatív mennyiségét képviselő számot a $6 \mathrm{~V}$ elegyben relatív mennyiséget jelölö értékkel. A medián érték erre a hányadosra páronként $\sim 1$, ami azt jelzi, hogy a fehérjék zöme változatlan mennyiségben volt jelen a különböző gümő-preparátumokban. A következő táblázatban ezeket a WT/mut arányokat hasonlítjuk egymáshoz a négy kísérletben (Függelék 11. táblázat). A globális összehasonlításhoz a különbségeket számszerüsíteni kellett. Így a csak a WT mintában megtalált fehérjékre vonatkozó értékeket egységesen 50-nek vettük, míg a csak a mutánsban megtalált fehérjék értékeit 0.001 -re ,állítottuk be”. A specifikusan egy mintához rendelés alapfeltétele az volt, hogy az adott fehérje minimum 10 spektrummal képviselve legyen abban a mintában, míg a minta 
párjában ne legyen fellelhető. Ha valamelyik fehérjét egy minta-párban nem detektáltunk, vagy csak a WT vagy a $6 \mathrm{~V}$ mintában volt jelen, de a különbség nem volt szignifikánsnak tekinthetö (lásd fentebb), akkor a megfelelő WT/mut rubrikába nulla került. A többi fehérjére természetesen a megfelelő arányszámokat tüntettük fel. Szignifikáns különbségnek a fehérje-szint 50\%-os változását tekintettük. Tehát amennyiben a WT/mut hányados 0.5 alatt volt (de minimum 0.001 ! lásd fentebb), úgy ennek a fehérjének a mennyisége nőtt a mutáció hatására, míg ha a hányados 1.5 feletti értéket mutatott, akkor ennek a fehérjének a mennyisége csökkent az NCR169 peptid hiányában.

A Függelék 12. és 13. táblázataiban a mintákban detektált bakteriális fehérjék szint-változását mutatjuk be két különböző szemszögböl. Azokat a bakteriális fehérjéket emeltük ki sárga színnel a 12. táblázatban, melyeknél az adott fehérje vagy nagyobb mennyiségben a mutáns mintában volt detektálható (0.002-0.5), vagy kizárólag a mutáns mintából volt kimutatható (0.001). Azokat a fehérjéket, amelyek a WT növény gümőjében voltak jelen nagyobb mennyiségben vagy kizárólagosan, azaz a mutáció hatására "eltüntek" zöld színnel emeltük ki a kísérletek eredményeiből (Függelék 13. táblázat). Azokat a bakteriális fehérjéket minősítettük változónak, amelyek a négy kísérletből legalább háromban azonos módon viselkedtek.

Tizenhat olyan fehérjét azonosítottunk a mintákban, amelyek határozottan nagyobb mennyiségben voltak jelen a mutáns növényekröl gyüjtött gümökben (5. táblázat). Ezek között pillanatnyilag szisztematikus összefüggést nem tudunk kimutatni. Némiképp több, 23 fehérje “tünt el” vagy mutatott jelentős csökkenést a mutáns gümőkben (6. táblázat), ezek között nem meglepően, számos nitrogén-fixálással nyilvánvalóan kapcsolatos fehérje található. 


\begin{tabular}{|c|c|c|c|c|c|c|}
\hline & in-sol 1 & in-sol 2 & in-sol 3 & in-gel & Protein & \\
\hline Acc \# & WT/mut & WT/mut & WT/mut & WT/mut & MW & Protein Name \\
\hline A6U878 & 0.231 & 0.337 & 0.298 & 1.033 & 16243 & $50 S$ ribosomal protein L15 \\
\hline A6UDP0 & 0.133 & 0.188 & 0.254 & 0.898 & 112280 & 2-oxoglutarate dehydrogenase, E1 subunit \\
\hline A6UKC3 & 0.472 & 0.495 & 0.488 & 0.877 & 80564 & Catalase-peroxidase \\
\hline A6UKJ7 & 0.393 & 0.346 & 0.118 & 0.692 & 45110 & Uncharacterized protein/Metallo-dependent phosphatase-like \\
\hline A6UBL8 & 0.247 & 0.382 & 0.025 & 0.563 & 27328 & Uncharacterized protein (Precursor)/potential kinase? \\
\hline A6U763 & 0.338 & 0.409 & 0.364 & 0.538 & 54589 & Protease Do (Precursor) \\
\hline A6UKK1 & 0.433 & 0.148 & 0.001 & 0.501 & 58020 & Extracellular solute-binding protein family 5 (Precursor) \\
\hline A6U6G0 & 0.621 & 0.458 & 0.307 & 0.491 & 55825 & Catalase \\
\hline A6UKK3 & 0.001 & 0.324 & 0.260 & 0.448 & 20899 & Uncharacterized protein \\
\hline A6UIK2 & 0.487 & 0.411 & 0.145 & 0.428 & 58972 & Extracellular solute-binding protein family 5 (Precursor) \\
\hline A6UIE4 & 0.216 & 0.223 & 0.325 & 0.409 & 17733 & Heat shock protein Hsp20 \\
\hline A6U9A5 & 0.452 & 0.001 & 0.031 & 0.371 & 52133 & Glutamine synthetase \\
\hline A6UD15 & 0.001 & 0.230 & 0.075 & 0.302 & 17428 & Heat shock protein Hsp20 \\
\hline A6UHV3 & 0.001 & 0.001 & 0.001 & 0.289 & 17767 & 3-demethylubiquinone-9 3-methyltransferase \\
\hline A6UBT9 & 0.001 & 0.262 & 0.001 & 0.196 & 63870 & 2-isopropylmalate synthase \\
\hline A6U794 & 0.001 & 0.001 & 0.001 & 0.030 & 37362 & Porin (Precursor) \\
\hline
\end{tabular}

5. táblázat. Bakteriális fehérjék, melyek M. truncatula 6V mutáns növény gümöiből szignifikánsan nagyobb mennyiségben kerültek azonosításra. A teljes lista a Függelék 12. táblázatában található.

\begin{tabular}{|c|c|c|c|c|c|c|}
\hline & in-sol 1 & in-sol 2 & in-sol 3 & in-gel & Protein & \\
\hline Acc \# & WT/mut & WT/mut & WT/mut & WT/mut & MW & Protein Name \\
\hline A6UME4 & 11.684 & 50.000 & 50.000 & 7.501 & 7695 & Uncharacterized protein/Putative nitrogen fixation protein \\
\hline A6UME8 & 3.029 & 3.884 & 10.701 & 6.706 & 56553 & Nitrogenase protein alpha chain \\
\hline A6UME3 & 2.505 & 5.027 & 6.148 & 6.564 & 11404 & Ferredoxin III 4(4Fe-4S) nif-specific \\
\hline A6UME5 & 0.000 & 50.000 & 50.000 & 4.376 & 17992 & Nitrogen fixation protein NifX \\
\hline A6UMF8 & 1.731 & 0.000 & 5.203 & 3.855 & 7657 & NifT/FixU family protein \\
\hline A6U870 & 0.433 & 50.000 & 1.951 & 3.215 & 11320 & $50 S$ ribosomal protein $\mathrm{L} 24$ \\
\hline Q52905 & 3.173 & 2.227 & 50.000 & 2.605 & 12281 & Nitrogen regulatory protein $\mathrm{P}$-II \\
\hline A6UME7 & 0.838 & 2.440 & 2.108 & 2.554 & 57692 & Nitrogenase molybdenum-iron protein beta chain \\
\hline A6U5E4 & 1.190 & 1.782 & 1.788 & 2.206 & 21202 & Sigma 54 modulation protein/ribosomal protein S30EA \\
\hline A6U7C3 & 2.596 & 1.336 & 1.951 & 2.110 & 31136 & MOSC domain containing protein \\
\hline A6UEC2 & 1.236 & 2.138 & 1.734 & 1.794 & 39630 & 3-isopropylmalate dehydrogenase \\
\hline A6U8K3 & 2.493 & 1.675 & 2.276 & 1.620 & 32060 & Elongation factor Ts \\
\hline A6UBN5 & 50.000 & 0.891 & 50.000 & 1.603 & 43521 & Aminotransferase class I and II \\
\hline A6UD23 & 50.000 & 50.000 & 50.000 & 1.600 & 65412 & Dihydroxy-acid dehydratase \\
\hline A6U6X1 & 2.308 & 1.782 & 0.217 & 1.587 & 28537 & DSBA oxidoreductase (Precursor) \\
\hline A6UF92 & 3.808 & 1.584 & 1.517 & 1.579 & 45172 & Peptidase M29 aminopeptidase II \\
\hline A6UMF4 & 50.000 & 4.306 & 5.365 & 1.406 & 10938 & FixX ferredoxin-like protein \\
\hline A6UCG6 & 1.904 & 2.970 & 1.765 & 1.281 & 42902 & Arginine biosynthesis bifunctional protein ArgJ \\
\hline A6U8K5 & 4.977 & 2.164 & 2.168 & 1.234 & 20819 & Ribosome-recycling factor \\
\hline A6UDZ1 & 50.000 & 2.004 & 4.877 & 1.229 & 34997 & Thioredoxin \\
\hline A6UMF3 & 50.000 & 4.276 & 50.000 & 1.125 & 47196 & FAD dependent oxidoreductase (Precursor) \\
\hline A6UF27 & 2.282 & 4.157 & 4.552 & 1.039 & 61997 & NusA antitermination factor \\
\hline A6U6Y9 & 3.173 & 2.227 & 1.821 & 0.850 & 51972 & Betaine aldehyde dehydrogenase \\
\hline
\end{tabular}


6. táblázat. Bakteriális fehérjék, melyek "eltüntek" a gyökergümőkből a mutáció hatására, azaz a vad típusú növényben voltak sokkal nagyobb mennyiségben detektálva. A teljes lista a Függelék 13. táblázatában található.

A növényi eredetü fehérjékröl is készítettünk hasonló összehasonlítást. Itt egyetlen táblázatban foglaltuk össze a különbségeket. Ugyanazt az elvet követtük, mint a bakteriális fehérjéknél, azaz azokat a fehérjéket fogadtuk el az egyik vagy másik genotípushoz kötődőnek, amelyek a négy kísérletből háromban azonos változást mutattak. (Függelék 14. táblázat, a szín-kód is azonos a bakteriális táblázatokban használttal). Érdekes, hogy növényi hisztonokat detektáltunk a mutánsokban feldúsulva (7. táblázat), míg a mutánsból hiányzó, azaz a vad-típusú növényben jelentősen nagyobb mennyiségben jelenlevő fehérjék egytől egyig SYMpep termékek, azaz NCR vagy GRP peptidek (8. táblázat).

\begin{tabular}{|l|r|r|r|r|r|l|}
\hline & in-sol 1 & in-sol 2 & in-sol 3 & in-gel & \multicolumn{1}{|l|}{ Protein } & \\
\hline Acc \# & WT/mut & WT/mut & WT/mut & WT/mut & MW & Protein Name \\
\hline I3T2G2 & 0.001 & 0.001 & 0.001 & 0.001 & 55120 & Uncharacterized protein/peptidase A1 family \\
\hline Q1S9I9 & 0.165 & 0.263 & 0.569 & 0.165 & 16224 & Probable histone H2B.1 \\
\hline Q1RU62 & 0.194 & 0.190 & 0.397 & 0.124 & 11410 Histone H4 \\
\hline G7I5Z5 & 0.151 & 0.146 & 0.253 & 0.153 & 15406 & Histone H3 \\
\hline Q1S053 & 0.087 & 0.001 & 0.325 & 0.228 & 16142 Probable histone H2A.3 \\
\hline B7FI14 & 0.001 & 0.001 & 0.001 & 0.001 & 37985 & Putative uncharacterized protein/Peroxidase \\
\hline
\end{tabular}

7.táblázat. Mutáns gümőkből szignifikánsan nagyobb mennyiségben detektált növényi eredetű fehérjék listája. 


\begin{tabular}{|l|r|r|r|l|l|}
\hline & in-sol 1 & in-sol 2 & in-sol 3 & \multicolumn{1}{l|}{ Protein } \\
\hline ACC\# & WT/mut & WT/mut & WT/mut & \multicolumn{1}{l|}{ MW } & Protein Name \\
\hline BRC896 & 50.000 & 50.000 & 50.000 & 23962 MtNodGRP3A \\
\hline BRC22 & 2.077 & 1.782 & 2.731 & 11936 NCR019 Medtr5g056185.1 \\
\hline BRC201 & 50.000 & 50.000 & 50.000 & 7403 NCR169 Medtr7g029760.1 \\
\hline BRC404 & 4.039 & 3.118 & 2.168 & 9174 NCR333 \\
\hline BRC69 & 3.029 & 2.895 & 50.000 & 6923 NCR059 Medtr8g064070.1 \\
\hline BRC517 & 50.000 & 50.000 & 4.552 & 6509 NCR429 Medtr4g059755.3 Medtr4g059755.2 \\
\hline BRC368 & 50.000 & 3.564 & 50.000 & 7102 NCR302 Medtr3g053600.1 \\
\hline BRC605 & 1.875 & 1.930 & 50.000 & 6647 Medtr1g075045.1 \\
\hline BRC272 & 2.596 & 2.138 & 2.168 & 7362 NCR225 \\
\hline BRC151 & 2.308 & 1.633 & 2.384 & 7032 NCR129 Medtr4g055680.1 \\
\hline BRC4 & 5.914 & 3.811 & 10.535 & 8232 NCR003 \\
\hline BRC79 & 50.000 & 50.000 & 50.000 & 7073 NCR068 Medtr6g055160.1 \\
\hline BRC298 & 2.308 & 2.418 & 50.000 & 7099 NCR245 Medtr6g006245.1 \\
\hline BRC109 & 2.019 & 2.025 & 50.000 & 7482 NCR094 Medtr5g055370.1 \\
\hline BRC103 & 50.000 & 50.000 & 50.000 & 7406 NCR088 Medtr5g063600.1 \\
\hline BRC261 & 50.000 & 50.000 & 50.000 & 6995 NCR216 \\
\hline BRC168 & 2.885 & 2.800 & 6.070 & 5870 NCR142 \\
\hline BRC104 & 4.003 & 2.153 & 2.991 & 8261 NCR089 Medtr5g061800.1 \\
\hline BRC96 & 2.596 & 3.564 & 2.601 & 8200 NCR081 Medtr5g072456.1 \\
\hline BRC670 & 50.000 & 50.000 & 50.000 & 8942 Medtr3g069870.1 \\
\hline
\end{tabular}

8.táblázat. NCR és GRP peptidek, amelyeket nem vagy csak szignifikánsan kisebb mennyiségben detektáltunk a $6 \mathrm{~V}$ mutáns gümőiben. Az azonosított növényi eredetű fehérjék teljes listája a Függelék 14. táblázatában látható.

\subsubsection{Diszkusszió}

Korábbi vizsgálatok alapján tudjuk, hogy a $6 \mathrm{~V}$ mutáns szimbioszómákban található bakteroidok nitrogénkötési képessége korlátozott (személyes kommunikáció, Kaló Péter). Kutatásaink a mutáció proteomikai hatásának feltérképezésére irányultak. Eredményeink fehérje-szinten is jól mutatják, hogy a $6 \mathrm{~V}$ mutáns bakteroidjaiban a nitrogén-fixálással valami nincs rendben. A nitrogén-kötéssel kapcsolatos fehérjéket, pl. NifT/FixU family protein, Ferredoxin III 4(4Fe-4S) nif-specific, Nitrogenase protein, Nitrogen fixation protein NifX stb. ezekben a mintákban reprodukálhatóan sokkal kisebb mennyiségben detektáltuk, mint a vad-típusú növény gümőiből. Az oldatban emésztett mintákból sok esetben kizárólag a WT genotípusban azonosítottuk ezeket 
a fehérjéket, míg a gélfuttatás eredményei azt jelzik, hogy a fehérjék a mutáns genotípus gümőiben is megtalálhatóak, de szignifikánsan kisebb mennyiségben, mint a vad típusban. Ez a megfigyelés a két megközelítés különbségére, a két módszerből származott eredmények összehasonlíthatóságának korlátaira irányítja a figyelmet. A gélben történő fehérje-frakcionálás mint első lépés lehetővé teszi, hogy „mélyebbre” ássunk a fehérje-elegyben, több komponens jelenlétét detektáljuk, és így több fehérjéről kapjunk pontosabb kvantitatív adatot. Ugyanakkor ez a módszer nem igazán megfelelő a szimbiózisban kulcsszerepet játszó polipeptidek detektálására, amelyek méretüknél fogva többnyire már jelen sincsenek az analizálandó mintában az SDSPAGE frakcionálás végére. Ezt sugallják a gümő-fehérjéket SDS-frakcionálás után leíró proteomikai adatok [Zhang et al 2006] és saját régebbi eredményeink is. Ezért is döntöttünk úgy, hogy az összehasonlítások során elsősorban oldatban emésztett minták összehasonlítására hagyatkozunk majd, viszont mindegyik elegyet háromszor vizsgáltunk meg azonos módon. Komplex elegyeknél a technikai reprodukálhatóság (hogy ugyanazok a prekurzor ionok lesznek kiválasztva MS/MS analízisre) 50-70\% [KF Medzihradszky, személyes kommunikáció]. Így jogosan remélhettük, hogy a három "technikai" ismétlés jelentősen javítja az elegyről rendelkezésre álló információk mennyiségét. Az előző fejezetben ismertetett adatok azt is igazolták, hogy az NCR peptidek olyan nagy mennyiségben vannak jelen a gümöpreparátumokban, hogy off-line frakcionálás nélkül is detektálni tudunk számos ilyen molekulát. Döntésünk helyességét támogatja az a megfigyelés, hogy bár legalább 20 NCR peptidet sikerült azonosítani a gél-mintából (Függelék 10. táblázat) az oldat-mintákból csaknem hétszer annyit tudtunk kimutatni. Összesen 139 NCR peptidet azonosítottunk a mintákból (Függelék 14. táblázat). Ezeknek csaknem a felét (68-at) kizárólag a vad típusú növény gümőiből sikerült kimutatni. Nem találtunk egyetlen olyan NCR peptidet sem, ami kizárólag a mutáns növényre lenne jellemző. A 139 NCR azonosított peptidből 94-et írtunk le az előző fejezetben. A hasonló, rövid tisztításból eredő mintákból viszont csak 118 NCR-t azonosítottunk az előző tanulmányban. A kisebb azonosítási szám oka lehet az, hogy az előző kísérlet-sorozatban a mintákból egyetlen LC/MS/MS kísérlet készült csupán. Ugyanakkor az a tény, hogy az ebben a kísérletben talált peptidek kb. harmadát nem azonosítottuk az előző kísérlet-sorozatban rávilágít az általunk választott stratégia hátrányára is, azaz arra, hogy off-line frakcionálás nélkül csupán az elegy “felső rétegét” pásztázzuk, és némiképp esetleges, hogy ennek a rétegnek az "aljából” mely komponenseket fogjuk azonosítani. Viszont miután mindkét kísérlet-sorozatban három-három 
különbözö biológiai mintát hasonlítottunk össze, és a technikai ismétlések alapján az eredmények reprodukálhatóak voltak, ez azt sugallja, hogy környezeti hatások és fóként a gümő "kora" jelentős befolyással bírnak az NCR-elegy összetételére.

Érdekes megvizsgálni transzkriptom szinten azokat az NCR peptideket, melyeket jobbára vagy kizárólag csak a vad típusú növényben találtunk meg, és azokat is, amelyek kimutathatóak voltak a mutáns mintákból is. Roux és munkatársai 2014-es cikkében a gümő különböző zónái szerint vizsgálták NCR peptidek génexpresszióját (10 napos gümőkben), ebben a kísérletben szerepelt az NCR169 is. Egy táblázatban foglaltuk össze Roux és mtsai génexpressziós táblázata alapján ezeket az eredményeket, a génexpresszió növekvő szintjét zöld-sárga-piros színnel jelezve (9. táblázat). Az NCR169 génje leginkább az Interzónában aktív. Gödöllői kooperációs partnereink bizonyították, hogy egyedül az NCR169 hiánya okozza a 6V mutáns fenotípusát, azaz azt feltételezhetjük, hogy:

a, az Interzónában elmaradó NCR169 expresszió és a termelődő fehérje hiánya okozza számos NCR peptid expressziójának csökkenését, ezáltal a nem megfelelő gümő-müködést és nitrogénkötést a mutáns növényben;

b, Azokat az NCR peptideket találhatnánk csak meg a 6V mutánsban, amelyek expressziós aktivitása az Interzóna előttre, a II. zóna distalis vagy proximalis régiójára tehető. Zöld színnel jelöltük a vad típusú növényben jelentősebb NCR-ek nevét, sárga színnel a mutánsban is nagyobb mennyiségben detektált NCR peptideket. 


\begin{tabular}{|l|rrrr|}
\hline NCR & Zone II dist & Zone II prox & Interzone & Zone III \\
\hline NCR169 & 5.6 & 116.0 & 3156.0 & 1799.0 \\
\hline NCR019 & 2.0 & 47.0 & 898.0 & 956.0 \\
\hline NCR333 & 0.5 & 39.5 & 386.0 & 74.0 \\
\hline NCR059 & 0.6 & 5.0 & 330.0 & 257.0 \\
\hline NCR429 & 3.0 & 242.0 & 417.0 & 395.0 \\
\hline NCR302 & 2.0 & 6.0 & 579.0 & 1233.0 \\
\hline Medtr1g075045.1 & 0.0 & 0.2 & 85.0 & 54.0 \\
\hline NCR129 & 5.0 & 612.0 & 2957.0 & 621.0 \\
\hline NCR068 & 62.0 & 409.0 & 43785.0 & 14077.0 \\
\hline NCR245 & 8.8 & 136.0 & 4603.0 & 3291.0 \\
\hline NCR094 & 6.4 & 572.0 & 1517.0 & 779.0 \\
\hline NCR088 & 2.0 & 193.0 & 783.0 & 624.0 \\
\hline NCR216 & 8.8 & 136.0 & 4603.0 & 3291.0 \\
\hline NCR089 & 1.8 & 45.0 & 675.0 & 436.0 \\
\hline NCR081 & 3.6 & 315.0 & 654.0 & 648.0 \\
\hline Medtr3g069870.1 & 7.7 & 219.0 & 5934.0 & 3053.0 \\
\hline NCR146 & 0.5 & 19.0 & 763.0 & 536.0 \\
\hline NCR101 & 2.0 & 95.3 & 1809.3 & 989.4 \\
\hline NCR007 & 48.9 & 2327.5 & 32167.0 & 14009.0 \\
\hline Medtr1g074860 & 3.7 & 934.7 & 953.0 & 111.0 \\
\hline NCR410 & 1.1 & 54.6 & 14.0 & 0.2 \\
\hline Medtr2g450280 & 1.2 & 150.0 & 37.6 & 0.3 \\
\hline
\end{tabular}

9. táblázat: Néhány NCR peptid génexpressziós aktivitása vad típusú növény 10 napos gümőjében zónák szerint vizsgálva [Roux 2014].

A felső 16 fehérje expressziós tendenciája azt mutatja, hogy azért lehetnek csak vagy jobbára a vad típusban jelen, mert főképp az Interzónában vagy a III Zónában expresszálnak, hiányuk tehát magyarázható az NCR169 hiányával. Az alsó 6 NCR közül az NCR146, 101 és NCR007 fehérjeszinten megtalálható volt a vad és a mutáns gümőkben is. Az NCR007 esetén ez magyarázható a viszonylag korai, II Zóna proximalis régiójában történő már magasabb génexpresszióval. Az NCR146 és NCR101 fehérjeszintű jelenlétét ezen adatokkal nem tudjuk indokolni. Az utolsó három NCR peptid fehérjeszinten a mutánsban szignifikánsabb volt, mint a vad típusú gümőben (de 1-1 esetben ott is azonosítottuk), ennek magyarázata lehet eme NCR peptideknek a színekkel jól illusztrálható inkább korai génaktivitása.

Eredményeinkre épülhetnek további biológiai és genetikai vizsgálatok, melyekkel együtt lehetségessé válhat majd a nitrogénkötés folyamatának pontosabb feltérképezése. 


\subsection{NCR247 növényi fehérje lehetséges kölcsönható partnereinek azonosítása Medicago truncatula A17 gümőkből izolált differenciálódott bakteroid mintákból}

\subsubsection{Bevezetés}

Az NCR peptidek aminosav-összetételükből adódóan nagyon változatos szekvenciával, anionos, kationos, vagy semleges töltöttségi állapottal rendelkezhetnek, ezekből a paraméterekből adódóan másképp és más célfehérjékre lehetnek hatással a szimbioszómában. Ezekhez a kísérletekhez a kationos tulajdonságú NCR247 peptidet használtuk. Ez a peptid különlegesen egyedi szekvenciával rendelkezik. Az érett szekvencia (zöld) 24 aminosav hosszúságú, izoelektromos pontja igen magas (pI 10.15). Szignál szekvenciája 23 aminosavból áll.

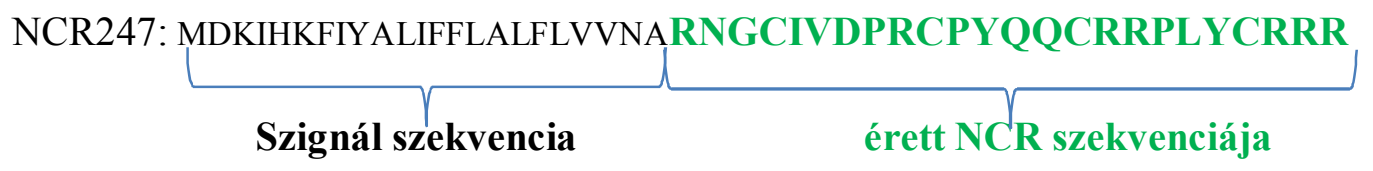

Boman indexe alapján (mely számszerủen fejezi ki a peptid más fehérjékhez való kapcsolódási hajlamát, összegezve a benne található aminosavak hidrofób vagy hidrofil tulajdonságait, [Boman 2003]) az NCR peptidek közül az NCR247 a legelső helyen áll (4.63 kcal/mol), a bizonyítottan antimikrobiális hatású fehérjék Boman indexéhez viszonyítva ez nagyon magas érték, erősen hidrofil karaktert mutat.

Biológiai hatását korábban már több Gram-pozitív és Gram-negatív baktériummal és humán patogén gombafajjal szemben is vizsgálták, s ezekben az in vitro kísérletekben a kémiai úton szintetizált, diszulfid-hidakat nem tartalmazó peptid is antimikrobiális aktivitást mutatott [Van de Velde 2010, Tiricz 2013, Ördögh 2014, Farkas és mtsai, 2014].

Transzkriptom analízis eredménye alapján az NCR247 génje a gümőfejlődés korai fázisában indukálódik. A génexpresszió pontos lokalizálása érdekében GUS reporter génnel fúzionáltattuk az NCR247 promóterét. A transzgénikus gümőben a detektálható GUS-aktivitás megegyezik az NCR247 expressziójával, és azt mutatta, hogy a fehérje a II. zóna idősebb sejtrétegeiben és az interzónában (II-III) lokalizálódik, tehát azokban a zónákban, ahol egyrészt a baktériumok 
osztódása (egymást követő endoreduplikációk) megáll és elkezdődik a sejtalak megnyúlása, valamint ahol a bakteroid sejtek növekedése történik (15. ábra).

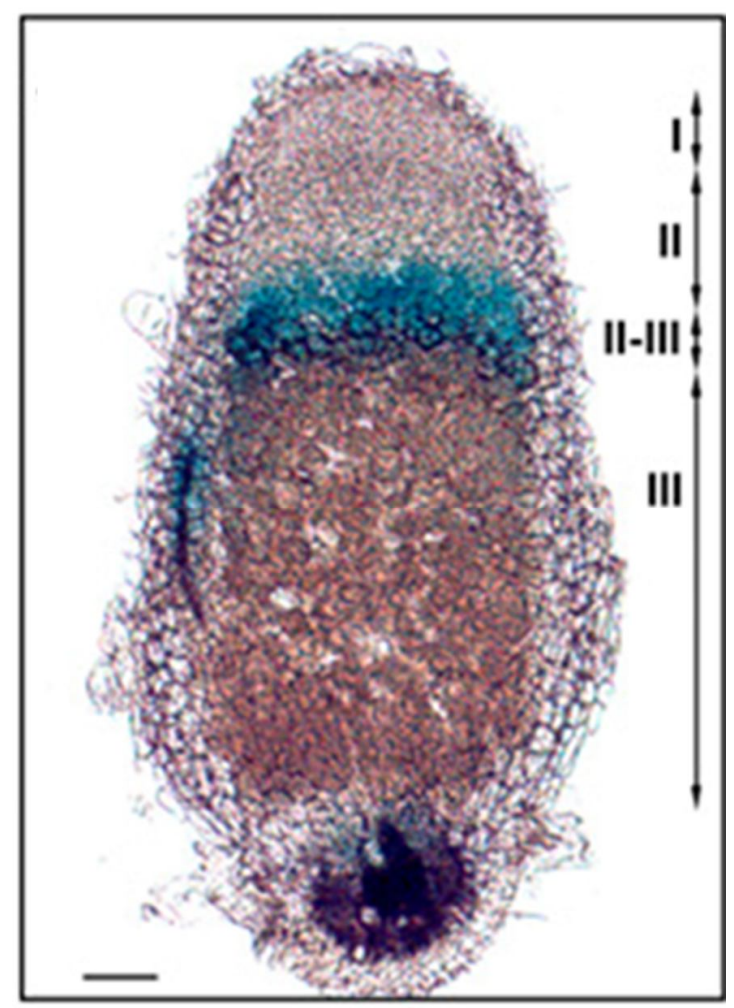

\section{5. ábra: NCR247-GUS}

expresszió a gümőben és FITCNCR247 lokalizációja $S$. meliloti baktérium és bakteroid sejtben.

Kék festéssel jelölve a II zóna öregebb sejtjei és a II-III interzóna sejtjei, ami egybeesik az NCR247-GUS expressziójával transzgénikus M. truncatula gümökben.

Zónák: I, gümő merisztéma; II, infekciós zóna; II-III, interzóna; III, nitrogén fixáció zónája. (Farkas et al. 2014)

Proteomikai kísérleteink során ezt az NCR peptidet nem detektáltuk. Transzkriptom adatok alapján feltételezhető, hogy nagyon kis mennyiségben van jelen a gümő-szüretelés idejére. Ráadásul a teljes triptikus hasítás három kurta peptidet eredményez, tehát egy ilyen komplex elegyben ezek MS/MS analízisre való kiválasztása meglehetősen esetleges.

Proteomikai vizsgálatainkhoz kémiailag szintetizált, diszulfid-hidakat nem tartalmazó peptidet használtunk (akárcsak a biológiai hatás tanulmányozásához), amelyet StrepII- vagy FLAG-taggel láttunk el, hogy a fehérje-komplexeket könnyebben izolálhassuk. S. meliloti (Sm1021) baktérium kultúrát és ezen baktériumok M. truncatula gümőiből izolált differenciált formáit (bakteroid) vizsgáltuk. In vitro kísérleteket végeztünk a megfelelő gyöngyre kötött peptiddel és a baktériumokból vagy bakteroidokból izolált fehérje-elegyekkel. 


\subsubsection{Eredmények}

Kutatásunk célja az volt, hogy meghatározzuk, melyek az NCR247 fehérje baktériumon belüli speciális célmolekulái, célfehérjéi, amelyek lehetővé teszik a peptid számára a bakteriális életfolyamatok befolyásolását. Ahhoz, hogy valóban a vizsgált NCR peptid interakciós partnereit azonosítsuk, a StrepII- és FLAG-szekvenciákkal végzett kontroll-kísérletekre is szükség volt. Ezek eredményei azt mutatták, hogy önmagában a két szekvencia egyike sem köt magához bakteriális fehérjéket jelentős mennyiségben (16. ábra).
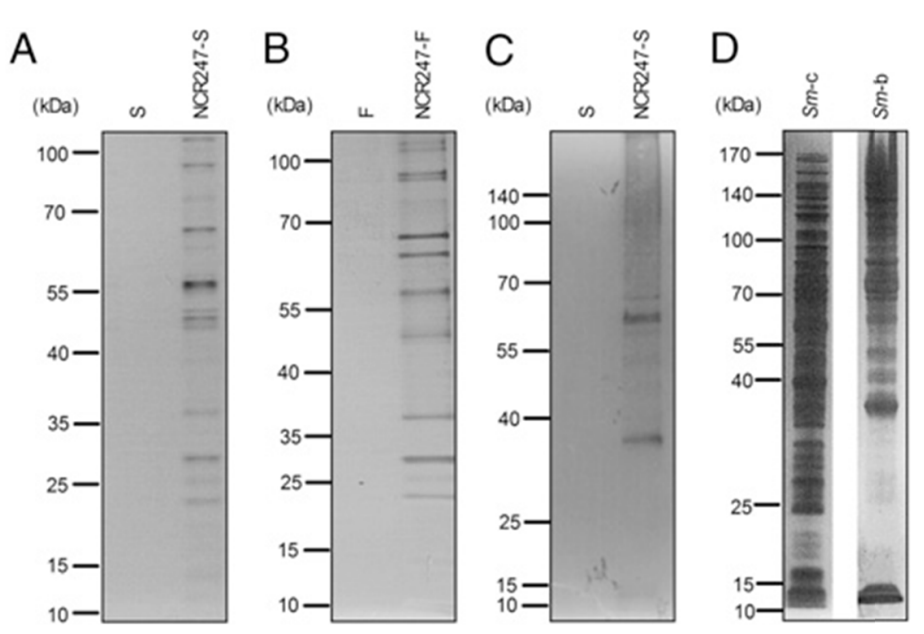

16. ábra. NCR247 kölcsönható fehérjéi $S$. meliloti baktériumban és bakteroidban.

(A) Strep-Tactin oszlopról eluált StrepII (S) és NCR-247-StrepII frakció SDS/PAGE ezüst festéssel megfestve, $S$. meliloti baktérium extraktumból.

(B) Anti-FLAG gyöngyökröl eluált FLAG (F) és NCR247-FLAG (NCR247-FLAG) SDS/PAGE ezüst festéssel, $S$. meliloti baktérium extraktumból.

(C) Strep-Tactin oszlopról eluált StrepII (S) és NCR-247-StrepII frakció SDS/PAGE ezüst festéssel megfestve, $S$. meliloti bakteroid extraktumból.

(D) Ezüst-festett SDS/PAGE S. meliloti baktérium (Sm-c) és bacteroid (Sm-b) extraktumokból. (Farkas et al. 2014)

A bakteroid minta SDS/PAGE gél képén jól látszik, hogy a bakteriális differenciálódással a bakteriális fehérjék mennyisége lecsökkent, így a lehetséges interakciós partnerek száma is redukálódott (16. ábra (D)).

A baktérium minták esetén gélből kivágott fehérjesávokat analizáltunk, míg bakteroid mintánál az affinitás-oszlopról eluálódott frakció további frakcionálása nélkül, azaz oldatban emésztés után végeztünk LC-MS/MS analízist. A StrepII-NCR247 peptiddel végzett kísérletben azokat a fehérjéket tekintettük kölcsönható partnereknek, melyek legalább 3 szignifikáns peptidtalálatot eredményeztek (kivéve azonosított NCR peptidek esetén, ahol egy azonosított és manuálisan ellenörzött szekvenciával már elfogadtuk a fehérjetalálatot). 
Összesítve a baktérium-kultúrákból származó eredményeket azt kaptuk, hogy a lehetséges interakciós partnerek közül az azonosítások nagy hányadát a riboszómális fehérjék teszik ki: 14 kis alegységet (S1, S2, S3, S4, S5, S6, S7, S8, S9, S11, S12, S13, S16, S18) és 12 nagy (L1, L2, L3, L4, L5, L6, L9, L10, L13, L16, L19, L23) alegységet azonosítottunk (teljes azonosított fehérjelista megtalálható a Függelék 15. táblázatában). A riboszómális fehérjék mellett a GroEL bakteriális chaperon volt nagy mennyiségben jelen a mintákban, ezen kívül piruvát dehidrogenázkomplex, transzaldoláz, RNS-polimeráz béta és béta’ alegységei, elongációs faktorok és egyéb fehérjék is jelen voltak a mintában.

A bakteroidokban a GroEL és piruvát dehidrogenáz-komplex, kisebb mennyiségben riboszómális fehérjék voltak azonosíthatóak (Függelék 16. táblázat). A GroEL jelenlétét az NCR247-tel kölcsönható komplexben Western blot analízissel is bizonyítottuk. Bakteroid mintákban új specifikus interakciós partnerként a nitrogenáz komplex elemeit, valamint további NCR peptideket is azonosítottunk (NCR028, NCR169, NCR290). A baktérium és bakteroid mintákból származó lehetséges kölcsönható fehérjéket funkcionális csoportokba soroltuk annak érdekében, hogy jobban áttekinthetővé váljanak a két preparátum közötti különbségek (17. és 18. ábra). A csoportba sorolás egyszerü klasszifikációval, az NCBI adatbázisban fellelhető, adott fehérjéhez tartozó validált vagy prediktív funkciós csoportba rendezés alapján történt. 


\section{Funkcionális csoportok, baktérium minták}

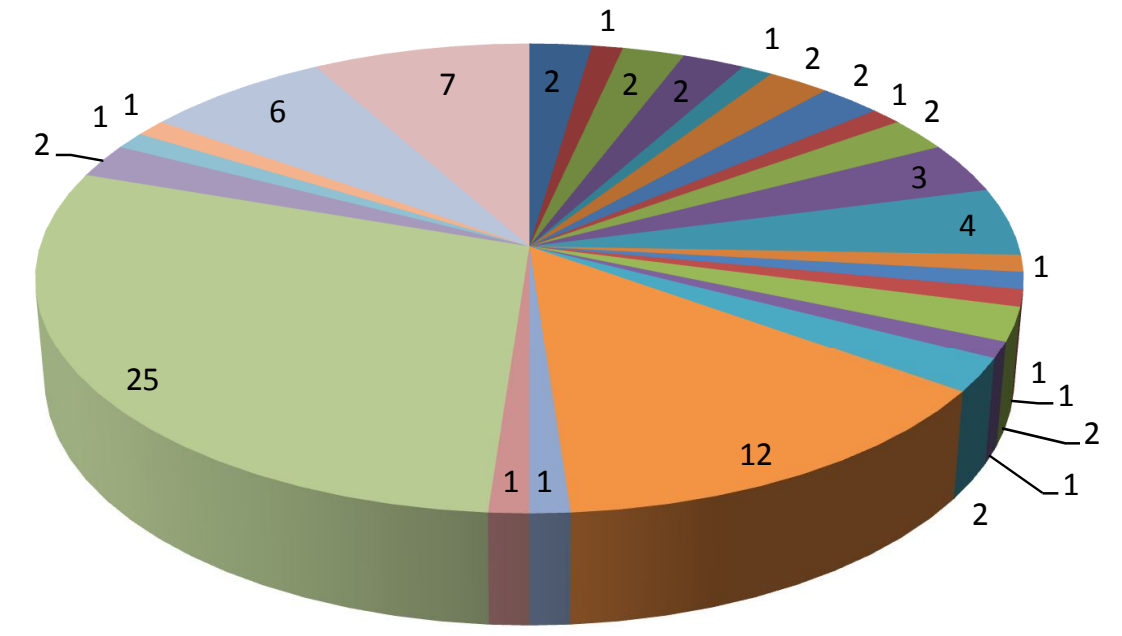

- aminosav bioszintézis

- aminosav szintézis

- acetiltranszferázok

- ATP szintézis

chaperonok

च citoplazma fehérjék

- DNS-kötő fehérjék

- fibrillum fehérjék

glükolízis, szénhidrát bontás

uhelikázok

- hipotetikus fehérjék

- lipid bioszintézis

- lipid metabolizmus

- lipoproteinek

membránfehérjék

- fémion-kötés

nukleázok

nukleotid kötés

noxidoreduktázok

घproteázok

riboszómális fehérjék

RNS polimerázok

RNS szintetázok

stresszválasz-fehérjék

transzferázok

transzportfehérjék

17. ábra: StrepII-NCR247 és FLAG-NCR247 kísérletek során lehetséges interakciós partnerekként azonosított bakteriális fehérjék funkcionális csoportosítása 


\section{Funkcionális csoportok, bakteroid minta}

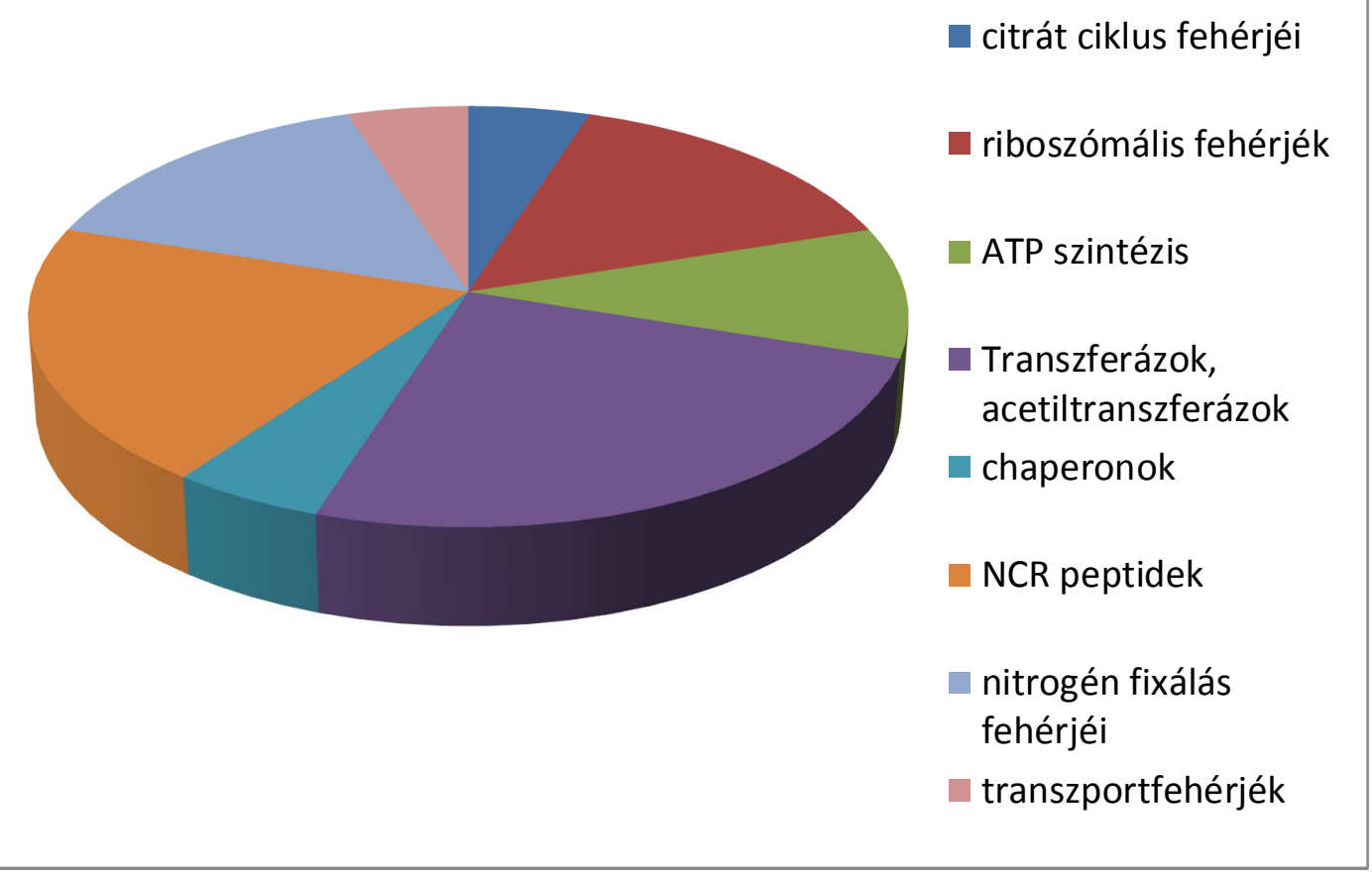

18. ábra: StrepII-NCR247 kísérlet során lehetséges interakciós partnerként azonosított bateriális és növényi fehérjék funkcionális csoportosítása.

\subsubsection{Diszkusszió}

Előző tanumányaink (4.1.-4.3.) már bizonyították, hogy az NCR peptidek jelen vannak, méghozzá nagy számban és jelentős mennyiségben a szimbionta bakteroidokban. Egyedi biológiai hatásuk (az NCR169 kivételével) azonban mindmáig nem ismert. Természetes körülmények között a peptidek nem ölik meg a növénnyel szimbiózisba lépő baktériumokat, hanem a bakteroiddá differenciálódás esszenciális irányítói. Feltehető hogy eme tevékenységüket a baktérium-fehérjékkel kölcsönhatásban érik el. Az előző fejezetben (4.3.) már demonstráltuk, hogy egy NCR peptid hiánya drámaian átalakíthatja a bakteroid fehérje-készletét. Ebben a kísérletben egy NCR peptid kötőpartnereit azonosítottuk.

Miután a szabadon élő baktériumokból és önállóan életképtelen bakteroidokból is azonosítottuk az NCR247 lehetséges kölcsönható partnereit, remélhető, hogy a különbségek rávilágítanak e peptid különböző funkcióira a differenciálódás folyamatában. A baktériumokkal végzett 
kísérletekben a fehérjéket gélsávonként azonosítottuk, gyakran primitív, kevéssé érzékeny készülékekkel. A bakteroidokkal végzett kísérletet csupán új, "state-of-the-art" tömegspektrométerünk tette lehetővé.

A fehérjekomplexek legnagyobb mennyiségben előforduló alkotói a riboszómális fehérjék és a GroEL voltak. A riboszómális fehérjékröl korábbi vizsgálatok alapján feltételezhető volt, hogy nagy abundanciájuk és ragadós természetük miatt "szennyező anyagként" lehetnek benne a mintákban, emiatt az eredményeinket eleinte kétkedéssel fogadtuk. A további vizsgálatok alapján meggyőződtünk arról, hogy az NCR247 valóban kötődik a riboszómákhoz és negatívan befolyásolja a bakteriális transzlációs folyamatokat [Farkas et al. 2014]. A GroEL chaperon egy igen nagy mennyiségben előforduló bakteriális fehérje, mely elözetes irodalmi adatok alapján fehérjék százaival lehet kölcsönhatásban [Kirkpatrick 2011]. Emiatt elöször azt feltételeztük, hogy az NCR247-GroEL kölcsönhatás nem bír biológiai relevanciával. Az ezt a feltételezést cáfolni vagy bizonyítani hivatott immuno-precipitációs kísérletek egyértelmüen demonstrálták, hogy az NCR247 kötődik a GroEL fehérjéhez, a két fehérje komplexet képez. Biológiailag rögtön fontosnak tünik, hogy az NCR247 kölcsönhatásba lép a nitrogén-fixálásban szerepet játszó fehérjékkel és más NCR peptidekkel. Nem tudhatjuk, hogy ezek direkt vagy közvetett kölcsönhatást jelentenek. Nem tisztáztuk ezeknek a kötődéseknek a szerepét. Összegezve, kísérleteinkben azonosítottunk valós és érdekesnek tünő kölcsönható partnereket, de természetesen nem valamennyit. Például, előzetes kutatási eredmények alapján, egy célzott kísérlettel együttmúködő partnereink bebizonyították, hogy az NCR247 peptid, bejutva a sejtmembránon az FtsZ monomerekkel komplexet képez, gátolja azok polimerizációját [Farkas et al. 2014]. Ez a prokarióta sejtosztódásban fontos fehérje az, amely baktériumokban elsőként jelenik meg a két keletkezö sejt között, és hozza létre a válaszfalakat (septumokat). Ha az NCR247 interakcióba lépve az FtsZ fehérjével beavatkozik ennél a lépésnél, akkor a septumok kialakulása elmarad, a sejt viszont osztódik, így alakulhat ki a poliploid bakteroid sejt. Elképzelhető, hogy ezt a fehérjét azért nem azonosítottuk, mert az izoláláshoz használt "csalétek" nem volt megfelelő konformációjú, vagy a diszulfid-hidak hiánya miatt, vagy az izolálást megkönnyítő toldalék-szekvencia interferálása miatt. Az is lehetséges, hogy az affinitás a fehérjék között nem eléggé erős az izoláláshoz, mert az FtsZ fehérjét azonosítottuk a 4.2 és 4.3 kísérletek során is. 
Napjainkban, amikor a kutatások egyik központi témája az antibiotikum-rezisztencia kérdése az NCR247 bizonyítottan antimikrobiális hatásánál fogva jó célpontja lehet az alkalmazott biológiai, orvosi célú további vizsgálatoknak. Ehhez azonban szükség van a natív fehérje konformációjának, azaz a diszulfid hidak rendeződésének megismerésére, hisz pontos biológiai hatás, a fehérje sejten belüli célmolekulái csak a biológiailag aktív konformációjú fehérjével végzett kísérlettel azonosíthatóak. Ehhez természetesen jó alapot adnak a fentebb ismertetett, diszulfid-hidakat nem tartalmazó, szintetikus NCR247 peptiddel végzett kutatások. A csak négy ciszteint tartalmazó NCR-ek esetén sem egyszerü rutinfeladat a diszulfid-hidak feltérképezése, az erre irányuló kísérleteink már folyamatban vannak. Célunk az ismertetett kísérletek ismételt elvégzése a természetben előforduló konformációjú NCR247 peptiddel.

$\mathrm{Az}$ analízisek módszertana (3.fejezet) híven tükrözi azt a fejlödést, amin a proteomikai laboratórium müszerparkja és a használt szoftverek keresztülmentek 4 év alatt, ezen különbségek ellenére az eredmények összevethetőek és összegezhetőek. Ahhoz, hogy messzebbre menő következtetéseket vonjunk le a különbségekböl, célszerü lesz majd a kísérleteket megismételni a jelenlegi tömegspektrométerrel, illetve célzott biológiai kísérletekkel kell majd megpróbálnunk a hatás-mechanizmusok kiderítését. 


\section{Köszönetnyilvánítás}

Köszönettel tartozom témavezetőmnek, Dr. Medzihradszky F. Katalinnak, hogy a Proteomikai Kutatócsoportban dolgozhattam, és köszönöm a sok segítséget, tanácsot, kritikát és beszélgetést, amit az évek során kaptam Töle. Köszönöm a csoport minden tagjának, hogy befogadtak, köszönöm Dr. Darula Zuzsannának, Dr. Hunyadi-Gulyás Évának és Dr. Klement Évának, hogy betanítottak, türelemmel foglalkoztak velem, segítették és irányították doktori munkámat.

Köszönettel tartozom Dr. Kondorosi Évának is az általa nyújtott segítségért, iránymutatásért, és külön köszönöm Neki fiatal kutatói ösztöndíjam felajánlását.

Köszönöm Magyaródi Erzsébet a kezdeti gyakorlati munka során nyújtott pótolhatatlan segítségét.

Végül, nagyon köszönöm, hogy családom és barátaim mindenben mellettem álltak, leginkább pedig köszönöm Leonnak, hogy szeret, és hogy elviselt egy sokszor ideges, doktori dolgozatot író anyát. 
6. Irodalomjegyzék

Altschul, S. F., Gish, W., Miller, W., Myers, E. W., Lipman, D. J. Basic local alignment search tool. J Mol Biol 1990, 215, 403-410.

Alunni, B., Kevei, Z., Redondo-Nieto, M., Kondorosi, A., et al. Genomic organization and evolutionary insights on GRP and NCR genes, two large nodule-specific gene families in Medicago truncatula. Mol Plant Microbe Interact 2007, 20, 1138-1148.

Andreev, V. P., Petyuk, V. A., Brewer, H. M., Karpievitch, Y. V., et al. Label-free quantitative LC-MS proteomics of Alzheimer's disease and normally aged human brains. J Proteome Res 2012, 11, 3053-3067.

Bestel-Corre, G., Dumas-Gaudot, E., Poinsot, V., Dieu, M., et al. Proteome analysis and identification of symbiosis-related proteins from Medicago truncatula Gaertn. by twodimensional electrophoresis and mass spectrometry. Electrophoresis 2002, 23, 122-137.

Biemann, K. Nomenclature for peptide fragment ions (positive ions). Methods Enzymol 1990, 193, 886-887.

Boman HG. Antibacterial peptides: basic facts and emerging concepts. J Intern Med. 2003, 254, 197-215. Review.

Bonaldi, K., Gargani, D., Prin, Y., Fardoux, J., et al. Nodulation of Aeschynomene afraspera and A. indica by photosynthetic Bradyrhizobium Sp. strain ORS285: the nod-dependent versus the nod-independent symbiotic interaction. Mol Plant Microbe Interact 2011, 24, 1359-1371.

Boyd, E. S., Peters, J. W. New insights into the evolutionary history of biological nitrogen fixation. Frontiers in Microbiology 2013, 4, 201 doi: 10.3389/fmicb.2013.00201

Doherty, M. K., Whitehead, C., McCormack, H., Gaskell, S. J., Beynon, R. J. Proteome dynamics in complex organisms: using stable isotopes to monitor individual protein turnover rates.

Proteomics 2005, 5, 522-533.

Dunkley, P., R., Jarvie, P., E., Robinson, P, J. A rapid Percoll gradient procedure for preparation of synaptosomes. Nat Protoc 2008, 3, 1718-1728. 
Falkowski, P. G. Evolution of the nitrogen cycle and its influ- ence on the biological sequestration of CO2 in the ocean. Nature 1997, 387, 272-275.

Farkas, A., Maróti, G., Dürgő, H., Györgypál, Z., et al. The Medicago truncatula symbiotic peptide NCR27 contributes to bacteroid differentiation through multiple mechanisms. Proc Natl Acad Sci U S A 2014, 111, 5183-5188.

Fedorova, M., van de Mortel, J., Matsumoto, P. A., Cho, et al. Genome-wide identification of nodule-specific transcripts in the model legume Medicago truncatula. Plant Physiol. 2002, 130 (2), 519-37.

Galibert F., Finan T. M., Long S. R., Puhler A. et al. The composite genome of the legume symbiont Sinorhizobium meliloti. Science. 2001, 293(5530):668-72 transzkriptom

Garcia, J., Barker, D. G., and Journet, E. P. Seed storage and germination. Medicago Hand Book 2006.

Gibson, K. E.; Kobayashi, H.; Walker, G. C. Molecular determinants of a symbiotic chronic infection. Annu Rev Genet. 2008, 42, 413-41.

Goldberg, I., Nadler, V., Hochman, A. Mechanism of nitrogenase switch-off by oxygen. $J$. Bacteriol 1987, 169, 874-879.

Griffin, T. J., Gygi, S. P., Ideker, T., Rist, B. et al Complementary Profiling of Gene Expression at the Transcriptome and Proteome Levels in Saccharomyces cerevisiae. Cell Mol Proteomics 2002, 1, 323-333.

Gruber, C. W., Elliott A. G., Ireland D. C., Delprete P. G., et al. Distribution and evolution of circular miniproteins in flowering plants. Plant Cell 2008, 20, 2471-2483.

Gualtieri, G., Bisseling, T. The evolution of nodulation. Plant Mol Biol, 2000, 42, 181-194.

Guan, S., Price J. C., Prusiner S. B., Ghaemmaghami S., Burlingame A. L., A data processing pipeline for mammalian proteome dynamics studies using stable isotope metabolic labeling. $\mathrm{Mol}$ Cell Proteomics 2011, 10, M111.010728. 
Gygi, S. P., Rist, B., Gerber, S. A., Turecek, F., et al. Quantitative analysis of complex protein mixtures using isotope-coded affinity tags. Nat Biotechnol 1999, 17, 994-999.

Haag, A.F., Baloban, M., Sani, M., Kerscher, B., et al. Protection of Sinorhizobium against host cysteine-rich antimicrobial peptides is critical for symbiosis. PLoS Biol 2011, 9, e1001169. doi: 10.1371/journal.pbio.1001169.

Hiller, K., Grote, A., Scheer, M., Münch, R., Jahn, D. PrediSi: prediction of signal peptides and their cleavage positions. Nucleic Acids Res 2004, 32, W375-379.

Hirsch, A. M. Developmental biology of legume nodulation. New Phytologist 1992, 122, 211 237.

Hoffmann, E. de, Stroobant, V. Mass spectrometry Principles and Applications 3rd edition, Wiley, Chichester, UK, 2007.

Jonscher, K. R., Yates, J. R. 3rd The quadrupole ion trap mass spectrometer--a small solution to a big challenge. Anal Biochem 1997, 244, 1-15.

Kereszt, A., Mergaert, P., Kondorosi, E. Bacteroid Development in Legume Nodules: Evolution of Mutual Benefit or of Sacrificial Victims? Mol Plant Microbe Interact 2011, 24, 1300-1309.

Kevei, Z., Vinardell, J. M., Kiss, G. B., Kondorosi, A. és Kondorosi, E. Glycine-rich proteins encoded by a nodule-specific gene family are implicated in different stages of symbiotic nodule development in Medicago spp. Mol Plant Microbe Interact, 2002, 15, 922-931.

Kirkpatrick, C. L., Viollier, P. H. New(s) to the (Z-)ring. Curr Opin Microbiol 2011, 14, 691697.

Kondorosi, E., Mergaert, P., Kereszt, A., A paradigm for endosymbiotic life: cell differentiation of Rhizobium bacteria provoked by host plant factors. Annu Rev Microbiol 2013, 67, 611-628.

Larrainzar, E., Wienkoop, S., Weckwerth, W., Ladrera, R., et al. Medicago truncatula root nodule proteome analysis reveals differential plant and bacteroid responses to drought stress. Plant Physiol 2007, 144, 1495-1507. 
Lewandowska, D., ten Have, S., Hodge, K., Tillemans, V., et al. Plant SILAC: stable-isotope labelling with amino acids of arabidopsis seedlings for quantitative proteomics. PLoS One 2013, 8, e72207. doi: 10.1371/journal.pone.0072207.

Maunoury, N., Redondo-Nieto M., Bourcy, M., Van de Velde, W. et al. Differentiation of symbiotic cells and endosymbionts in Medicago truncatula nodulation are coupled to two transcriptome-switches. PLoS One 2010, 5 (3), e9519.

McRae, D. G., Miller, R. W., Bernet, W. B. Viability of alfalfa nodule bacteroids isolated by density gradient centrifugation. Symbiosis 1989, 7, 67-80.

Medzihradszky, K. F., Chalkley, R. J. Lessons in de novo peptide sequencing by tandem mass spectrometry. Mass Spectrometry Reviews 2015, 34, 43-63.

Mergaert P., Mikovics, K., Kelemen, Z., Maunoury, N. et al. A novel family in Medicago truncatula consisting of more than 300 nodule-specific genes coding for small, secreted polypeptides with conserved cysteine motifs. Plant Physiol 2003, 132, 161-173.

Mergaert, P., Uchiumi, T., Alunni, B., Evanno, G., et al. Eukaryotic control on bacterial cell cycle and differentiation in the Rhizobium-legume symbiosis. Proc Natl Acad Sci U S A 2006, 103, 5230-5235.

Mierziak, J., Kostyn, K., Kulma, A. Flavonoids as important molecules of plant interactions with the environment. Molecules 2014, 19, 16240-162465.

Nallu, S., Silverstein, K. A., Samac, D. A. Bucciarelli, B., et al. Regulatory patterns of a large family of defensin-like genes expressed in nodules of Medicago truncatula. PLoS One 2013, 8, e60355.

Old, W. M., Meyer-Arendt, K., Aveline-Wolf, L., Pierce, K. G., et al. Comparison of label-free methods for quantifying human proteins by shotgun proteomics. Mol Cell Proteomics 2005, 4, 1487-1502.

Oldroyd, G. E., Downie, J. A. Coordinating nodule morphogenesis with rhizobial infection in legumes. Annu Rev Plant Biol, 2008, 59, 519-546. 
Ong, S. E., Blagoev, B., Kratchmarova, I., Kristensen, D. B., et al. Stable isotope labeling by amino acids in cell culture, SILAC, as a simple and accurate approach to expression proteomics. Mol Cell Proteomics 2002, 1, 376-386.

Op den Camp, R., Streng, A., De Mita, S., Cao, Q., Polone, E. et al. LysM-type mycorrhizal receptor recruited for rhizobium symbiosis in nonlegume Parasponia. Science. 2011, 18;331(6019):909-12.

Ördögh, L., Vörös, A., Nagy, I., Kondorosi, É., Kereszt, A. Symbiotic Plant Peptides Eliminate Candida albicans Both In Vitro and in an Epithelial Infection Model and Inhibit the Proliferation of Immortalized Human Cells. Biomed Res Int 2014, 320796 doi: 10.1155/2014/320796

Perret, X., Staehelin, C. és Broughton, W. J. Molecular basis of symbiotic promiscuity. Microbiol Mol Biol Rev 2000, 64, 180-201.

Petersen, T. N., Brunak, S., von Heijne, G., Nielsen, H. SignalP 4.0: discriminating signal peptides from transmembrane regions. Nature Methods 2011, 8, 785-786.

Popp, C., Ott, T. Regulation of signal transduction and bacterial infection during root nodule symbiosis. Curr Opin Plant Biol 2011, 14, 458-467.

Pratt J. M., Petty, J., Riba-Garcia, I., Robertson, D. H. et al. Dynamics of protein turnover, a missing dimension in proteomics. Mol Cell Proteomics. 2002, 1, 579-591.

Rose, C. M., Venkateshwaran, M., Volkenin, J. D., Grimsrud, P. A., et al. Rapid phosphoproteomic and transcriptomic changes in the rhizobia-legume symbiosis. Mol Cell Proteomics 2012, 11, 724-744.

Ross, P. L., Huang, Y. N., Marchese, J. N., Williamson, B., et al. Multiplexed protein quantitation in Saccharomyces cerevisiae using amine-reactive isobaric tagging reagents. $\mathrm{Mol}$ Cell Proteomics 2004, 3, 1154-1169.

Roux, B., Rodde, N., Jardinaud, M. F., Timmers, et al. An integrated analysis of plant and bacterial gene expression in symbiotic root nodules using laser-capture microdissection coupled to RNA sequencing. Plant J. 2014, 77 (6), 817-37. 
Sandal, N., Krusell, L., Radutoiu, S., Olbryt, M., Pedrosa, A., Stracke, S. et al. (). A genetic linkage map of the model legume Lotus japonicus and strategies for fast mapping of new loci. Genetics 2002, 161(4):1673-83.

Sinharoy, S., Torres-Jerez, I., Bandyopadhyay, K., Kereszt A., et al. The C2H2 transcription factor regulator of symbiosome differentiation represses transcription of the secretory pathway gene VAMP721 a and promotes symbiosome development in Medicago truncatula. Plant Cell 2013, 25, 3584-601.

Terpolilli, J. J., Hood, G. A., Pool, P. S. What determines the efficiency of N(2)-fixing rhizobium-legume symbioses? Adv Microb Physiol 2012, 60, 325-389.

Tiricz, H., Szucs, A., Farkas, A, Pap, B. et al. Antimicrobial nodule-specific cysteine-rich peptides induce membrane depolarization-associated changes in the transcriptome of Sinorhizobium meliloti. Appl Environ Microbiol 2013, 79, 6737-6746.

Van de Velde, W., Zerihov, G., Szatmari, A., Debreczeny, M. et al. Plant peptides govern terminal differentiation of bacteria in symbiosis. Science 2010, 327, 1122-1126.

Vasse, J., de Billy, F., Camut, S. és Truchet, G. Correlation between ultrastructural differentiation of bacteroids and nitrogen fixation in alfalfa nodules. J Bacteriol,1990, 172, 4295-4306.

Volkening, J. D., Bailey, D. J., Rose, C. M., Grimsrud, P. A. et al. A proteogenomic survey of the Medicago truncatula genome. Mol Cell Proteomics 2012, 11, 933-944.

Wang, D., Griffitts, J., Starker, C., Fedorova, E. et al. A Nodule-specific protein secretory pathway required for nitrogen-fixing symbiosis. Science 2010, 327, 1126-29.

Zhang, K., McKinlay, C., Hocart, C. H., Djordjevic, M. A. The Medicago truncatula small protein proteome and peptidome. J Prot Res 2006, 5, 3355-3367.

Colebatch G., Desbrosses G., Ott T., Krusell L. et al. Global changes in transcription orchestrate metabolic differentiation during symbiotic nitrogen fixation in Lotus japonicus. Plant J. 2004, 39: $487-512$. 
Benedito V.A., et al. A gene expression atlas of the model legume Medicago truncatula. Plant J. 2008, 55: 504-513. 


\section{7. Összefoglalás}

Doktori munkámat a Szegedi Biológiai Kutatóközpont Proteomikai Kutatócsoportjában már a kezdetektől a szimbiotikus gyökérgümőkkel foglalkozó témán dolgozva végeztem. A pillangós virágú növények és endoszimbionta baktériumpartnereik kapcsolata, a nitrogénkötés kialakulásának és müködésének vizsgálata nagy jelentőséget kapott az utóbbi évtizedekben, eredményeink orvosi és környezetvédelmi vonatkozások miatt is fontosak lehetnek a jövőben.

Munkánk során a nitrogénkötő szimbiózisban szerepet játszó legfontosabb növényi fehérjék csoportjára, az NCR peptidekre fókuszáltunk. Ezek a vegyületek vezérlik és szabályozzák a szimbiotikus baktériumok bakteroidokká differenciálódását. Míg mRNS-szinten már rengeteg információ állt rendelkezésre ezekről a géntermékekről, fehérje-formájában még senki sem azonosította őket. Számos kísérlet bizonyította viszont, hogy a kimutatható transzkripciós aktivitás nem mutat egyértelmü korrelációt a fehérjeszinten megjelenő "termékkel”. Kérdéses volt, hogy mindezen géntermékek (körülbelül 560 NCR-t kódoló génről tudunk $M$. truncatulában) egyáltalán megjelennek-e a bakteroidokban, $\mathrm{s}$ ha megjelennek, mikor teszik azt, mennyi lehet az NCR fehérjék féléletideje, s egymásra milyen hatást gyakorolhatnak stb. Feladatunk tehát legelőször az NCR peptidek fehérjeszintü azonosítása volt. Kísérleteinket Sinorhizobium medicae (WSM419) és S. meliloti (Sm1021) baktériumokkal fertőzött Medicago truncatula A17 Jemalong növény indeterminált gümöivel végeztük. A vad típusú növény gyökérgümőinek vizsgálata mellett $M$. truncatula $6 \mathrm{~V}$ mutáns gümőinek növényi és bakteriális eredetű fehérjéit is analizáltuk.

Céljaink az alábbiak voltak:

1) Vizsgálódásunk elsődleges célja az volt, hogy a baktériumok transzformálására és irányítására szolgáló növényi-eredetű NCR peptidek jelenlétét kimutassuk a bakteroidokban. Célunk volt továbbá a detektált szekvenciák alapján a szignál-peptidáz hasítóhelyének igazolása.

2) Arról is igyekeztünk információt szerezni, hogy mi lehet a biológiai szerepe ezeknek a polipeptideknek. Ehhez ki akartuk deríteni, hogy:

a) van-e különbség a különböző fejlődési stádiumban levő bakteroidok NCR- tartalmában, 
b) mi a különbség a vad típusú és egy adott fenotípussal rendelkező mutáns növény gümőinek NCR és bakteriális fehérje tartalmában,

c) mely bakteriális és növény fehérjék hatnak kölcsön egy bizonyítottan antimikrobiális hatású NCR peptiddel.

Természetesen a fenti célok eléréséhez ki kellett dolgoznunk a megfelelő minta előkészítő eljárásokat. A gümő szöveti szerkezetéből adódóan meg kellett találni a megfelelő módszert a növényi és a bakteriális eredetű sejtek elkülönítésére, majd a bakteroidok anyagának feltárására. Kísérletekkel teszteltük ezen kívül a baktérium-mintákra általánosan használt ultrahangos sejtfeltárási módszert is. A feltárás utáni komplex fehérje-elegyet különféle módszerekkel, szelektív dúsításokkal igyekeztünk egyszerüsíteni, hogy az NCR fehérjék detektálása minél sikeresebb legyen. A dúsításra az NCR-ek speciális tulajdonságait úgy, mint a relatíve kis méretüket és viszonylag magas cisztein-tartalmukat igyekeztünk kihasználni. A minta-előkészítés lépéseit elöször egy bakteroid elegyen fejlesztettük ki. Mivel a későbbiekben a vad-típusú növények mellett bizonyos mutánsok gyökérgümöiben is kutakodni szándékoztunk, és össze is kívántuk hasonlítani a kapott eredményeket, ezért az analízis teljes folyamatát ehhez a célhoz igazítottuk.

Az NCR peptidek jelenlétét vizsgáltuk intakt (nem tisztított) gümőkben, és olyan bakteroidtisztítási eljárásokat alkalmazva, melyek a bakteroid differenciálódás különböző fokain lévő bakteroidokat és teljesen átalakult szimbiontákat eredményeztek.

A vad és mutáns genotípus összehasonlításakor használt 6V mutánsra jellemző, hogy a gyökerén létrejönnek ugyan a gümők, de azok érése egy ponton megáll. A bakteroidok differenciálódása így nem lesz megfelelö, ezért légköri nitrogénkötésre képtelenek.

Munkámat részben Kondorosi Éva irányításával végeztem. A Kondorosi-csoport egy ideje foglalkozik az NCR247 peptid biológiai hatásával, többféle megközelítéssel bizonyították antimikobiális hatását A peptid lehetséges kölcsönható partnereit ezen vizsgálatok eredményeiből kiindulva, azok alátámasztására, az antimikrobiális hatás hátterének bizonyítására kutattuk. 
Eredmények

Az NCR peptidek fehérjeszintü azonosítását intakt gümökből és bakteroidokból nyert frakcionálatlan fehérje-elegyből végeztük. A triptikus emésztést automatizált LC-MS/MS analízis követte, majd az adatok kiértékelése a Uniprot, egy „házi NCR-adatbázis” és a Protein Prospector szoftver segítségével. Az intakt gümö analízisének eredményei azt mutatták, hogy bár az abundáns NCR peptidek detektálhatóak ilyen komplex elegyben is, a baketeroidok izolálására mindenképp szükség van. A további tisztítást két egymást követő folyamatban végeztük, az első, „rövid” tisztítási folyamat eredményeként a gümőben megtalálható, a baktérium-bakteroid átalakulás összes fázisában lévő szimbiontákat kinyerhetjük. Az ezt követő Percoll-grádiensen történő centrifugálással a már teljesen differenciálódott bakteroidok frakciója különíthető el. Az intakt gümőből két, a preparációk utáni bakteroid-mintákból 3-3 biológiai ismétlést vizsgáltunk, hogy meggyözödjünk arról, hogy eredményeink reprodukálhatóak. Az intakt gümő mintákból a technikai ismétlésekkel összesen $\sim 300$ fehérjét tudtunk azonosítani, ezeknek több mint a fele növényi eredetü volt, közöttük 45 NCR peptid. A rövid tisztítási eljárás után kapott mintákból, a három független biológiai mintát együttvéve, az azonosított fehérjék száma megközelítette a 600at, ennek 2/3-a bakteriális fehérje volt, a növényi fehérjék közül 118 volt NCR peptid.

Az érett, nitrogén-fixáló bakteroidból, a három egymástól független minta eredményeit együtt kezelve 313 bakteriális fehérjét és 103 növényi eredetü fehérjét azonosítottunk, ebböl már 75 volt NCR.

A kísérletsorozatban összesen 138 NCR peptidet találtunk. Miután az automatikus adatgyüjtés során a prekurzor ion kiválasztása némiképp esetleges, ezért a két tisztítási eljárásból származó NCR-készlet összevetésekor az MS- és retenciós idő-alapú adat-összehasonlítást választottuk. Az MS-adatokat a fitXIC program segítségével vetettük ezzel össze. Egy NCR peptidet abban az esetben tekintettünk a preparálási eljárás szempontjából egyedinek, ha legalább egy triptikus peptidje minimum két ismétlésben detektálható volt, és a másik preparálási eljárás LC-MS kísérleteiben egyszer sem volt detektálva. Ezen kritériumok alapján találtunk különbségeket. 12 NCR peptidet csak a bakteroid-keverék tartalmazott, így elképzelhető, hogy ezek a molekulák a gümőfejlődés korai szakaszában is szükségesek. Öt NCR peptid csupán az érett bakteroid elegyben volt kimutatható, ez talán azt jelenti, hogy későbbi vagy hosszabban tartó szerepük van a szimbiózis folyamatában. Az azonosított NCR-ek jelentős részénél sikerült az érett peptid N- 
terminális szekvenciáját detektálnunk, így ezeknél bizonyítást nyert a szignál-peptidáz valós hasítási helye.

Következő vizsgálatunkban S. medicae WSM419 baktériummal fertőzött $M$. truncatula vad típusú és $6 \mathrm{~V}$ mutánsa gümőinek fehérjekészletét hasonlítottuk össze. A $6 \mathrm{~V}$ mutánst az teszi érdekessé, hogy az NCR169 gén hiányában légköri nitrogén kötésére képtelenné válik. Ezzel a munkával egy konkrét NCR peptid hatásáról szereztünk fehérje-szintü bizonyítékokat. Bakteroid-keverékekkel dolgoztunk, genotípusonként három párhuzamos mintával, mindegyikből három technikai ismétléssel, oldatban emésztve, a második biológiai mintából SDS-PAGE fehérje-frakcionálás és gélben emésztés is történt. Az oldat-mintákból 120 perces, a gél mintából sávonként 60 perces LC-MS analízist végeztünk, az eredményeket „egybefüzve” értelmeztük. A kvantitatív értékelést a spektrumszámlálás módszerével végeztük. A két minta fehérjetartalmának összehasonlításakor minimum $50 \%$ változást tekintettünk figyelemre méltónak. Tizenhat olyan fehérjét azonosítottunk a mintákban, amelyek határozottan nagyobb mennyiségben voltak jelen a mutáns növényekről gyüjtött gümőkben. Ezek között pillanatnyilag szisztematikus összefüggést nem tudunk kimutatni. Némiképp több, 23 fehérje “tünt el” vagy mutatott jelentős csökkenést a mutáns gümőkben. Növényi fehérjék közül érdekes módon hisztonokat detektáltunk feldúsulva a mutánsokban, míg a vad-típusú növényben jelentősen nagyobb mennyiségben jelenlevő fehérjék egytől egyig a szimbiózissal összefüggő géntermékek, NCR vagy GRP peptidek voltak. Eredményeink fehérje-szinten igazolják, hogy a $6 \mathrm{~V}$ mutáns bakteroidjaiban a nitrogén-fixálás nem működik megfelelően: a nitrogén-kötéssel kapcsolatos fehérjéket (NifT/FixU family protein, Ferredoxin III 4(4Fe-4S) nif-specific, Nitrogenase protein, Nitrogen fixation protein NifX stb) reprodukálhatóan sokkal kisebb mennyiségben detektáltuk a $6 \mathrm{~V}$ mutánsból, mint a vad-típusú növény gümőiböl. Az oldatban és a gélben emésztett minták összehasonlításából az is kitünik, hogy ez a két megközelítés nem könnyen állítható párhuzamba, inkább kiegészítheti egymást a további kutatásokban.

Összesen 139 NCR peptid azonosítottunk ezekben a kísérletekben. Ezeknek csaknem a felét kizárólag a vad típusú növény gümőiből sikerült kimutatni, míg egyetlen olyan NCR peptidet sem találtunk, ami kizárólag a mutáns növényre lett volna jellemző. Az első kísérlethez képest új NCR-eket is azonosítottunk. 
Munkánk harmadik részében az NCR247 peptid biológiai szerepére kerestünk választ lehetséges kölcsönható partnereinek azonosításával. Az NCR247 tulajdonságai (erős hidrofil karakter, extrém magas pI) miatt már korábban a Kondorosi-csoport érdeklődésének középpontjába került, több publikáció és doktori dolgozat bizonyította eme peptid antimikrobiális hatását különböző Gram-negatív és Gram-pozitív baktériumokkal és humán patogén gombafajokkal szemben. Transzkriptom-analízis eredményei alapján a peptid génje a gümőfejlödés korai szakaszában termelődik. Proteomikai vizsgálatainkhoz kémiailag szintetizált, diszulfid-hidakat nem tartalmazó peptidet használtunk (akárcsak a biológiai hatás tanulmányozásához), amelyet StrepII- vagy FLAG-taggel láttunk el a fehérje-komplexek könnyebb izolálása érdekében. S. meliloti (Sm1021) baktérium kultúrát és ezen baktériumok $M$. truncatula gümőiből izolált bakteroid formáit vizsgáltuk. In vitro kísérleteket végeztünk a megfelelő gyöngyre kötött peptiddel és a baktériumokból vagy bakteroidokból izolált fehérje-elegyekkel. Hét esetben baktériummal, egy esetben bakteroid mintával dolgoztunk, kontroll kísérletek elvégzésével. A baktérium-kultúrákból származó eredményeket összesítve azt kaptuk, hogy a lehetséges interakciós partnerek közül az azonosítások nagy hányadát a riboszómális fehérjék teszik ki, melyek 14 kis és 12 nagy alegységét azonosítottunk lehetséges kölcsönható partnerként. A riboszómális fehérjék mellett a GroEL bakteriális chaperon, piruvát dehidrogenáz-komplex, transzaldoláz, RNS-polimeráz béta és béta’ alegységei, elongációs faktorok és egyéb fehérjék is jelen voltak a mintában.

A bakteroidokban a GroEL és piruvát dehidrogenáz-komplex, kisebb mennyiségben riboszómális fehérjék kötődtek az NCR peptidhez. Bakteroid mintákban ezen kívül a nitrogenáz komplex elemeit, valamint NCR peptideket is azonosítottunk (NCR028, NCR169, NCR290). A baktérium és bakteroid mintákból származó lehetséges kölcsönható fehérjéket a jobb áttekinthetőség kedvéért funkcionális csoportokba soroltuk. Az NCR247-GroEL kölcsönhatást több oldalról is megvizsgálva (immuno-precipitációs kísérletek) egyértelművé vált, hogy az NCR247 kötődik a GroEL fehérjéhez, a két fehérje komplexet képez. Biológiailag releváns lehet az is, hogy az NCR247 kölcsönhatásba lép a nitrogén-fixálásban szerepet játszó fehérjékkel és más NCR peptidekkel, bár még nem tisztázott, hogy közvetlenül vagy más fehérjék közvetítésével teszi-e ezt. 


\section{Summary}

I have been studying symbiotic nodules during my $\mathrm{PhD}$ studies in the Proteomics Research Group. The relationship of legumes and endosymbiotic bacteria represents a scientifically exciting topic. Understanding the underlying processes may have medical and environmental significance.

In this study we focused on the detection of the nodule-specific cysteine-rich peptides (NCRs), the most important nodule-specific plant peptides (symPEPS) in the nitrogen-fixing symbiosis. The bacterial differentiation is controlled and regulated by these molecules. While expression of the NCR genes represents a major part of the nodule transcriptome, until now the existence of NCRs have not been validated at the peptide level. However, it has been reported by numerous groups that the relationship between the transcriptome and proteome is not straightforward. More than 500 genes code for nodule-specific cysteine rich (NCR) peptides in Medicago truncatula. However, we do not know how many NCR products really exist, what their turnover rate is and which of these peptides interact with and accumulate in the endosymbionts. Thus, our first aim was the large-scale detection of NCR peptides with mass spectrometry.

M. truncatula A17 Jemalong wild type plants were inoculated with Sinorhizobium medicae and S. meliloti bacteria. Experiments were performed with the indeterminant nodules of these plants. We also analyzed nodules of a mutant plant (6V) for nodule-specific NCR peptides.

Our aims were as follows:

1) The first aim of our examination was to detect these plant peptides in bacteroids, which regulate bacterial differentiation. Additionally we tried to validate signal peptide predictions, i.e. to determine the signal peptidase enzyme's processing sites in these NCRs.

2) We tried to decipher the biological functions of these peptides. Thus,

a) we attempted to determine differences between the NCR-contents in bacteroid populations at different developmental stages.

b) we compared the NCR-content of wild type and mutant plant nodules. The selected 
mutant has a well-defined phenotype.

c) We investigated what are the bacterial and plant protein targets of an NCR with verified antimicrobial effect and which bacterial functions are affected.

Obviously we had to establish and test adequate sample preparation methods. The high complexity of plant and bacterial proteins in the nodules might hinder the detection of NCR peptides. Thus, we tested the separation of bacterial and plant cells, and purification methods to isolate different bacteroid populations ("short" and Percoll-gradient purification). After cell lysis (that was also optimized) we tried to take advantage of NCR's special properties, such as small size and relatively high Cys-content in order to improve NCR-detection. This method development was accomplished with a bacteroid mixture. The accepted version of the workflow was adjusted to our specific aim: comparative protein analysis in different developmental stages and different genotypes.

Eventually the NCR-content of intact nodules, a mixture of bacteroids at various developmental stages and fully transformed bacteroids were examined.

We also performed a proteomic comparison between the wild type and $6 \mathrm{~V}$ mutant plant nodules. What makes the $6 \mathrm{~V}$ mutant interesting that it features nodules but it is still incapable for nitrogenfixation.

The Kondorosi-group has been studying the antimicrobial effects of NCR247 for several years. We tried to identify the potential protein targets of this NCR peptide. This research may shed light on the pathways through which this plant peptide influences the bacterial transformation.

\section{Results}

As the primary aim of this study, we focused on large-scale detection of NCR peptides with mass spectrometry. Three types of biological material were studied, based on the following assumptions. The root nodules are in principle the best suited for the identification of all expressed NCRs. However, the plant and bacterial protein background in nodules might hinder the detection of NCR peptides. Thus, the bacteroids were isolated using two purification 
protocols. The short one resulted in the isolation of a mixture of endosymbionts in all developmental stages, whereas the long one utilizing a Percoll gradient centrifugation enriched the terminally differentiated nitrogen-fixing bacteroids. Tryptic digestion was followed by automatic LC-MS/MS analysis and subsequent database search performed by Protein Prospector against two databases simultaneously, UniProt and our own database. Each digest was analyzed once, except the intact nodules where three technical replicates were performed from both samples.

Almost 300 proteins were identified from the combined data acquired from the intact nodule samples. More than half of these proteins derived from the plant, including 45 NCRs. The analysis of protein content of bacteroids in all developmental stages ('short purification') yielded approximately 600 proteins; more than $2 / 3$ of these originated from the bacteria, and $118 \mathrm{NCR}$ peptides were detected. Analysis of the 'mature' nitrogen-fixing bacteroids (Percoll-gradient purification) yielded 313 bacterial proteins and 103 M. truncatula proteins, including 75 NCR peptides.

Altogether, 138 NCRs were detected in these experiments. In order to identify potential differences in the NCR-content of the different bacteroid samples we performed an MS-based data comparison: a reference list was created from the merged search results, listing only the best CID data for each NCR sequence with the precursor's $\mathrm{m} / \mathrm{z}$ and the retention time. These data were compared to the reference list using the fitXIC program. An NCR entry was considered specific to a preparation if at least one tryptic peptide was detected in two of the biological replicates, while none was detected in the other preparation.

Twelve NCR peptides were only found in the 'short purification' mixture. We believe these peptides may be involved in the early stages of the bacteroid development. The 'Percoll purification' featured 5 NCR peptides. Some of these were classified as 'early stage' NCRs based on the transcriptome data. The persistence of these peptides suggests later or long term functional involvement in the endosymbionts.

In several NCRs we successfully identified the N-terminus of the mature peptide, thus, the cleavage site of the signal peptidase was identified/confirmed. 
Next we compared the proteome of wild type and 6V mutant nodules (inoculated with $S$. medicae). This mutant was selected because these plant-produce aberrant nodules in which bacteria are unable to fix nitrogen. The NCR169 gene is absent in this mutant, and this is the reason for the above mentioned defect. Thus, the changes in the proteome of the mutant nodules reflect the influence of this particular NCR. The protein content of bacteroid mixtures were compared, 3 biological replicates, with 3 technical replicates each. The workflow introduced in the earlier study was followed except for one sample we also performed protein-level fractionation on SDS-PAGE prior to the tryptic digestion and MS analysis. Quantitative data analysis was performed with spectral counting method. A $50 \%$ of change between the proteomes was considered significant. In mutant nodules, 16 proteins were present at higher levels (for example plant histone proteins) their significance requires further studies. Twenty three proteins were 'lost' or decreased in mutant samples. The plant protein content of this group was NCR and GRP peptides (symPEPs). Our result definitely reveals the defect of nitrogen-fixation on the proteome level in the M. truncatula $6 \mathrm{~V}$ mutant, because a series of proteins participating in this process, such as NifT/FixU family protein, Ferredoxin III 4(4Fe-4S) nif-specific, Nitrogenase protein, Nitrogen fixation protein NifX were detected at a significantly lower level than in the wild type plant. The in-solution and in-gel digestions produced slightly different results, indicating that although direct comparisons may not work, these methods could supplement each other.

Altogether, 139 NCR peptides were detected in this experiment, almost half of them were found just in the wild type nodules and none of them was unique for the mutant. Some NCR peptides were detected the first time.

Eventually we tried to decipher the biological role of NCR247 by identification of its potential interacting protein partners. This NCR was selected, because it showed antibiotic activity against some Gram-negative, Gram-positive and human pathogenic bacteria. Transcription analysis of NCR247 shows peptide production in the early stage of nodule development. Chemically synthetized NCR247 (without disulfide bonds) was used as bait for the protein-interaction analysis. The peptide was used with StrepII- and FLAG-tag for the easier isolation of the protein complexes. S. meliloti bacterial culture and bacteroids (from M. truncatula nodules) were studied (7 bacterial and one bacteroid sample was analyzed in parallel with control experiments, in vitro 
experiments). The potential targets from bacterial samples are: ribosomal proteins (14 and 12 proteins from the small and large subunits); bacterial chaperonin GroEL, pyruvate dehydrogenase complex, transaldolase, RNA polymerase subunit beta and beta', elongation factors and some other proteins.

In the bacteroid sample, GroEL and subunits of pyruvate dehydrogenase complex and ribosomal proteins were also detected as interacting partners. Additionally, units of the nitrogenase complex and NCR peptides (NCR028, NCR169, NCR290) were identified. The potential interacting partners from bacterial and bacteroid samples were grouped into functional categories for the better transparency.

The relevance of NCR247-GroEL relationship is still in question. This interaction has been confirmed by immuno-precipitation. Presently it is not clear whether the NCR247 directly interacts with proteins from the nitrogen-fixing pathway and with other NCR peptides or through intermediates. The significance of these interactions should be further investigated. 
9. Hivatkozások jegyzéke

1. ábra: Mierziak, J., Kostyn, K., Kulma, A. Flavonoids as important molecules of plant interactions with the environment. Molecules 2014, 19, 16240-162465.

2. ábra: http://5e.plantphys.net/article.php?ch=t\&id=155

4. ábra: Popp, C., Ott, T. Regulation of signal transduction and bacterial infection during root nodule symbiosis. 2011. Curr Opin Plant Biol. 2011 Aug;14(4):458-67

5. ábra: Mergaert P., Mikovics, K., Kelemen, Z., Maunoury, N. et al. A novel family in Medicago truncatula consisting of more than 300 nodule-specific genes coding for small, secreted polypeptides with conserved cysteine motifs. Plant Physiol 2003, 132, 161-173

7. ábra: www.lamondlab.com/MSResource/LCMS/MassSpectrometry/electrosprayIonisation.php

9. ábra: http://planetorbitrap.com/ltq-orbitrap-xl\#.VIG-X810ano

10. A ábra: http://www.ionsource.com/tutorial/DeNovo/nomenclature.htm

10. B ábra: http://www.weddslist.com/ms/tandem.html

15. ábra nés 16. ábra: Farkas, A., Maróti, G., Dürgő, H., Györgypál, Z., et al., The Medicago truncatula symbiotic peptide NCR27 contributes to bacteroid differentiation through multiple mechanisms. Proc Natl Acad Sci U S A. 2014, 111, 5183-5188. 